\title{
Initiation Temperature for Runaway Tri-n-Butyl Phosphate/Nitric Acid Reaction
}

by

T. S. Rudisill

Westinghouse Savannah River Company

Savannah River Site

Aiken, South Carolina 29808

W. J. Crooks III
DEC 042000

$0 S T_{1}$

This paper was prepared in connection with work done under the above contract number with the U.S. Department of Energy. By acceptance of this paper, the publisher and/or recipient acknowledges the U.S. Government's right to retain a nonexclusive, royalty-free license in and to any copyright covering this paper, along with the right to reproduce and to authorize others to reproduce all or part of the copyrighted paper. 


\section{DISCLAIMER}

This report was prepared as an account of work sponsored by an agency of the United States Government. Neither the United States Government nor any agency thereof, nor any of their employees, makes any warranty, express or implied, or assumes any legal liability or responsibility for the accuracy, completeness, or usefulness of any information, apparatus, product or process disclosed, or represents that its use would not infringe privately owned rights. Reference herein to any specific commercial product, process or service by trade name, trademark, manufacturer, or otherwise does not necessarily constitute or imply its endorsement, recommendation, or favoring by the United States Government or any agency thereof. The views and opinions of authors expressed herein do not necessarily state or reflect those of the United States Government or any agency thereof.

This report has been reproduced directly from the best available copy.

Available for sale to the public, in paper, from: U.S. Department of Commerce, National Technical Information Service, 5285 Port Royal Road, Springfield, VA 22161

phone: (800) 553-6847

fax: (703) 605-6900

email: orders@ntis.fedworld.gov

online ordering: http://www.ntis.gov/ordering.htm

Available electronically at $h$ ttp://www.doe.gov/bridge

Available for a processing fee to U.S. Department of Energy and its contractors, in paper, from: U.S. Department of Energy, Office of Scientific and Technical Information, P.O. Box 62, Oak Ridge, TN 37831-0062

phone: (865)576-8401

fax: (865)576-5728

email: reports@adonis.osti.gov 


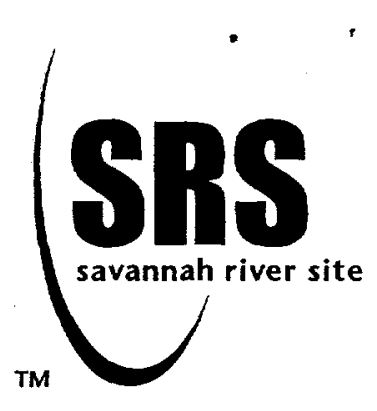

\section{WESTINGHOUSE SAVANNAH RIVER COMPANY INTEROFFICE MEMORANDUM}

October 31,2000

WSRC-TR-2000-00427-TL

TO: $\quad$ R. M. Mobley, NMSS Engineering, 703-F

FROM: A. L. Blancett Oreen De. Rlawau Actinide Technology Section, 773-A

\section{Transmittal Letter for WSRC-TR-2000-00427}

Please find attached the technical report Initiation Temperature for Runaway Tri-n-Butyl Phosphate/Nitric Acid Reaction (WSRC-TR-2000-00427). This work was performed in response to a DNFSB concern about the margin of safety associated with the initiation of a runaway tri-n-butyl phosphate (TBP)/nitric acid reaction in a canyon tank. To address this concern, the initiation temperature for runaway reaction was measured as functions of nitric acid and dissolved solids concentrations and compared to the minimum initiation temperature $\left(130^{\circ} \mathrm{C}\right)$ cited in the H-Canyon authorization basis. The experimental work demonstrated that the initiation temperature for TBP contacted with an aqueous solution containing no dissolved solids decreased with increasing acid concentration to a minimum of $137^{\circ} \mathrm{C}$, at $14-15 \mathrm{M}$ nitric acid. The initiation temperatures for TBP contacted with nitric acid solutions containing 5,10 , and $20 \mathrm{wt} \%$ dissolved solids showed a small dependence on the salt concentration; however, the lowest temperatures were several degrees above the minimum valued for no dissolved solids. The slight lowering of the initiation temperature was attributed to the increased extraction of nitric acid due to the salting-out effect of the dissolved solids.

CC: N. M. Askew, 773-A

N. E. Barnett, 707-F

A. L. Blancett, 773-A

T. G. Campbell, 221-F

M. C. Chandler, 704-2H

W. J. Crooks III, 773-A

W. G. Dyer, 704-2H

S. E. Federman, 221-H

F. R. Graham, 773-A

J. E. Laurinat, 773-A

M. J. Lewczyk, 704-2H
A. T. Johnson, 211-19H

D. R. Johnson, 704-2H

J. M. Low, 707-F

A. M. Murray, 773-A

L. D. Olson, 221-H

C. E. Pickett, 221-H

T. S. Rudisill, 773-A

M. C. Thompson, 773-A

J. C. Williams, 707-F

G. J. Winkler, 703-F

C. R. Wolfe, 773-A 


\section{DISCLAIMER}

Portions of this document may be illegible in electronic image products. Images are produced from the best available original document. 
WSRC-TR-2000-00427

Revision 0

\section{Initiation Temperature for Runaway \\ Tri-n-Butyl Phosphate/Nitric Acid Reaction}

Tracy S. Rudisill and William J. Crooks III

October 2000

Westinghouse Savannah River Company Aiken, SC 29808 
This page was intentionally left blank. 


\section{Table of Contents}

Section Page

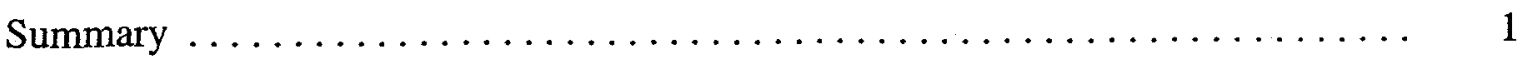

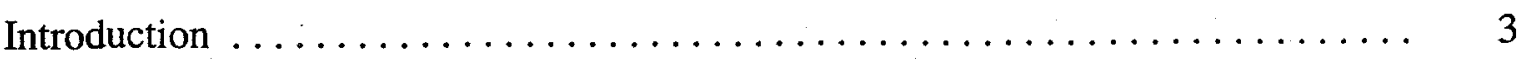

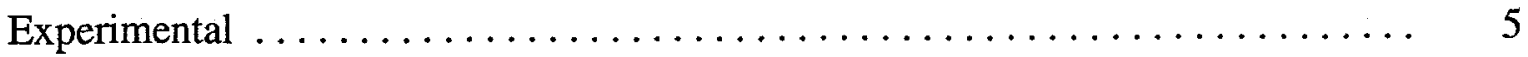

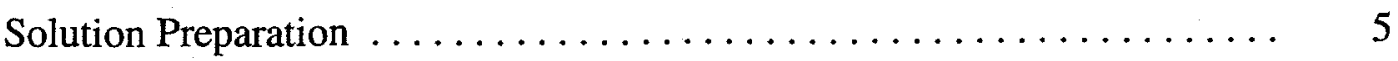

RSST $^{\mathrm{TM}}$ Operation $\ldots \ldots \ldots \ldots \ldots \ldots \ldots \ldots \ldots \ldots \ldots \ldots \ldots \ldots \ldots \ldots \ldots \ldots$

Extraction of Nitric Acid by TBP $\ldots \ldots \ldots \ldots \ldots \ldots \ldots \ldots \ldots \ldots \ldots$

Results and Discussion $\ldots \ldots \ldots \ldots \ldots \ldots \ldots \ldots \ldots \ldots \ldots \ldots$

Open RSST $^{\mathrm{rM}}$ Experiments $\ldots \ldots \ldots \ldots \ldots \ldots \ldots \ldots \ldots \ldots \ldots \ldots \ldots \ldots$

Closed RSST Experiments $\ldots \ldots \ldots \ldots \ldots \ldots \ldots \ldots \ldots \ldots$

Correlation of Initiation Temperature with Extracted Nitric Acid $\ldots \ldots \ldots \quad 11$ Concentration

Effect of Other Variables on Initiation Temperature $\ldots \ldots \ldots \ldots \ldots \ldots$

Nitrate Salt Solubility Limitations $\ldots \ldots \ldots \ldots \ldots \ldots \ldots \ldots \ldots$

Conclusions $\ldots \ldots \ldots \ldots \ldots \ldots \ldots \ldots \ldots \ldots \ldots \ldots \ldots \ldots \ldots \ldots \ldots \ldots \ldots$

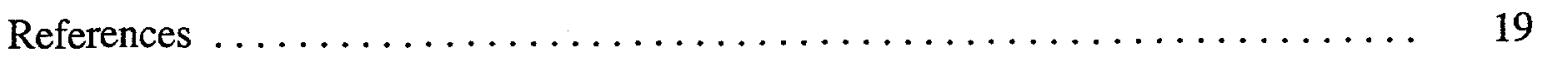




\section{List of Tables}

Page

Table 1 Initiation of Rapid Self-Heating for Open System Experiments $\ldots . .8$

Table 2 Runaway Reaction Initiation Temperatures for Closed System $\ldots \ldots \quad 10$ Experiments

Table 3 Nitric Acid Concentration in TBP Samples Used for RSST ${ }^{T M} \ldots \ldots$ Experiments

Table 4 Estimated Nitric Acid Concentration in TBP Samples Used for ... RSST $^{\mathrm{TM}}$ Experiments

Table $5 \quad$ Estimated Organic Phase Nitric Acid Concentrations for ........ Colven Data 


\section{List of Figures}

Figure 1 Colven Data - Initiation Temperature for Runaway TBP/Nitric ... Acid Reaction

Figure 2

RSST $^{\mathrm{TM}}$ Pressure Vesse

Figure 3 Temperature Profile and Self-Heating Rate for Open System .....

Run No. TBP 5/12-5

Figure 4 Temperature Profile and Self-Heating Rate for Open System .... Run No. TBP 5/12-6

Figure 5 Defining the Initiation Temperature for a Runaway TBP/Nitric $\ldots$ Acid Reaction

Figure 6

Effect of Acid Concentration and Solids Content on the Initiation Temperature for a Runaway TBP/Nitric Acid

Figure $7 \quad$ Regression Analysis for Runaway TBP/Nitric Acid Initiation ..... Temperature

Figure $8 \quad$ Extraction of Nitric Acid into Pure TBP $\ldots \ldots \ldots \ldots \ldots$

Figure 9 Correlation of Runaway Reaction Initiation with Extracted . . . . . Nitric Acid Concentration

Figure 10 


\section{List of Appendices}

Appendix A Reagent Data and Properties $\ldots \ldots \ldots \ldots \ldots \ldots \ldots \ldots \ldots \ldots$

Appendix B Preparation of TBP/Nitric Acid Solutions $\ldots \ldots \ldots \ldots \ldots \ldots \ldots$

Appendix C Temperature Profiles and Self-Heating Rates for Open $\ldots \ldots \ldots \ldots \quad 51$ RSST $^{\text {TM }}$ Experiments

Appendix D Temperature and Pressure Profiles for Closed RSST ${ }^{\mathrm{TM}} \ldots \ldots \ldots$ Experiments

Appendix E Preparation of Solutions for Nitric Acid Extraction 101 Measurements 


\title{
Initiation Temperature for Runaway Tri-n-Butyl Phosphate/Nitric Acid Reaction
}

\author{
Tracy S. Rudisill and William J. Crooks III \\ Westinghouse Savannah River Company \\ Savannah River Site \\ Aiken, SC 29808
}

\section{Summary}

During a review of the H-Canyon authorization basis, Defense Nuclear Facility Safety Board (DNFSB) staff members questioned the margin of safety associated with a postulated tri-n-butyl phosphate (TBP)/nitric acid runaway reaction due to the inadvertent heating of a canyon tank containing greater than $3000 \mathrm{lbs}(1362 \mathrm{~kg})$ of TBP. The margin of safety was partially based on experiments and calculations performed by the Actinide Technology Section (ATS) to support deletion of indication of tank agitation as a Safety Class System. In the technical basis for deletion of this system, ATS personnel conservatively calculated the equilibrium temperature distribution of a canyon tank containing TBP and nitric acid layers which were inadvertently heated by a steam jet left on following a transfer. The maximum calculated temperature $\left(128^{\circ} \mathrm{C}\right)$ was compared to the minimum initiation temperature for a runaway reaction (greater than $130^{\circ} \mathrm{C}$ ) documented by experimental work in the mid 1950's. In this work, the initiation temperature as a function of nitric acid concentration was measured for 0 and $20 \mathrm{wt} \%$ dissolved solids. The DNFSB staff members were concerned that data for $0 \mathrm{wt} \%$ dissolved solids were not conservative given the facts that data for $20 \mathrm{wt} \%$ dissolved solids show initiation temperatures at or below $130^{\circ} \mathrm{C}$ and $\mathrm{H}$-Canyon solutions normally contained a small amount of dissolved solids.

To address the DNFSB concern, the initiation temperature for a runaway TBP/nitric acid reaction was measured as functions of the nitric acid and dissolved solids concentration of the aqueous phase in equilibrium with pure TBP. Initiation temperatures were measured using a Reactive System Screening Tool $^{\mathrm{TM}}$ (RSST ${ }^{\mathrm{TM}}$ ), a nearly adiabatic calorimeter equipped with temperature and pressure monitoring capability. Initially, experiments were performed with the RSST ${ }^{\text {TM }}$ open to atmospheric pressure; however, the self-heating rate was not sufficient for runaway reaction to occur. This observation is consistent with the result from previous studies which showed that adequate vessel venting is the first defense against a damaging runaway reaction.

To obtain a runaway TBP/nitric acid reaction, it was necessary to seal the RSST ${ }^{\mathrm{TM}}$ containment vessel at atmospheric pressure prior to the initiation of an experiment. Without adequate venting, self-heating from the oxidation of TBP degradation products was sufficient for runaway reaction to occur. The runaway reaction initiation temperature was defined by the time and corresponding temperature when a rapid increase in the vessel pressure was initially seen. 
The runaway reaction initiation temperatures for TBP contacted with nitric acid solutions containing no dissolved solids were in good agreement with data from the 1950's. The initiation temperature gradually decreased with increasing aqueous phase nitric acid concentration due to the increase in the available oxidant (nitric acid) extracted by the TBP. The minimum initiation temperature, $137^{\circ} \mathrm{C}$, measured at $14-15 \mathrm{M}$ nitric acid was consistent with previously measured values $\left(132-137^{\circ} \mathrm{C}\right)$ at nominally $15.7 \mathrm{M}$ nitric acid. The initiation temperatures measured using TBP contacted with nitric acid solutions containing 5, 10, and $20 \mathrm{wt} \%$ dissolved solids showed a small dependence on the salt concentration; however, the lowest temperatures were several degrees above the minimum value for no dissolved solids. The slight lowering of the initiation temperature was attributed to the increased extraction of nitric acid due to the salting-out effect of the dissolved solids.

The results of the closed RSST $\mathrm{T}^{\mathrm{TM}}$ experiments demonstrated that the initiation temperature for a runaway TBP/nitric acid reaction decreased with the amount of nitric acid extracted by the TBP. To illustrate this point, a correlation of the initiation temperature as a function of the extracted nitric acid concentration was developed by analyzing or estimating the amount of nitric acid extracted into the TBP samples used for each RSST ${ }^{T M}$ experiment. When plotted, the initiation temperature decreased linearly with increasing nitric acid concentration. An increase in the TBP nitric acid concentration results in a faster reaction (oxidation) rate at a lower temperature which reduces the temperature where runaway reaction occurs. The correlation also illustrated that initiation temperatures measured previously using TBP contacted with an aqueous phase containing $8-10 \mathrm{M}$ nitric acid and $20 \mathrm{wt} \%$ sodium and/or potassium nitrate $\left(\mathrm{Na} / \mathrm{KNO}_{3}\right)$ are 10 $15^{\circ} \mathrm{C}$ below expected values based on a linear regression used to correlate the data.

RSST $^{\mathrm{TM}}$ experiments were performed to look at the effect of other variables (nitrate salt and number of phases) on the initiation temperature for a runaway TBP/nitric acid reaction. Several experiments were performed in which the dissolved solids were changed from aluminum nitrate $\left(\mathrm{Al}\left(\mathrm{NO}_{3}\right)_{3}\right)$ to $\mathrm{NaNO}_{3}$, or $\mathrm{KNO}_{3}$. No significant effect on the initiation temperature was seen. RSST $^{\mathrm{TM}}$ experiments were also performed to evaluate the effect of additional phases (aqueous and solid) on the thermal behavior of the TBP samples. Neither the presence of the aqueous phase originally used to contact the TBP nor a small amount of undissolved solids in the aqueous phase had a significant effect on the runaway reaction initiation temperature. The only noticeable difference in thermal behavior was the extended time required to evaporate the aqueous phase prior to runaway reaction occurring. 


\section{Introduction}

During a review of the $\mathrm{H}$-Canyon Authorization Basis, Defense Nuclear Facility Safety Board (DNFSB) staff members questioned the margin of safety associated with a postulated tri-n-butyl phosphate (TBP)/nitric acid runaway reaction due to the inadvertent heating of a canyon tank containing greater than $3000 \mathrm{lbs}(1362 \mathrm{~kg})$ of TBP. The margin of safety was partially based on experiments and calculations performed by the Actinide Technology Section (ATS) to support deletion of indication of tank agitation as a Safety Class System. In the technical basis for deletion of this system, ATS personnel conservatively calculated the equilibrium temperature distribution of a canyon tank containing TBP and nitric acid layers which were inadvertently heated by a steam jet left on following a transfer.[1] The maximum calculated temperature $\left(128^{\circ} \mathrm{C}\right.$ ) was compared to the minimum initiation temperature for a runaway reaction (greater than $130^{\circ} \mathrm{C}$ ) measured by Colven in the mid 1950's. [2] In this work, the initiation temperature as a function of nitric acid concentration was measured for 0 and $20 \mathrm{wt} \%$ dissolved solids (see Figure 1). The DNFSB staff members were concerned that data for $0 \mathrm{wt} \%$ dissolved solids were not conservative given the facts that data for $20 \mathrm{wt} \%$ dissolved solids show initiation temperatures below $130^{\circ} \mathrm{C}$ and $\mathrm{H}$-Canyon solutions normally contained a small amount of dissolved solids.

To address the DNFSB concern, the initiation temperature for a runaway $\mathrm{TBP} /$ nitric acid reaction was measured as functions of the nitric acid and dissolved metal nitrate salt concentrations of the aqueous phase in equilibrium with pure TBP. Only the organic phase was used for the experiments due to the cooling mechanism provided by water, nitric acid, and volatile components produced by the degradation of the TBP. Smith et. al.[3] showed that the forced evaporation of the volatile components by noncondensible product gases during the oxidation of TBP degradation products resulted in a cooling mechanism which more than balanced the heat from oxidation. As long as the TBP was in contact with an aqueous phase, water, the main coolant in the organic phase, was replenished by interfacial mixing by gas produced from oxidation in the aqueous phase. The results from Smith's experiments were applied to canyon evaporator operation just after shutdown when enough nitric acid-soluble organic material would be present in the aqueous phase to generate the bubbling required for mixing; however, Laurinat et. al.[1] showed that mixing in a canyon tank was sufficient to replenish water extracted by the TBP and runaway reaction would not occur. Although 7.5 and 30 vol\% TBP diluted by a normal paraffin (n-paraffin) are used as solvents in H-Canyon,[4] only pure TBP was used for the runaway reaction experiments. Dilution of the TBP with the n-paraffin would only provide another volatile component of the solvent which must evaporate before runaway reaction occurs.

The dissolved solids used by Colven to measure the runaway reaction initiation temperatures for $20 \mathrm{wt} \%$ dissolved solids were either sodium or potassium nitrate $\left(\mathrm{NaNO}_{3}\right.$ or $\left.\mathrm{KNO}_{3}\right)$ or a combination of the two salts. [2] For this study, aluminum nitrate $\left(\mathrm{Al}\left(\mathrm{NO}_{3}\right)_{3}\right)$ was selected as the dissolved metal nitrate salt for the majority of the experiments for its ability to increase the extraction of nitric acid by a "salting-out effect." When a salting agent is added to the aqueous phase, extraction of nitric acid is enhanced by a combination of effects. The higher concentration of nitrate anions improves extraction by mass action. The activity of the nitric acid also increases 
due to complexation of water by aluminum which then becomes unavailable as "free solvent."[5] The effectiveness of $\mathrm{Al}\left(\mathrm{NO}_{3}\right)_{3}$ as a salting agent should be better than the monovalent cations based on the size of the hydrated ion and known hydration number ( 6 versus 4 for $\mathrm{NaNO}_{3}$ and $\mathrm{KNO}_{3}$ ).[6,7] Thompson [6] has demonstrated that $\mathrm{Al}\left(\mathrm{NO}_{3}\right)_{3}$ was a much better salting agent than $\mathrm{NaNO}_{3}$ for nitric acid and selected lanthanide and actinide elements. 


\section{Experimental}

\section{$\underline{\text { Solution Preparation }}$}

Reagent grade TBP, nitric acid, and $\mathrm{Al}\left(\mathrm{NO}_{3}\right)_{3}, \mathrm{NaNO}_{3}$, and $\mathrm{KNO}_{3}$ salts were used to prepare the solutions for the runaway reaction experiments. Information concerning the reagent manufacturer, lot number, and purity is provided in Appendix A. The concentration and density of the nominally $70 \mathrm{wt} \%$ nitric acid used in the experiments were measured to ensure accurate dilutions were made during the preparation of the aqueous phase solutions for the experiments. The concentration and density measurements are summarized in Appendix A (see Tables A.1 and A.2, respectively).

The TBP used in the runaway reaction studies was prepared by contacting one volume $(12 \mathrm{~mL})$ of organic with 5 volumes $(60 \mathrm{~mL})$ of aqueous to ensure the maximum extraction of nitric acid. The aqueous solutions were prepared by transferring the target mass of the metal nitrate salt to a $200 \mathrm{~mL}$ beaker. The target masses of deionized water and nominally $70 \mathrm{wt} \%$ nitric acid were then added in succession. The mass of nitric acid required to prepare the diluted nitric acid solutions was calculated using nitric acid densities reported by Davis et. al.[9] at $25^{\circ} \mathrm{C}$ (Appendix A, Table A.3) and the measured concentration of the starting reagent. The temperature of the laboratory used to prepare the solutions was $25 \pm 5^{\circ} \mathrm{C}$. Following the addition of all reagents, the metal nitrate salts were dissolved by stirring with a magnetic stir bar. For aqueous solutions containing metal nitrate salt concentrations approaching the solubility limit, it was necessary to slightly heat the solution in order to obtain complete dissolution. When heating was necessary, a watch glass containing water was placed on the beaker to slow evaporation. After dissolution, a disposable transfer pipette was used to rinse condensate from the bottom of the watch glass back into the beaker with an aliquot of the solution.

\section{$\underline{\text { RSST TM }^{\mathrm{T}} \text { Operation }}$}

The initiation temperatures for runaway TBP/nitric acid reactions were measured using a Reactive System Screening Tool ${ }^{\mathrm{TM}}$.(RSST ${ }^{\mathrm{TM}}$ ) manufactured by Fauske and Associates, Inc:[8] The RSST ${ }^{\mathrm{TM}}$ is a nearly adiabatic calorimeter equipped with temperature and pressure sensors to allow real time data monitoring and acquisition. A well insulated, $10 \mathrm{~mL}$ test cell is fitted with a small heater which allows heating of the contents at a controlled rate. The test cell is normally sealed within a high pressure containment vessel (see Figure 2) that serves as both a pressure simulator and a safety vessel; however, the TBP/nitric acid experiments were either performed at atmospheric pressure in a well vented system or the containment vessel was sealed at atmospheric pressure at the beginning of the experiment. The runaway reaction initiation temperature was determined for closed vessel experiments by monitoring the temperature of the TBP and pressure of the RSST ${ }^{\mathrm{TM}}$ safety vessel as functions of time.

To perform an RSST $\mathrm{T}^{\mathrm{TM}}$ experiment, a $10 \mathrm{~mL}$ aliquot of TBP previously contacted with a nitric acid solution was transferred to a new RSST ${ }^{\mathrm{TM}}$ test cell. The mass of TBP was determined by difference using the premeasured mass of the test cell. A small magnetic stirrer was added to the 
test cell to provide stirring during the experiment. The RSST ${ }^{\mathrm{rm}}$ was then assembled and the experiment initiated by computer control. As noted above, RSST ${ }^{\mathrm{TM}}$ experiments were performed at atmospheric pressure using a well vented (open) safety vessel or after sealing the safety vessel at atmospheric pressure. Upon initiation of an experiment, the RSST ${ }^{\mathrm{TM}}$ control system increased the temperature of the TBP at nominally $1^{\circ} \mathrm{C} / \mathrm{min}$. The temperature of the TBP and the pressure inside the RSST ${ }^{\mathrm{TM}}$ (for closed system experiments) were recorded as functions of time by the data acquisition system. The RSST ${ }^{\mathrm{TM}}$ experiments were terminated when the temperature of the TBP reached $200^{\circ} \mathrm{C}$ by turning off the cell heater. The temperature/pressure data were then processed to generated plots of temperature versus time, pressure versus time, self-heating rate versus temperature, and rate of pressure change versus temperature which were used to evaluated the thermal stability of the TBP sample.

\section{Extraction of Nitric Acid by TBP}

After initiation of the RSST ${ }^{\mathrm{TM}}$ experiments, it became apparent that knowing the amount of nitric acid extracted by the TBP would be useful in correlating the runaway reaction initiation temperatures. To obtain these data, duplicate $1 \mathrm{~mL}$ samples of TBP were titrated with base to obtain the amount of nitric acid extracted during contact with the aqueous phase.

In order to obtain an estimate of the nitric acid extracted by TBP samples which were not analyzed, a series of extractions were preformed in which pure TBP was contacted with nitric acid solutions containing 5,10, and $20 \mathrm{wt} \% \mathrm{Al}\left(\mathrm{NO}_{3}\right)_{3}$. The nitric acid concentrations used for each concentration of $\mathrm{Al}\left(\mathrm{NO}_{3}\right)_{3}$ ranged from $4 \mathrm{M}$ to a concentration just below the point where crystallization was seen $\left(12,10\right.$, and $8 \mathrm{M}$ for 5,10 , and $20 \mathrm{wt} \% \mathrm{Al}\left(\mathrm{NO}_{3}\right)_{3}$, respectively). The aqueous phase and TBP were prepared in the same manner as the solutions used for the RSST ${ }^{\mathrm{TM}}$ experiments. Three $1 \mathrm{~mL}$ samples of TBP were analyzed by titration to obtain the amount of nitric acid extracted. The data generated by these analyses were used to predict the amount of nitric acid extracted by the TBP used for the remainder of the RSST ${ }^{\mathrm{TM}}$ experiments. 


\section{Results and Discussion}

\section{Open RSST TM Experiments}

The initial experiments to measure the initiation temperature for a runaway TBP/nitric acid reaction were performed with the RSST ${ }^{\mathrm{TM}}$ open to atmospheric pressure. This approach was used to model the well-vented tanks in $\mathrm{F}$ and $\mathrm{H}$-Canyons without excessive conservatism. The energy released by the oxidation of TBP degradation products is a strong function of pressure. TBP degradation products such as butanol and butyl nitrate are volatile and their removal from the RSST $^{\mathrm{TM}}$ test cell would limit the available energy release. A closed system which leads to increased pressure also inhibits the cooling mechanism provided by the forced evaporation of water and other volatile species from the TBP.[3]

Open RSST ${ }^{\mathrm{TM}}$ experiments were performed at 0 and $5 \mathrm{wt} \%$ dissolved solids $\left(\mathrm{Al}\left(\mathrm{NO}_{3}\right)_{3}\right.$ and $\mathrm{NaNO}_{3}$ ) using nitric acid concentrations ranging from 2 to $15 \mathrm{M}$. A summary of the reagent masses used to prepare the aqueous and organic phases and resulting concentrations for each run is provided in Appendix B (see Table B.1). For the open system experiments, the self-heating rate from the oxidation of TBP degradation products was used to define the runaway reaction initiation temperature. The initiation temperature was defined as the temperature of the TBP when the self-heating rate diverged from the imposed heat-up rate of $1^{\circ} \mathrm{C} / \mathrm{min}$. The temperature profiles (i.e. temperature versus time data) and self-heating rates as a function of TBP temperature for the open system experiments are presented in Appendix C.

The self-heating rate curves generally reflected the imposed heat-up rate of $1^{\circ} \mathrm{C} / \mathrm{min}$ until about $115-120^{\circ} \mathrm{C}$ when cooling from the evaporation of water and nitric acid from the TBP resulted in a noticeable decrease in the self-heating rate. Once water, the primary coolant evaporated, the self-heating rate increased substantially above $1^{\circ} \mathrm{C} / \mathrm{min}$; at that point, the initiation temperature was defined. The initiation temperatures measured in this manner are summarized in Table 1 as a function of the nitric acid and $\mathrm{Al}\left(\mathrm{NO}_{3}\right)_{3} / \mathrm{NaNO}_{3}$ concentrations.

The runaway reaction initiation temperature should decrease as the nitric acid concentration of the aqueous phase (which has contacted the TBP) increases. This is consistent with the initiation temperatures measured by Colven [2] and would be expected since the nitric acid available to oxidize TBP degradation products increases with the nitric acid concentration of the aqueous phase (see Appendix A, Table A.3). However, the data presented in Table 1 are not in agreement with the expected behavior. The initiation temperature for runaway reaction is generally lower for TBP contacted with lower concentrations of nitric acid. Based on this observation, two (open system) RSST ${ }^{\mathrm{M}}$ experiments were designed to determine if conditions approaching a runaway reaction actually occurred in the RSST ${ }^{\mathrm{TM}}$ test cell. In these experiments the TBP temperature was increased in a step-wise fashion until $200^{\circ} \mathrm{C}$ was reached. When the intermediate temperatures were attained, the RSST ${ }^{\mathrm{TM}}$ heater was shutdown to determine if the self-heating rate was sufficient for runaway reaction to occur. The temperature profiles and self-heating rates for the two experiments are shown on Figures 3 and 4. 
Table 1 Initiation of Rapid Self-Heating for Open System Experiments

\begin{tabular}{lccc}
\hline \hline Run No. & $\begin{array}{c}\text { Nitric Acid } \\
\text { Concentration } \\
\text { (moles/L) }\end{array}$ & $\begin{array}{c}\mathrm{Al}\left(\mathrm{NO}_{3}\right)_{3} \\
\text { Concentration } \\
(\mathrm{wt} \%)\end{array}$ & $\begin{array}{c}\text { Initiation } \\
\text { Temperature } \\
\left({ }^{\circ} \mathrm{C}\right)\end{array}$ \\
\hline TBP 0/2-1 & 2 & 0 & 123 \\
TBP 0/8-1 & 8 & 0 & 130 \\
TBP 0/15-1 & 15 & 0 & 134 \\
TBP 5/4-1 & 4 & 5 & 125 \\
TBP 5/4-2 & 4 & 5 & 131 \\
TBP 5/4-3 & 4 & 5 & 120 \\
TBP 5/4-4 & 4 & 5 & 124 \\
TBP 5/6-1 & 6 & 5 & 137 \\
TBP 5/12-1 & 12 & 5 & 135 \\
TBP 5/12-2 & 12 & 5 & 134 \\
\hline
\end{tabular}

(1) Initiation temperature was defined by the TBP temperature when the self-heating rate diverged from the achieved heat-up rate of approximately $0.35^{\circ} \mathrm{C} / \mathrm{min}$.

(2) $\mathrm{NaNO}_{3}$ used as Dissolved Solid

The temperature profile for each RSST ${ }^{\mathrm{TM}}$ experiment shows that the temperature of the TBP began to decrease immediately after the heater was shutdown at each intermediate temperature. A self-heating rate sufficient for runaway reaction to occur in the RSST ${ }^{\mathrm{TM}}$ test cell was not attained. This observation reinforces the results of previous studies which have shown that adequate venting of vessels is the first defense against a damaging runaway reaction.[10] Fauske and Associates demonstrated that a vent area of $0.063 \mathrm{~mm}^{2}$ per gram of TBP was sufficient to reduce the overpressure from a runaway reaction to less than $2 \mathrm{psi}(13,789 \mathrm{~Pa})$. The TBP used for the Fauske experiment was previously contacted with $15 \mathrm{M}$ nitric acid as a worst case condition.[11] The RSST ${ }^{\mathrm{TM}}$ used for the open system experiments was vented through a Whitey ${ }^{\circledR}$ ball valve (catalog no. SS-42F2) with a $3.2 \mathrm{~mm}$ orifice. The maximum mass of TBP used during an open system experiment was $11.04 \mathrm{~g}$ (see Appendix B, Table B.3) which corresponded to an aqueous phase containing $15 \mathrm{M}$ nitric acid. The calculated vent area is 0.73 $\mathrm{mm}^{2}$ per gram of TBP; therefore, the RSST ${ }^{\mathrm{TM}}$ was a well vented vessel based on the work by Fauske and Associates and a runway reaction would not be expected to occur.

\section{Closed RSST ${ }^{\mathrm{TM}}$ Experiments}

To obtain a runway TBP/nitric acid reaction, it was necessary to seal the RSST ${ }^{\mathrm{TM}}$ safety vessel at atmospheric pressure prior to the initiation of an experiment. Without adequate venting, selfheating from the oxidation of TBP degradation products was sufficient for runaway reaction to occur. At the point of runaway, both rapid increases in the RSST ${ }^{\mathrm{TM}}$ safety vessel pressure and TBP temperature were seen. Measuring the initiation temperature for runaway reaction in a closed vessel like the RSST ${ }^{\top M}$ is consistent with the approached used by Colven.[2] In earlier experiments, Colven et. al.[12] used a sealed $1 \mathrm{~L}$ test vessel to measure the initiation temperature 
for spontaneous reaction in a two phase system containing TBP and highly concentrated (38-85 wt\%) uranyl nitrate in dilute (1-4 wt\%) nitric acid solution.

Closed RSST ${ }^{\mathrm{TM}}$ experiments were performed at $0,5,10$, and $20 \mathrm{wt} \%$ dissolved solids $\left(\mathrm{Al}\left(\mathrm{NO}_{3}\right)_{3}\right.$, $\mathrm{NaNO}_{3}$, and $\mathrm{KNO}_{3}$ ) using nitric acid concentrations ranging from 4 to $12 \mathrm{M}$. A summary of the reagent masses used to prepare the aqueous and organic phases and resulting concentrations and mass of equilibrated TBP added to the RSST ${ }^{\mathrm{TM}}$ test cell for each run is provided in Appendix B (see Tables B.2 and B.4, respectively). The runaway reaction initiation temperature for the closed experiments was defined by the time period when a rapid increase in the pressure of the RSST $^{\mathrm{TM}}$ safety vessel was initially seen. The procedure for defining the initiation temperature is illustrated on Figure 5. Using the pressure profile of the safety vessel (i.e. pressure versus time data), the time of the initial pressure spike is noted; the initiation temperature (or temperature range) is then determined from the corresponding temperature versus time data. In a majority of the experiments, the time of the initial pressure spike corresponded to a range of temperatures since the TBP temperature was rapidly increasing due to the excessive self-heating. When this behavior was seen, the average of the temperature range was designated the runaway reaction initiation temperature. Plots of the temperature and pressure profiles for each of the closed RSST $^{\mathrm{TM}}$ experiments are presented in Appendix D. The results of this analysis for each successful experiment is summarized in Table 2.

The use of the rapid rise in the RSST ${ }^{\mathrm{TM}}$ safety vessel pressure to define the runaway reaction initiation temperature worked well except for experiments performed with TBP contacted with aqueous solutions containing high concentrations (13-15M) of nitric acid. In these experiments, a gradual increase in the system pressure, well before runaway reaction occurred, obscured the point of initiation. The increase in pressure can be attributed to the evaporation of both water and nitric acid. Evaporation of nitric acid extracted by the TBP is likely the key contributor to the initial pressure rise for these experiments. For TBP contacted with an aqueous solution containing 13-15M nitric acid, the extracted nitric acid approaches 5-6M (see Appendix A, Table A.3). To define the runaway reaction initiation temperature for these experiments, it was necessary to compare both the temperature and pressure profiles from the experiment to ensure that rapid increases in both temperature and pressure were occurring at the same time.

In order to compare the initiation temperatures for a runaway $\mathrm{TBP} /$ nitric acid reaction measured by Coven [2] and the data presented in Table 2, the initiation temperature as functions of nitric acid and dissolved solids concentrations for both data sets are plotted on Figure 6 . Only the linear regression line for the Colven data at $0 \mathrm{wt} \%$ dissolved solids is shown to reduce the number of data points which facilitates the comparison. Inspection of the data on Figure 6 shows that there is good agreement between both data sets at $0 \mathrm{wt} \%$ dissolved solids with the initiation temperature gradually decreasing with increasing nitric acid concentration. The decrease in the initiation temperature is due to the increase in the available oxidant (nitric acid) extracted by the 
WSRC-TR-2000-00427

Revision 0

Table 2 Runaway Reaction Initiation Temperature for Closed System Experiments

\begin{tabular}{lccccc}
\hline \hline Run No. & \multicolumn{2}{c}{ Aqueous Concentration } & Initiation & Initiation \\
& $\begin{array}{c}\text { Nitric Acid } \\
(\text { moles/L) }\end{array}$ & $\begin{array}{c}\text { Time } \\
(\text { wt } \%)\end{array}$ & $\begin{array}{c}\text { Ave Initiation } \\
\text { (min) }\end{array}$ & $\begin{array}{c}\text { Temp Range } \\
\left({ }^{\circ} \mathrm{C}\right)\end{array}$ & $\begin{array}{c}\text { Temperature } \\
\left({ }^{\circ} \mathrm{C}\right)\end{array}$ \\
\hline TBP 0/4-3 & 4.00 & 0 & 124 & $155-159$ & 157 \\
TBP 0/8-2 & 8.00 & 0 & $101-103$ & $149-152$ & 150.5 \\
TBP 0/8-3 & 8.00 & 0 & 162 & $151-155$ & 153 \\
TBP 0/10-1 & 10.00 & 0 & 127 & $143-145$ & 144 \\
TBP 0/12-1 & 12.00 & 0 & 132 & 139 & 139 \\
TBP 0/13-1 & 13.00 & 0 & 153 & $141-143$ & 142 \\
TBP 0/14-1 & 14.00 & 0 & 126.4 & 137 & 139.5 \\
TBP 0/15-2 & 14.99 & 0 & 129.5 & 139 & 139 \\
TBP 0/15-3 & 15.00 & 0 & 175 & $134-140$ & 137 \\
TBP 5/4-7 & 4.00 & 5.00 & 128 & $155-159$ & 157 \\
TBP 5/4-8 & 4.00 & 5.00 & 120 & $153-156$ & 154.5 \\
TBP 5/6-2 & 6.00 & 5.00 & 124 & $149-152$ & 150.5 \\
TBP 5/8-1 & 8.00 & 5.00 & 130 & $145-147$ & 146 \\
TBP 5/8-2 & 8.00 & 5.02 & 108 & $147-149$ & 148 \\
TBP 5/10-1 & 10.00 & 5.00 & 137 & 143 & 143 \\
TBP 5/12-3 & 11.99 & 5.00 & 138 & 139 & 139 \\
TBP 5/12-4 & 12.00 & 5.01 & 133 & $139-140$ & 139.5 \\
TBP 10/4-1 & 4.00 & 10.01 & 124 & $151-154$ & 152.5 \\
TBP 10/4-2 & 4.00 & 10.00 & 130 & $155-156$ & 155.5 \\
TBP 10/6-1 & 6.00 & 10.01 & 112 & $148-151$ & 149.5 \\
TBP 10/8-1 & 8.00 & 10.01 & 111 & $146-148$ & 147 \\
TBP 10/8-2 & 8.00 & 10.01 & 117 & 147 & 147 \\
TBP 10/9-1 & 8.99 & 10.01 & 107 & $147-149$ & 148 \\
TBP 10/10-1 & 10.00 & 10.00 & 119 & $145-147$ & 146 \\
TBP 10/10-2 & 10.00 & 10.00 & 115 & $145-147$ & 146 \\
TBP 20/4-1 & 4.00 & 20.00 & 135 & $147-150$ & 148.5 \\
TBP 20/4-2 & 4.00 & 19.99 & 128 & $154-158$ & 156 \\
TBP 20/6-1 & 6.00 & 20.00 & 134 & $148-150$ & 149 \\
TBP 20/6-2 & 6.00 & 20.00 & 114 & $151-154$ & 152.5 \\
TBP 20/6-3 & 6.00 & 19.99 & 108 & $146-149$ & 147.5 \\
TBP 20/7-1 & 7.00 & 20.00 & 255 & $139-140$ & 139.5 \\
TBP 20/7-3 & 7.00 & 20.00 & 108 & $149-151$ & 150 \\
TBP 20/7-4 & 7.00 & 20.00 & 114 & $146-150$ & 148 \\
TBP 20/8-1 & 8.00 & 20.00 & 123 & $146-149$ & 147.5 \\
\hline & & & & &
\end{tabular}

(1) Two Phase Experiment

(2) Initiation Temperature Based on Temperature Spike at $125.4 \mathrm{~min}$

(3) $\mathrm{NaNO}_{3}$ used as Dissolved Solid

(4) Three Phase Experiment

(5) $\mathrm{KNO}_{3}$ used as Dissolved Solid 
TBP. The minimum measured initiation temperature, $137^{\circ} \mathrm{C}$, measured at $14-15 \mathrm{M}$ nitric acid is consistent with the values $\left(132-137^{\circ} \mathrm{C}\right)$ measured by Colven at nominally $15.7 \mathrm{M}$ nitric acid. The initiation temperatures measured using TBP contacted with nitric acid solutions containing 5,10 , and $20 \mathrm{wt} \%$ dissolved solids show a small dependence on the salt concentration. This effect is more clearly seen on Figure 7 where linear regression lines were plotted instead of the actual data points.

\section{Correlation of Initiation Temperature with Extracted Nitric Acid Concentration}

The decrease in the runaway reaction initiation temperature with increasing dissolved solids content can be attributed to the increased extraction of nitric acid due to the salting-out effect. To illustrate this point, duplicate samples of the TBP used to perform a majority of the RSST ${ }^{\mathrm{TM}}$ experiments were analyzed for free acid to determine the amount of nitric acid which was extracted into the TBP. The results of these analyses and the corresponding runaway reaction initiation temperature are presented in Table 3.

To obtain an estimate of the nitric acid extracted by the TBP used in RSST ${ }^{\mathrm{TM}}$ experiments for which samples were not analyzed, a series of extractions were performed in which pure TBP was contacted with nitric acid solutions containing 5, 10, and $20 \mathrm{wt} \% \mathrm{Al}\left(\mathrm{NO}_{3}\right)_{3}$. The reagent masses used to prepare the aqueous and organic phases and resulting concentrations and free acid analyses for triplicate samples of the organic phase are provided in Appendix E (see Tables E.1 and E.2, respectively). The free acid analyses were used to correlate the amount of nitric acid extracted into the organic phase with the concentrations of nitric acid and $\mathrm{Al}\left(\mathrm{NO}_{3}\right)_{3}$ in the aqueous phase. The correlations including data reported by Davis et. al.[9] for pure TBP contacted with various concentrations of pure nitric acid solution are presented on Figure 8 . The data reported by Davis (see Appendix A, Table A.3) were based on experimentally determined values which were empirically smoothed to reduce scatter.

From inspection of Figure 8, one can see that the addition of $\mathrm{Al}\left(\mathrm{NO}_{3}\right)_{3}$ to the various nitric acid solutions did not have a measurable effect on the concentration of nitric acid in the organic phase until the aqueous phase contained $20 \mathrm{wt} \% \mathrm{Al}\left(\mathrm{NO}_{3}\right)_{3}$. This is surprising given the small, but, measurable decrease in the runway reaction initiation temperature seen with TBP contacted with nitric acid solutions containing 5 and $10 \mathrm{wt} \% \mathrm{Al}\left(\mathrm{NO}_{3}\right)_{3}$. It is possible that the analytical technique was not sensitive enough to resolve the difference between the amount of nitric acid extracted from the aqueous phase below $20 \mathrm{wt} \% \mathrm{Al}\left(\mathrm{NO}_{3}\right)_{3}$. Since the nitric acid concentrations for the TBP contacted with acid solutions containing 5 and $10 \mathrm{wt} \% \mathrm{Al}\left(\mathrm{NO}_{3}\right)_{3}$ differed little from the data reported by Davis, the smoothed data were used to estimate the concentration of nitric acid in the TBP samples contacted with aqueous phases containing 0,5 , and $10 \mathrm{wt} \%$ dissolved solids. For experiments performed with an aqueous phase containing $20 \mathrm{wt} \% \mathrm{Al}\left(\mathrm{NO}_{3}\right)_{3}$, the measured values were used to estimate the amount of extracted nitric acid. The estimated concentrations and the corresponding runaway reaction initiation temperature are presented in Table 4. 
WSRC-TR-2000-00427

Revision 0

Table 3 Nitric Acid Concentration in TBP Samples Used for RSST ${ }^{\mathrm{TM}}$ Experiments

\begin{tabular}{|c|c|c|c|c|}
\hline \multirow[t]{2}{*}{ Run No. } & \multicolumn{2}{|c|}{ Aqueous Phase } & \multirow{2}{*}{$\begin{array}{c}\text { Organic Phase } \\
\text { Nitric Acid } \\
\text { (moles } / \mathrm{L} \text { ) }\end{array}$} & \multirow{2}{*}{$\begin{array}{c}\text { Initiation } \\
\text { Temperatur } \\
\left({ }^{\circ} \mathrm{C}\right)\end{array}$} \\
\hline & $\begin{array}{l}\text { Nitric Acid } \\
\text { (moles/L) }\end{array}$ & $\begin{array}{c}\mathrm{Al}\left(\mathrm{NO}_{3}\right)_{3} \\
(\mathrm{wt} \%)\end{array}$ & & \\
\hline TBP $0 / 8-3$ & 8.00 & 0 & 3.0810 & 153 \\
\hline ТВР $0 / 10-1$ & 10.00 & 0 & 3.5124 & 144 \\
\hline ТВP 0/12-1 & 12.00 & 0 & 4.1521 & 139 \\
\hline ТВР 0/13-1 & 13.00 & 0 & 4.5262 & 142 \\
\hline TBP $0 / 14-1$ & 14.00 & 0 & 4.8299 & 139.5 \\
\hline TBP 5/4-8 & 4.00 & 5.00 & 2.3736 & 154.5 \\
\hline TBP 5/6-2 & 6.00 & 5.00 & 2.8337 & 150.5 \\
\hline TBP $5 / 8-2^{(1)}$ & 8.00 & 5.02 & 3.2057 & 148 \\
\hline TBP $10 / 4-1$ & 4.00 & 10.01 & 2.4751 & 152.5 \\
\hline TBP $10 / 4-2^{(2)}$ & 4.00 & 10.00 & 2.0588 & 155.5 \\
\hline TBP $10 / 6-1$ & 6.00 & 10.01 & 2.9746 & 149.5 \\
\hline TBP $10 / 8-1$ & 8.00 & 10.01 & 3.4309 & 147 \\
\hline TBP $10 / 8-2^{(1)}$ & 8.00 & 10.01 & 3.2708 & 147 \\
\hline TBP $10 / 9-1$ & 8.99 & 10.01 & 3.6747 & 148 \\
\hline TBP 10/10-1 & 10.00 & 10.00 & 3.8916 & 146 \\
\hline TBP $10 / 10-2$ & 10.00 & 10.00 & 3.8933 & 146 \\
\hline TBP $20 / 4-2$ & 4.00 & 19.99 & 2.8078 & 156 \\
\hline TBP $20 / 6-2$ & 6.00 & 20.00 & 3.0770 & 152.5 \\
\hline TBP 20/6-3 & 6.00 & 19.99 & 3.2256 & 147.5 \\
\hline ТВP $20 / 7-1$ & 7.00 & 20.00 & 3.4274 & 139.5 \\
\hline TВP 20/7-3 & 7.00 & 20.00 & 3.6193 & 150 \\
\hline TBP 20/7-4 & 7.00 & 20.00 & 3.4772 & 148 \\
\hline
\end{tabular}

(1) $\mathrm{NaNO}_{3}$ used as Dissolved Solid

(2) $\mathrm{KNO}_{3}$ used as Dissolved Solid

The Davis data and the measured values for TBP contacted with an aqueous phase containing $20 \mathrm{wt} \% \mathrm{Al}\left(\mathrm{NO}_{3}\right)_{3}$ can also be used to estimate the concentration of nitric acid in the TBP samples used by Colven [2] to measure the initiation temperature for a runaway TBP/nitric acid reaction. Estimates for most of the Colven data and the corresponding runaway reaction initiation temperatures are presented in Table 5. 
Table 4 Estimated Nitric Acid Concentration in TBP Samples Used for RSST ${ }^{\mathrm{TM}}$ Experiments

\begin{tabular}{|c|c|c|c|c|}
\hline \multirow[t]{2}{*}{ Run No. } & \multicolumn{2}{|c|}{ Aqueous Phase } & \multirow{2}{*}{$\begin{array}{c}\text { Organic Phase } \\
\text { Nitric Acid } \\
\text { (moles } / \text { L) }\end{array}$} & \multirow{2}{*}{$\begin{array}{c}\text { Initiation } \\
\text { Temperature } \\
\left({ }^{\circ} \mathrm{C}\right)\end{array}$} \\
\hline & $\begin{array}{c}\text { Nitric Acid } \\
(\text { moles } / L)\end{array}$ & $\begin{array}{c}\mathrm{Al}\left(\mathrm{NO}_{3}\right)_{3} \\
\quad(\mathrm{wt} \%) \\
\end{array}$ & & \\
\hline TBP 0/4-3 & 4.00 & 0 & 2.330 & 157 . \\
\hline TВP $0 / 8-2$ & 8.00 & 0 & 3.370 & 150.5 \\
\hline TBP 0/15-2 & 14.99 & 0 & 5.784 & 139 \\
\hline TBP $0 / 15-3$ & 15.00 & 0 & 5.790 & 137 \\
\hline TBP 5/4-7 & 4.00 & 5.00 & 2.330 & 157 \\
\hline TBP 5/8-1 & 8.00 & 5.00 & 3.370 & 146 \\
\hline TBP $5 / 10-1$ & 10.00 & 5.00 & 3.820 & 143 \\
\hline TBP 5/12-3 & 11.99 & 5.00 & 4.37 & 139 \\
\hline TBP 5/12-4 & 12.00 & 5.01 & 4.37 & 139.5 \\
\hline TBP 20/4-1 & 4.00 & 20.00 & 2.76 & 148.5 \\
\hline TBP 20/6-1 & 6.00 & 20.00 & 3.14 & 149 \\
\hline TBP 20/8-1 & 8.00 & 20.00 & 3.70 & 147.5 \\
\hline
\end{tabular}

Table 5 Estimated Organic Phase Nitric Acid Concentrations for Colven Data

\begin{tabular}{cccc}
\hline \hline $\begin{array}{c}\text { Aqueous Phase } \\
\begin{array}{c}\text { Nitric Acid } \\
(\text { moles/L) }\end{array}\end{array}$ & $\begin{array}{c}\text { Est Organic Phase } \\
\text { Nitric Acid } \\
(\text { moles } / \text { ) })\end{array}$ & $\begin{array}{c}\text { Initiation } \\
\text { Temperature } \\
\left({ }^{\circ} \mathrm{C}\right)\end{array}$ \\
\hline 3.9 & 0 & 2.294 & 161 \\
4.2 & 0 & 2.398 & 158 \\
5.1 & 0 & 2.678 & 156 \\
6.0 & 0 & 2.920 & 155 \\
6.9 & 0 & 3.128 & 151 \\
8.1 & 0 & 3.392 & 149 \\
8.3 & 0 & 3.436 & 151.5 \\
8.6 & 0 & 3.502 & 150 \\
8.8 & 0 & 3.546 & 148 \\
10.0 & 0 & 3.700 & 142 \\
10.0 & 0 & 3.700 & 144 \\
10.0 & 0 & 3.700 & 148 \\
15.7 & 0 & $\mathrm{~N} / \mathrm{A}^{(1)}$ & 132 \\
15.7 & 0 & $\mathrm{~N} / \mathrm{A}^{(1)}$ & 136 \\
15.7 & 0 & $\mathrm{~N} / \mathrm{A}^{(1)}$ & 137 \\
5.7 & 20 & 3.09 & 153 \\
8.1 & 20 & $3.75^{(2)}$ & 131.5 \\
9.6 & 20 & $\mathrm{~N} / \mathrm{A}^{(1)}$ & 129 \\
\hline
\end{tabular}

(1) Outside Bounds of Available Data

(2) Extrapolated Value Using Data at 8M Nitric Acid 
The data from Tables 3, 4, and 5 were plotted on Figure 9 to show the initiation temperature for a runaway TBP/nitric acid reaction as a function of the nitric acid concentration in the organic phase. From Figure 9, one can generally see a linear decrease in the initiation temperature as the extracted nitric acid concentration increases. This behavior is not unexpected. The initiation temperature should decrease as the amount of oxidant (nitric acid) increases. The higher nitric acid concentration permits a faster reaction (oxidation) rate at a lower temperature which reduces the temperature where runaway reaction occurs.

The data plotted on Figure 9 also illustrates that the runaway reaction initiation temperatures measured by Colven [2] using TBP contacted with an aqueous phase containing $8-10 \mathrm{M}$ nitric acid and $20 \mathrm{wt} \% \mathrm{Na} / \mathrm{KNO}_{3}$ are excessively low. An extrapolation of the data plotted on Figure 8 was used to estimate the extracted nitric acid concentration for one of the two Colven data points ( $8.1 \mathrm{M}$ nitric acid and $20 \mathrm{wt} \% \mathrm{Na} / \mathrm{KNO}_{3}$ ). The measured initiation temperature for this experiment is approximately $15^{\circ} \mathrm{C}$ below the expected value based on the linear regression line used to correlate the data. One would also expect the initiation temperature for the Colven experiment performed using an aqueous phase nitric acid concentration of $9.6 \mathrm{M}$ to be approximately $10^{\circ} \mathrm{C}$ higher based on the experimental data.

\section{Effect of Other Variables on Initiation Temperature}

Several RSST ${ }^{\mathrm{TM}}$ experiments were performed to look at the effect of other variables (nitrate salt and number of phases) on the initiation temperature for a runaway TBP/nitric acid reaction. A baseline experiment was also performed in which an RSST $^{\mathrm{TM}}$ run was made using pure TBP to ensure no exothermic behavior (from thermal decomposition products) was seen up to a temperature of $200^{\circ} \mathrm{C}$. In this experiment (TBP 0/0-1), the TBP temperature increased at nominally $1^{\circ} \mathrm{C} / \mathrm{min}$ until the termination of the experiment and no self-heating was seen. The temperature and pressure profiles for the experiment are included in Appendix D (see Figure D.1).

Since the dissolved solids used by Colven [2] to measure the initiation temperature for a runaway TBP/nitric acid reaction were either $\mathrm{NaNO}_{3}$ or $\mathrm{KNO}_{3}, \mathrm{RSST}{ }^{\mathrm{TM}}$ experiments were performed for comparison using TBP contacted with nitric acid solutions containing both of these salts. Two RSST $^{\text {TM }}$ runs (TBP 5/8-2 and TBP 10/8-2) were performed using $\mathrm{NaNO}_{3}$ and one (TBP 10/4-2) with $\mathrm{KNO}_{3}$ as the dissolved solid. The runaway reaction initiation temperatures measured for these experiments were almost identical to the temperatures measured in experiments using the same nitric acid concentration and $\mathrm{Al}\left(\mathrm{NO}_{3}\right)_{3}$ as the dissolved solid (see Table 2). Apparently the salting effect of $\mathrm{Al}\left(\mathrm{NO}_{3}\right)_{3}$ is not significantly greater than the effect for $\mathrm{NaNO}_{3}$ and $\mathrm{KNO}_{3}$ at these concentrations of dissolved solids.

RSST $^{\mathrm{TM}}$ experiments were also performed to evaluate the effect of additional phases (aqueous and solid) on the thermal behavior of the TBP samples. One experiment (TBP 0/8-3) was performed in which a $1 \mathrm{~mL}$ aliquot of the aqueous phase originally used to contact the TBP was also added to the RSSTrm test cell. The presence of the aqueous phase had little effect on the runaway reaction initiation temperature. The measured value was approximately the same (153 
versus $150.5^{\circ} \mathrm{C}$ ) as the temperature measured during an RSST'M run (TBP 0/8-2) performed with just the organic phase contacted with an aqueous solution containing the same nitric acid and $\mathrm{Al}\left(\mathrm{NO}_{3}\right)_{3}$ concentrations. The only noticeable difference in thermal behavior was the extended time required to evaporate the aqueous phase prior to runaway reaction occurring. The temperature profiles which illustrate this point are contained in Appendix D (see Figures D.3 and D.4).

A second experiment was performed in which organic and aqueous phases and a small amount of solid $\mathrm{Al}\left(\mathrm{NO}_{3}\right)_{3}$ were added to the RSST ${ }^{\mathrm{TM}}$ test cell. In this experiment (TBP 5/12-4), a single seed crystal was added to the separated aqueous phase following contact with TBP. The seeded solution was placed in an ice bath to promote crystallization. Within a few minutes crystals had formed. The two phase mixture was removed from the ice bath and allowed to return to room temperature. A $1 \mathrm{~mL}$ aliquot of the mixture, including solid $\mathrm{Al}\left(\mathrm{NO}_{3}\right)_{3}$ crystals, was added to the RSST test cell with the organic phase. The presence of the aqueous and solid $\mathrm{Al}\left(\mathrm{NO}_{3}\right)_{3}$ phases had almost no effect on the runaway reaction initiation temperature. The initiation temperature was $139.5^{\circ} \mathrm{C}$ compared to a value of $139^{\circ} \mathrm{C}$ measured during an $\mathrm{RSST}^{\mathrm{TM}}$ run (TBP 5/12-3) using just the organic phase which had been contacted with an aqueous solution containing the same concentrations of nitric acid and $\mathrm{Al}\left(\mathrm{NO}_{3}\right)_{3}$. Like the two phase experiment, the only noticeable difference in the thermal behavior of the two experiments was the extended time required to evaporate the aqueous phase prior to the runaway reaction. The temperature profiles for the two experiments are presented in Appendix D (see Figures D.17 and D.18).

\section{Nitrate Salt Solubility Limitations}

The preparation of TBP samples for a number of RSST ${ }^{\mathrm{TM}}$ experiments was aborted due to the precipitation of the dissolved solids while contacting the aqueous and organic phases. The precipitation was attributed to the concentration of the salt by extraction of nitric acid and water into the TBP. Solubility data for $\mathrm{Al}\left(\mathrm{NO}_{3}\right)_{3}$ [13] (see Figure 10) show that nitric acid concentrations slightly greater than 8,6 , and $3 \mathrm{M}$ should result in the precipitation of $\mathrm{Al}\left(\mathrm{NO}_{3}\right)_{3}$ crystals from solutions containing 5, 10, and $20 \mathrm{wt} \%$ dissolved solids, respectively. Therefore, RSST $^{\mathrm{T} M}$ experiments performed with more concentrated nitric acid solutions using these concentrations of $\mathrm{Al}\left(\mathrm{NO}_{3}\right)_{3}$ were actually supersaturated and would not be stable over a long period of time. Successful RSST ${ }^{\mathrm{TM}}$ experiments were performed with TBP contacted with aqueous phases containing 5,10, and $20 \mathrm{wt} \% \mathrm{Al}\left(\mathrm{NO}_{3}\right)_{3}$ in 12,10 , and $8 \mathrm{M}$ nitric acid, respectively. A number of unsuccessful attempts (see Appendix B, Table B.2) were made to perform RSST ${ }^{\mathrm{TM}}$ experiments using more concentrated nitric acid at $20 \mathrm{wt} \%$ dissolved solids by taking advantage of the increased solubility of $\mathrm{KNO}_{3}$ compared to either $\mathrm{Al}\left(\mathrm{NO}_{3}\right)_{3}$ or $\mathrm{NaNO}_{3}$ at high acid concentrations (see Figure 10). However, concentration of the $\mathrm{KNO}_{3}$ during the extraction resulted in the formation of a precipitate during each experiment at this level of dissolved solids: This prevented the duplication of the experiments performed by Colven [2] using $20 \mathrm{wt} \%$ dissolved solids and nitric acid concentrations greater than $8 \mathrm{M}$. 


\section{This page was intentionally left blank.}




\section{Conclusions}

An RSST ${ }^{\mathrm{TM}}$ was used to investigate the thermal stability of TBP contacted with an aqueous phase containing $2-15 \mathrm{M}$ nitric acid and 0 to $20 \mathrm{wt} \%$ dissolved solids. The initial experiments were performed with the RSST ${ }^{\mathrm{TM}}$ open to atmospheric pressure. In these experiments, the runaway reaction initiation temperature was defined as the temperature of the TBP when the self-heating rated diverged from the imposed heat-up rate of $1^{\circ} \mathrm{C} / \mathrm{min}$. However, the initiation temperatures measured in this manner were not consistent with the expected results showing a general increase with increasing aqueous phase nitric acid concentration. Based on this observation, RSST ${ }^{\mathrm{TM}}$ experiments were performed in which the TBP temperature was increased in a step-wise manner to determine if a runaway reaction occurred. The results from these experiments showed that the self-heating rate was not sufficient for runaway reaction to occur. This observation is consistent with the results from previous studies which showed that adequate venting of vessels is the first defense against a damaging runaway reaction.

To obtain a runaway TBP/nitric acid reaction, it was necessary to seal the RSST ${ }^{\mathrm{TM}}$ safety vessel at atmospheric pressure prior to the initiation of an experiment. Without adequate venting, selfheating from the oxidation of TBP degradation products was sufficient for runaway reaction to occur. At the point of runaway, both rapid increases in the RSST ${ }^{\mathrm{TM}}$ safety vessel pressure and TBP temperature were seen. The runaway reaction initiation temperature was defined by the time and corresponding temperature when a rapid increase in the pressure was initially seen. This procedure worked well except for experiments performed with TBP contacted with aqueous solutions containing high concentrations (13-15M) of nitric acid. In these experiments, the evaporation of water and nitric acid caused a gradual increase in pressure well before runaway reaction occurred. To define the runaway reaction initiation temperature, it was necessary to compare both temperature and pressure profiles to ensure that rapid increases in both temperature and pressure were occurring at the same time.

The runaway reaction initiation temperatures for TBP contacted with nitric acid solutions containing no dissolved solids were in good agreement with Colven's data.[2] The initiation temperature gradually decreased with increasing aqueous phase nitric acid concentration. The decrease in the initiation temperature was due to the increase in the available oxidant (nitric acid) extracted by the TBP. The minimum initiation temperature, $137^{\circ} \mathrm{C}$, measured at $14-15 \mathrm{M}$ nitric acid was consistent with the values $\left(132-137^{\circ} \mathrm{C}\right)$ measured by Colven at nominally $15.7 \mathrm{M}$ nitric acid. The initiation temperatures measured using TBP contacted with nitric acid solutions containing 5, 10, and $20 \mathrm{wt} \%$ dissolved solids showed a small dependence on the salt concentration; however, the lowest temperatures were several degrees above the minimum value for no dissolved solids. The slight lowering of the initiation temperature was attributed to the increased extraction of nitric acid due to the salting-out effect of the dissolved solids.

From the results of the closed RSST ${ }^{\mathrm{TM}}$ experiments, it was clear that the initiation temperature for a runaway $\mathrm{TBP} /$ nitric acid reaction decreased with increasing nitric acid concentration in the TBP. To illustrate this point the initiation temperature was correlated with the amount of nitric acid extracted into the organic phase. The extracted nitric acid concentration waseither analyzed 
or estimated using published values or the results of separate experiments. An estimate of the nitric acid concentration in most of the TBP samples used by Colven [2] was obtained by the same procedure. When the runaway reaction initiation temperature was plotted as a function of the extracted nitric acid concentration, the temperature decreased linearly with increasing concentration. A higher nitric acid concentration in the TBP results in a faster reaction (oxidation) rate at a lower temperature which reduces the temperature where runaway reaction occurs. The correlation also illustrated that initiation temperatures measured by Colven using TBP contacted with an aqueous phase containing $8-10 \mathrm{M}$ nitric acid and $20 \mathrm{wt} \% \mathrm{Na} / \mathrm{KNO}_{3}$ are excessively low. The measured initiation temperatures were $10-15^{\circ} \mathrm{C}$ below the expected values based on the linear regression line used to correlated the data.

A number of RSST ${ }^{\mathrm{TM}}$ experiments were performed to look at the effect of other variables (nitrate salt and number of phases) on the initiation temperature for a runaway TBP/nitric acid reaction. Experiments were performed in which the dissolved solids were changed from $\mathrm{Al}\left(\mathrm{NO}_{3}\right)_{3}$ to $\mathrm{NaNO}_{3}$, or $\mathrm{KNO}_{3}$. No significant effect on the initiation temperature was seen. RSST ${ }^{\mathrm{TM}}$ experiments were also performed to evaluate the effect of additional phases (aqueous and solid) on the thermal behavior of the TBP samples. Neither the presence of the aqueous phase originally used to contact the TBP nor a small amount of undissolved solids in the aqueous phase had a significant effect on the runaway reaction initiation temperature. The only noticeable difference in thermal behavior was the extended time required to evaporate the aqueous phase prior to runaway reaction occurring.

The preparation of TBP samples for a number of RSST ${ }^{\mathrm{TM}}$ experiments was aborted due to the precipitation of the dissolved solids while contacting the aqueous and organic phases. The precipitation was attributed to the concentration of the salt by extraction of nitric acid and water into the TBP. Solubility data for $\mathrm{Al}\left(\mathrm{NO}_{3}\right)_{3}$ showed that nitric acid concentrations slightly greater than 8,6 , and $3 \mathrm{M}$ should result in precipitation of $\mathrm{Al}\left(\mathrm{NO}_{3}\right)_{3}$ from solutions containing 5,10 , and $20 \mathrm{wt} \%$ dissolved solids, respectively. Therefore, RSST $^{\mathrm{TM}}$ experiments performed with more concentrated nitric acid solutions using these concentrations of $\mathrm{Al}\left(\mathrm{NO}_{3}\right)_{3}$ were actually supersaturated and would not be stable over a long period of time. 
References

1. J. E. Laurinat, N. M. Hassan, T. S. Rudisill, and N. M. Askew, Analysis of Steam heating of TBP/n-Paraffin/Nitric Acid Mixtures, WSRC-TR-98-00171, Revision 1, Westinghouse Savannah River Company, Aiken, SC, July 22, 1998.

2. T. J. Colven, Jr., Nitric Acid Recovery Units Permissible Steam Pressure in Reboilers, DPST-56-243, E. I. Du Pont de Nemours \& Company, Aiken, SC, April 27, 1956.

3. J. R. Smith and W. S. Cavin, Isothermal Heat Measurements of TBP-Nitric Acid Solutions, WSRC-TR-94-0540, Westinghouse Savannah River Company, Aiken, SC, December 16, 1994.

4. M. L. Hyder, W. C. Perkins, M. C. Thompson, G. A. Burney, E. R. Russell, H. P. Holcomb, and L. F. Landon, Processing of Irradiated Enriched Uranium Fuels at the Savannah River Plant, DP-1500, E. I. Du Pont de Nemours \& Company, Aiken, SC, April 1979.

5. G. H. Morrison and H. Freiser, Solvent Extraction in Analytical Chemistry, John Wiley \& Sons, Inc., New York, NY, 1957, pp. 43-45.

6. M. C. Thompson, Distribution of Selected Lanthanides and Actinides Between $30 \%$ TBP in $n$-Paraffin and Various Metal Nitrate Solutions, E. I. du Pont de Nemours \& Co., Aiken, SC, November 1973.

7. F. A. Cotton and G. Wilkinson, Advanced Inorganic Chemistry, $5^{\text {th }}$ Edition, John Wiley \& Sons, Inc., New York, NY, 1988, pp. 132 and 215,

8. M. J. Creed and H. K. Fauske, Chem. Eng. Prog., March, 1990, p. 45.

9. W. Davis, Jr., J. Mrochek, and C. J. Hardy, J. Inorg. Nucl. Chem., Vol. 28, 1966, pp. 20012014.

10. M. L. Hyder, Safe Handling of TBP and Nitrates in the Nuclear Process Industry, WSRC-TR-94-0372, Westinghouse Savannah River Company, Aiken, SC, July 1994.

11. Fauske \& Associates, Inc., Tributyl Phosphate-Nitric Acid Reaction and Vent Requirement, FAI/94-68, Burr Ridge, IL, July 1994.

12. T. J. Colven, Jr., G. M. Nichols, and T. H. Siddall, Interim Technical Report, TNX Evaporator Incident, January 12, 1953, DP-25, E. I. du Pont de Nemours \& Co., Aiken, SC, May 15, 1953. 
13. W. F. Linke, Editor, Solubilities Inorganic and Metal-Organic Compounds, Vol. I, $4^{\text {th }}$ Edition, D. Van Nostrand Company, Inc. Princeton, NJ, 1958, pp. 188-189.

14. W. F. Linke, Editor, Solubilities Inorganic and Metal-Organic Compounds, Vol. II, $4^{\text {th }}$ Edition, D. Van Nostrand Company, Inc. Princeton, NJ, 1965, p. 1071.

15. Ibid. pp. 251-253. 
Figure 1 Colven Data - Initiation Temperature for Runaway TBP/Nitric Acid Reaction [2]

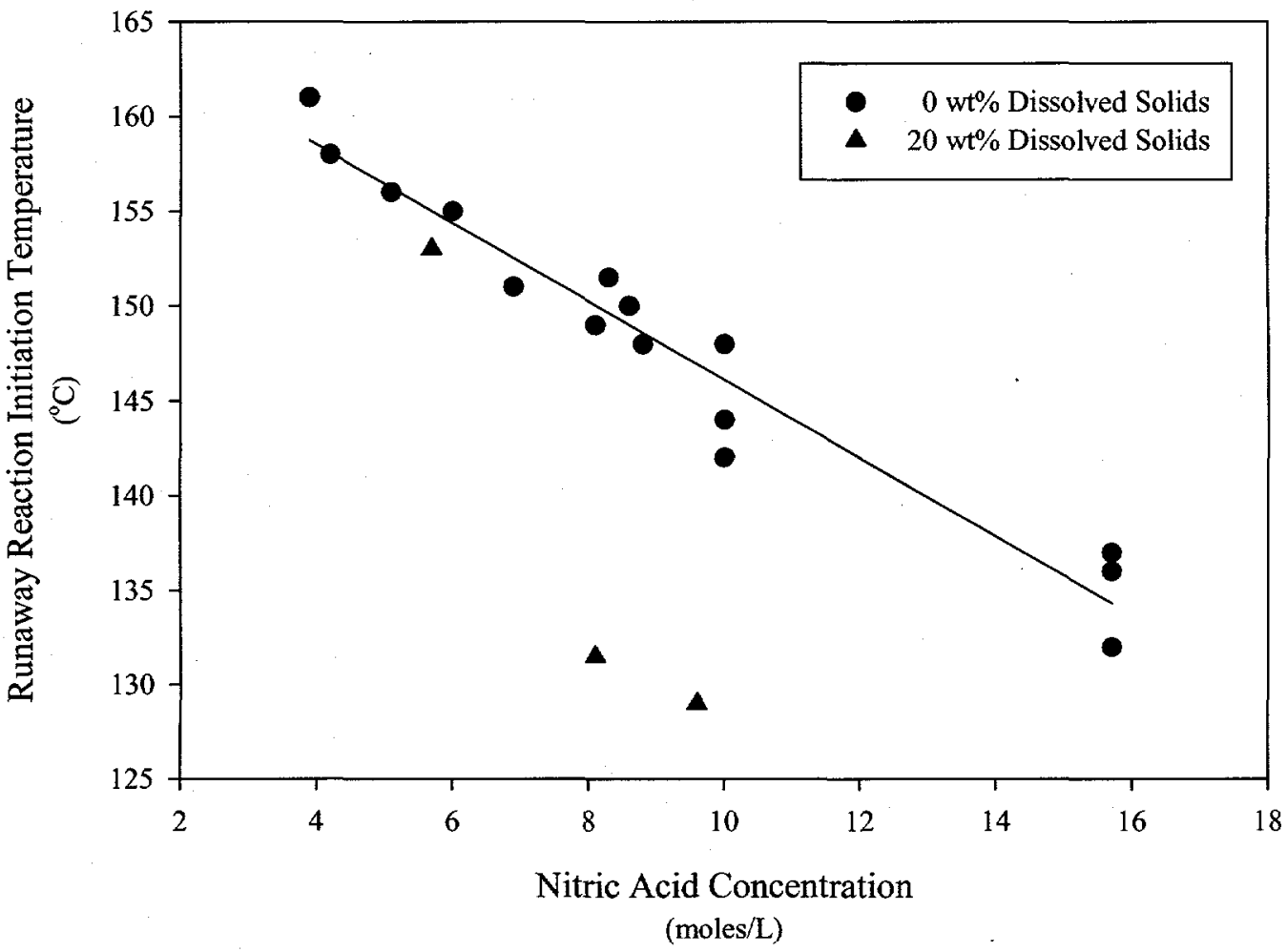


This page was intentionally left blank. 
Figure 2 RSST Pressure Vessel

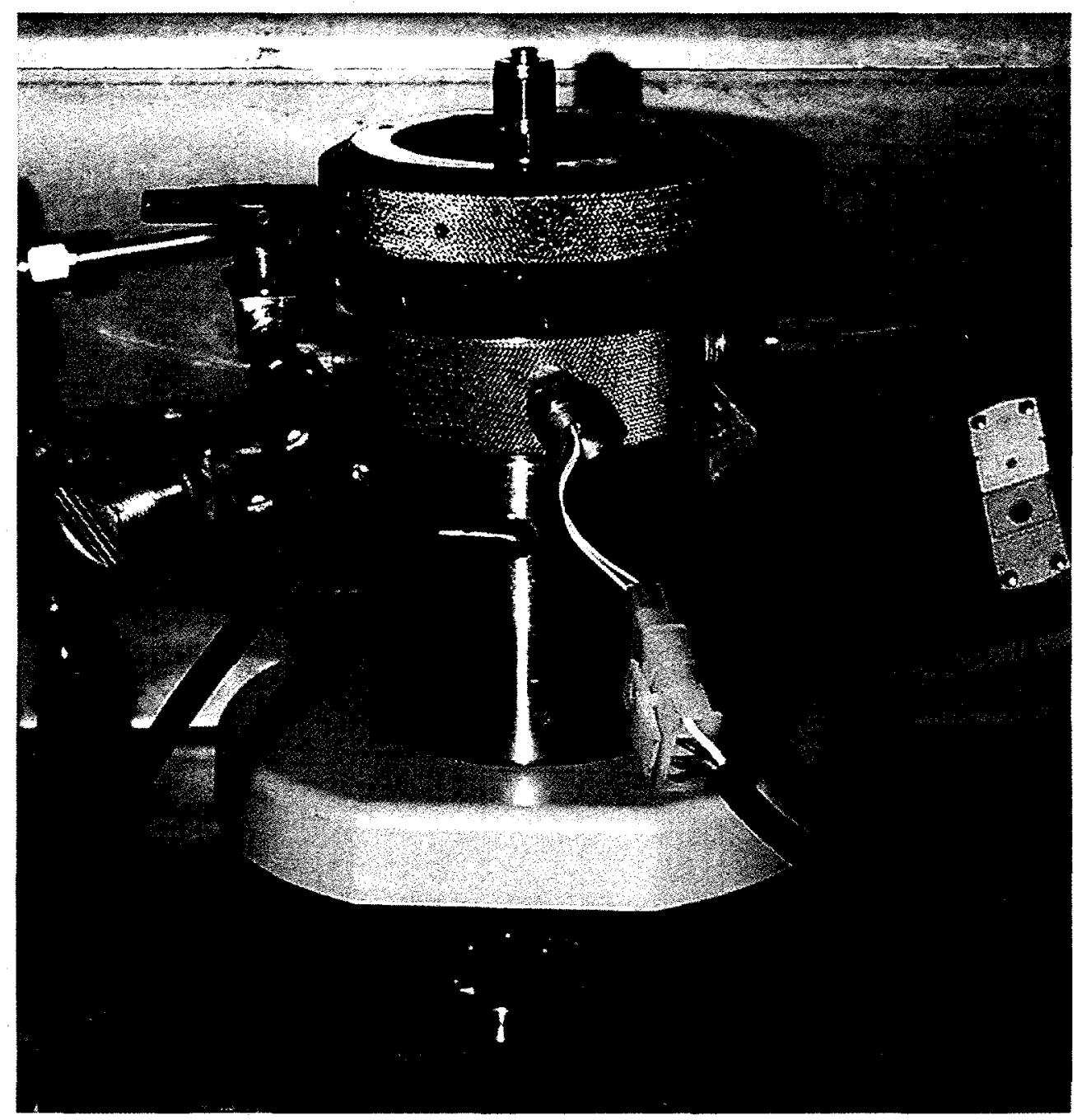


This page was intentionally left blank. 
Figure 3 Temperature Profile and Self-Heating Rate for Open System Run No. TBP 5/12-5
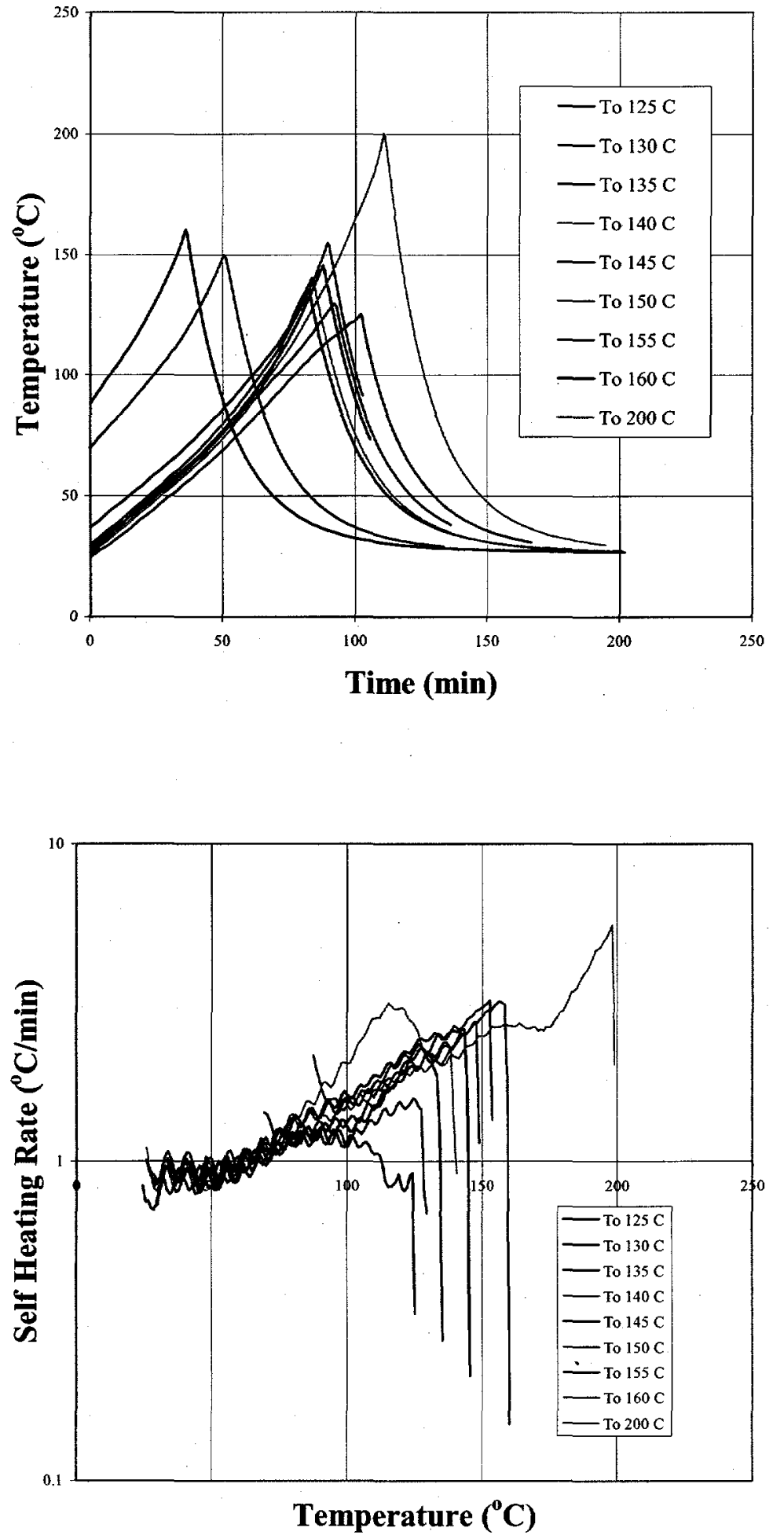

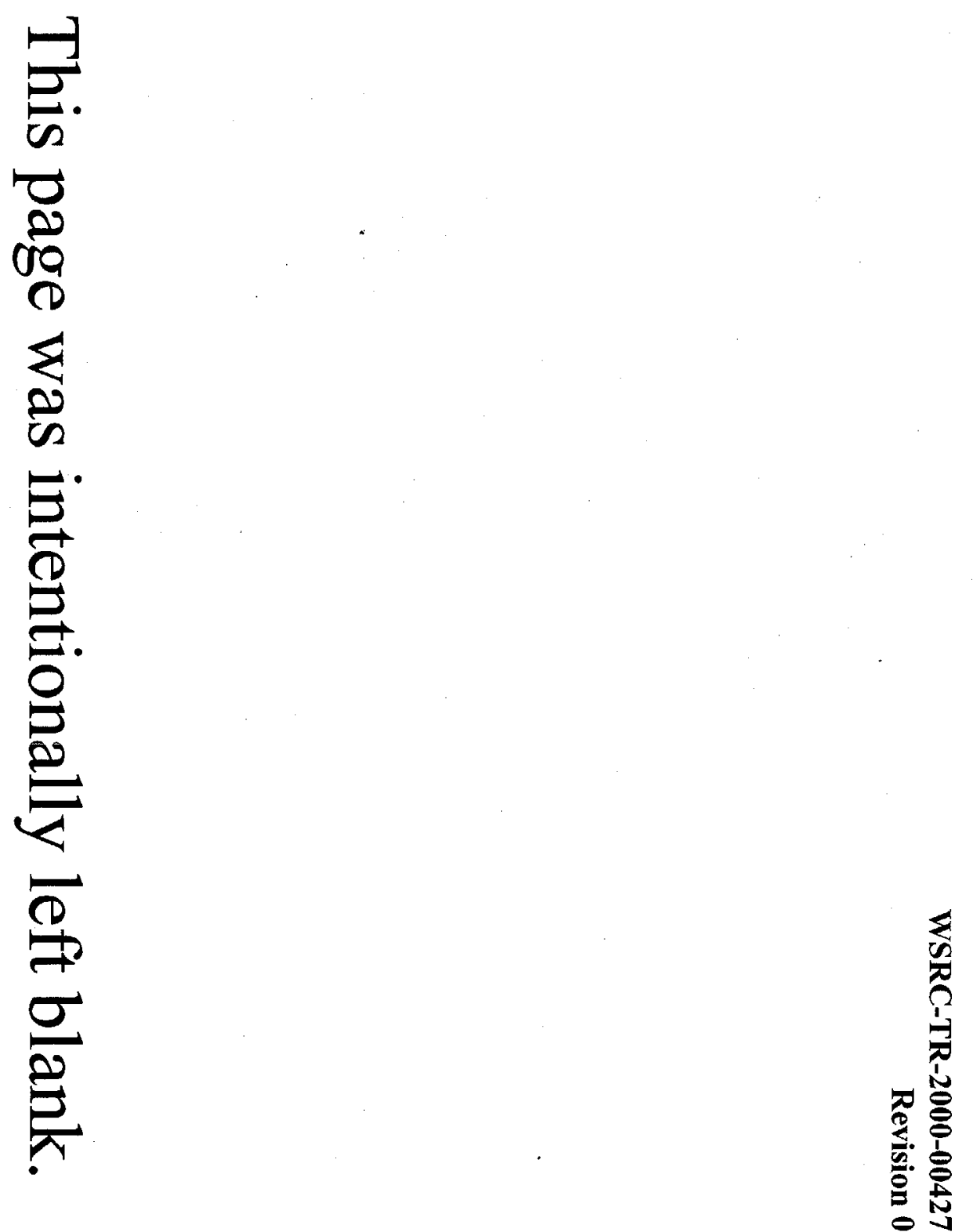
Figure 4 Temperature Profile and Self-Heating Rate for Open System Run No. TBP 5/12-6
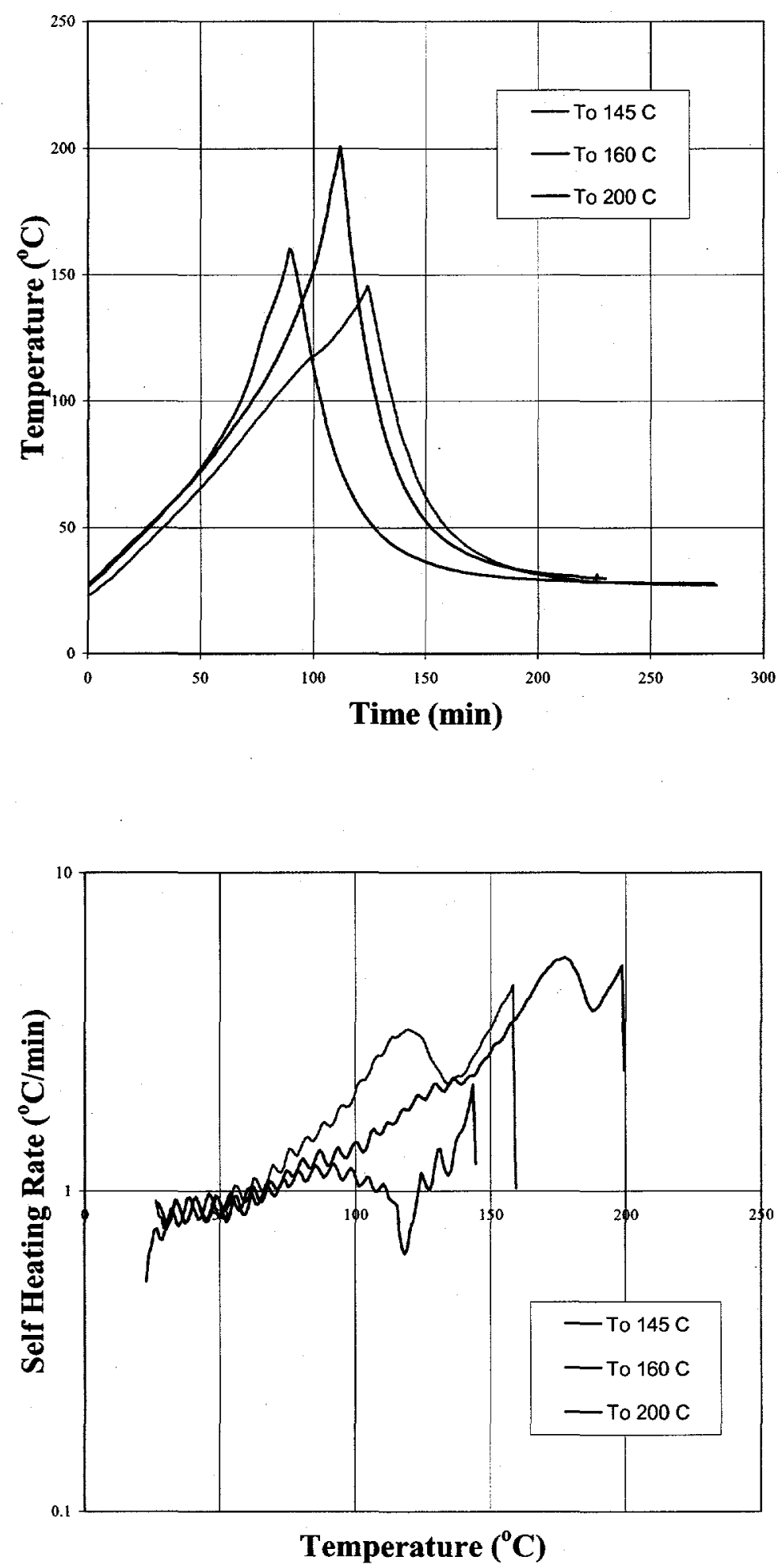
This page was intentionally left blank. 
Figure 5 Defining the Initiation Temperature for a Runaway TBP/Nitric Acid Reaction (Run No. TBP 0/8-3)
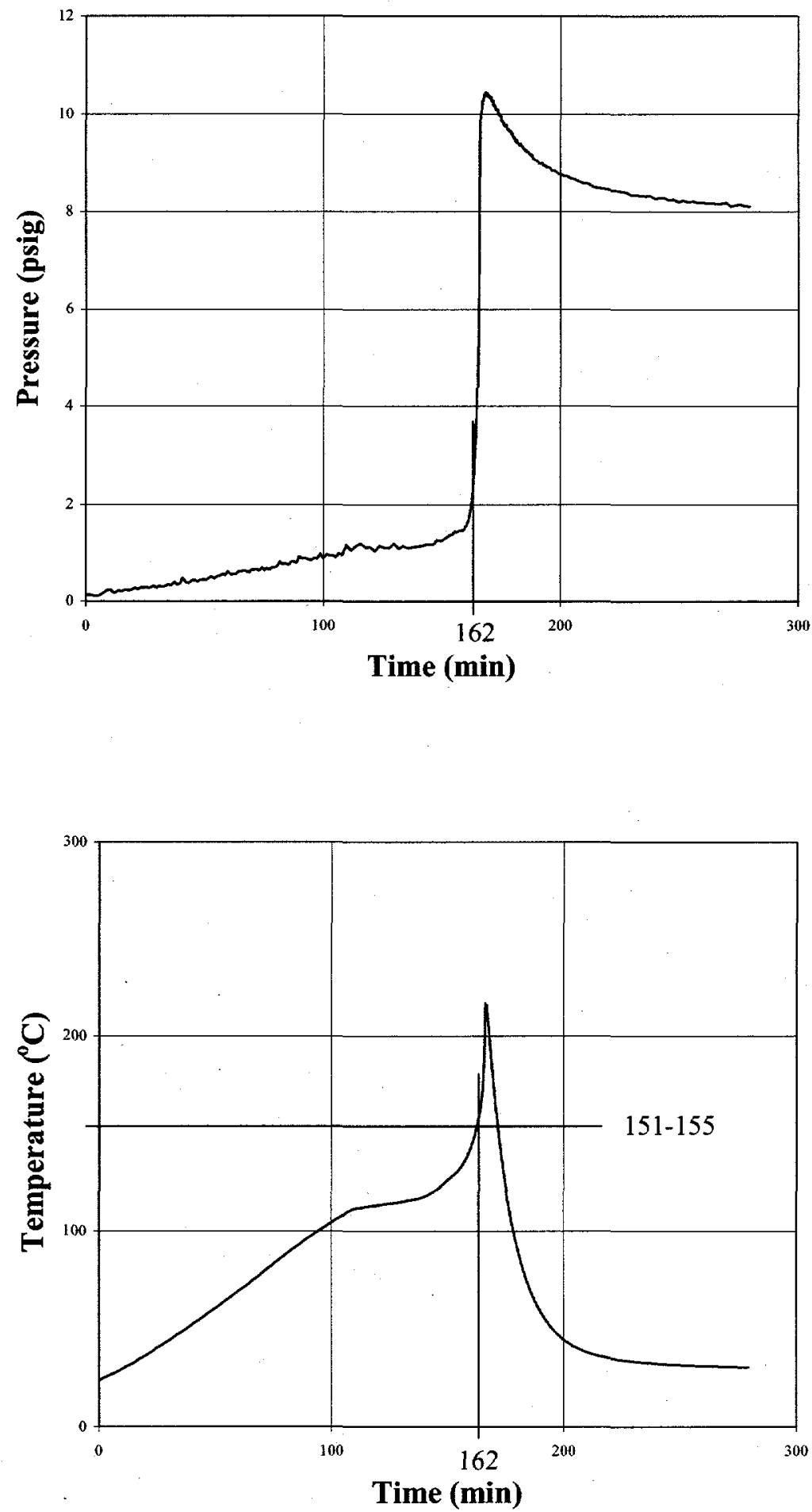


\section{This page was intentionally left blank.}


Figure 6 Effect of Acid Concentration and Solids Content on the Initiation Temperature for a Runaway TBP/Nitric Acid

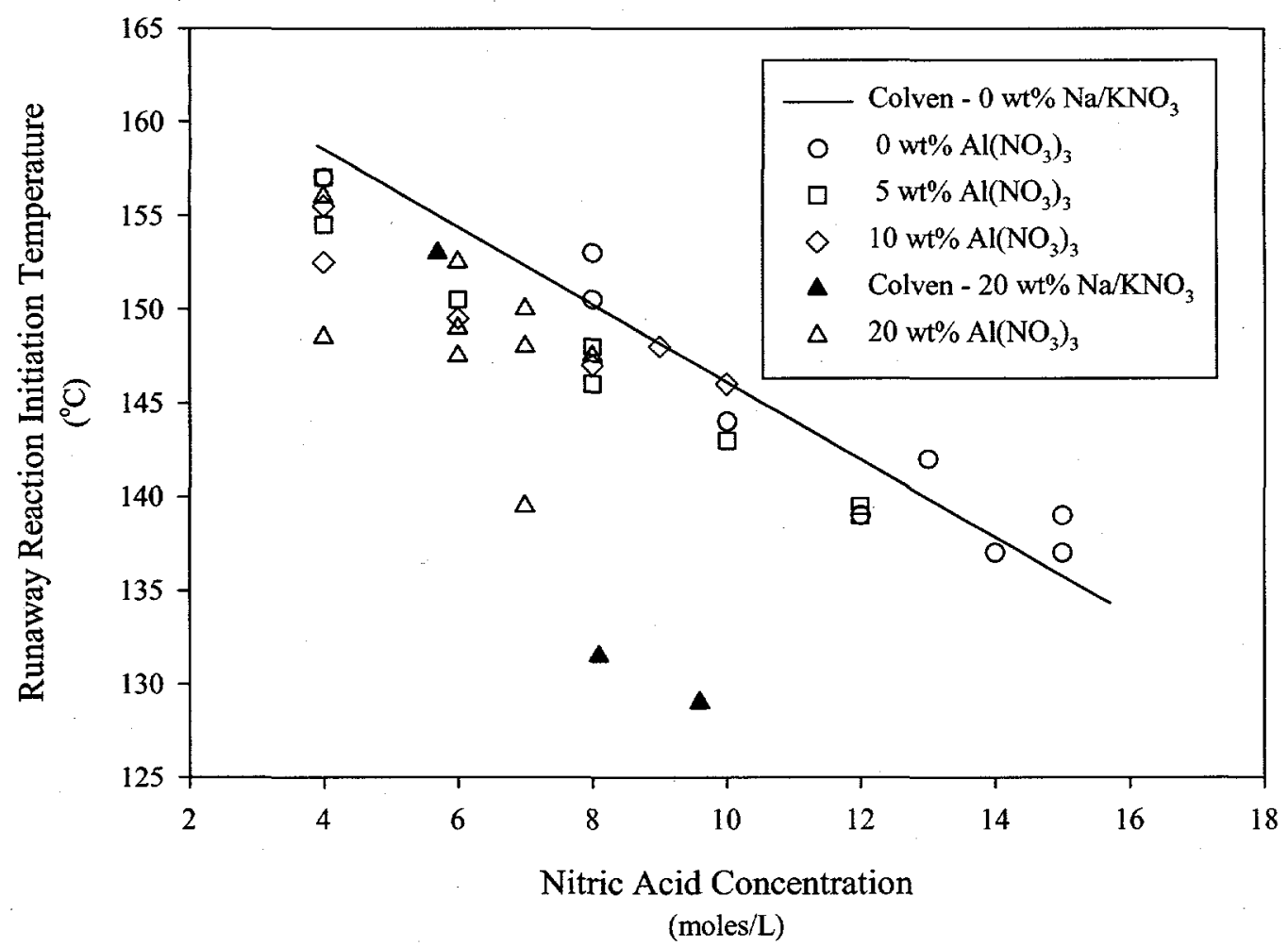


This page was intentionally left blank. 
Figure 7 Regression Analysis for Runaway TBP/Nitric Acid Initiation Temperature

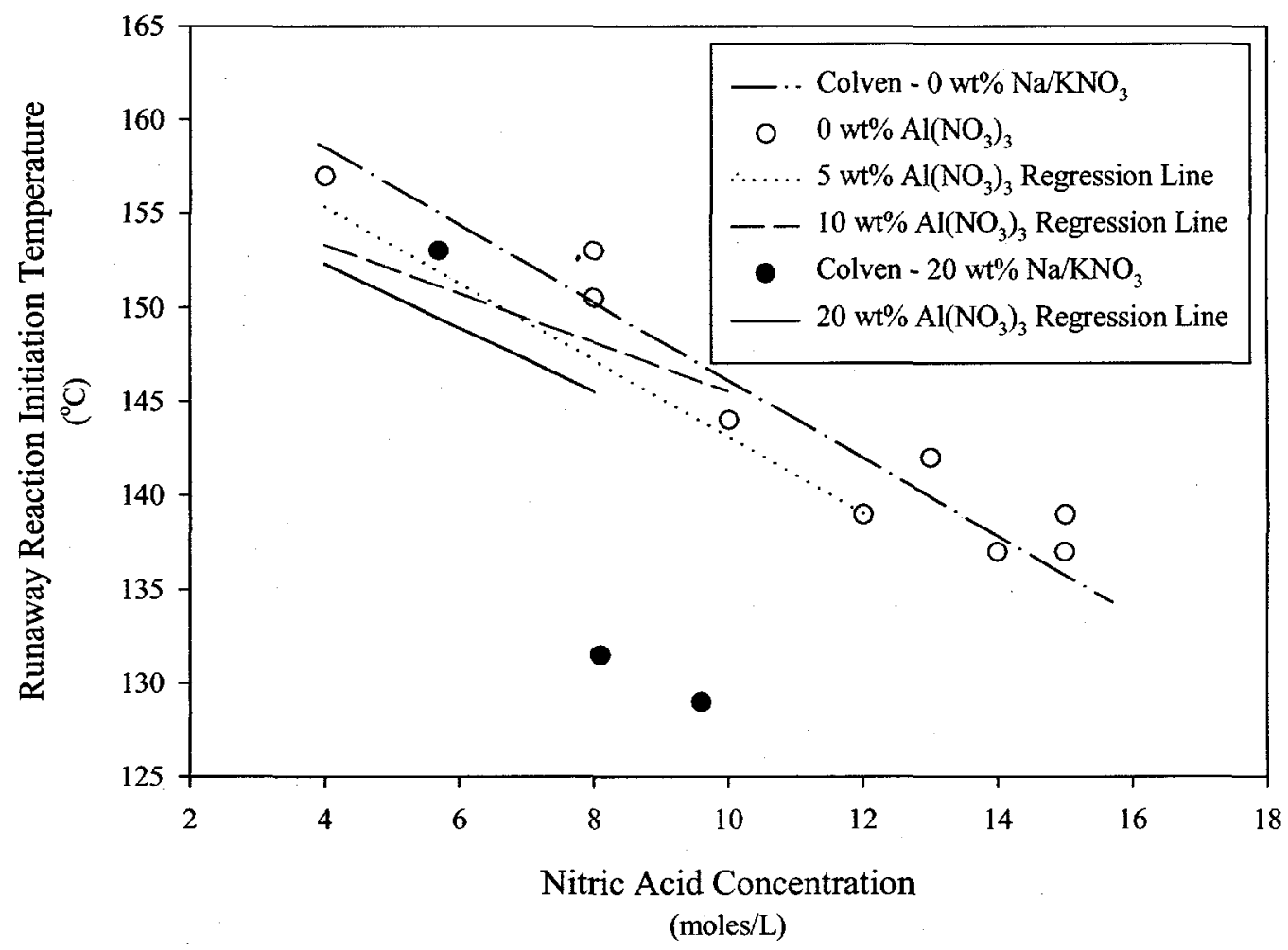




\section{This page was intentionally left blank.}


Figure 8 Extraction of Nitric Acid into Pure TBP

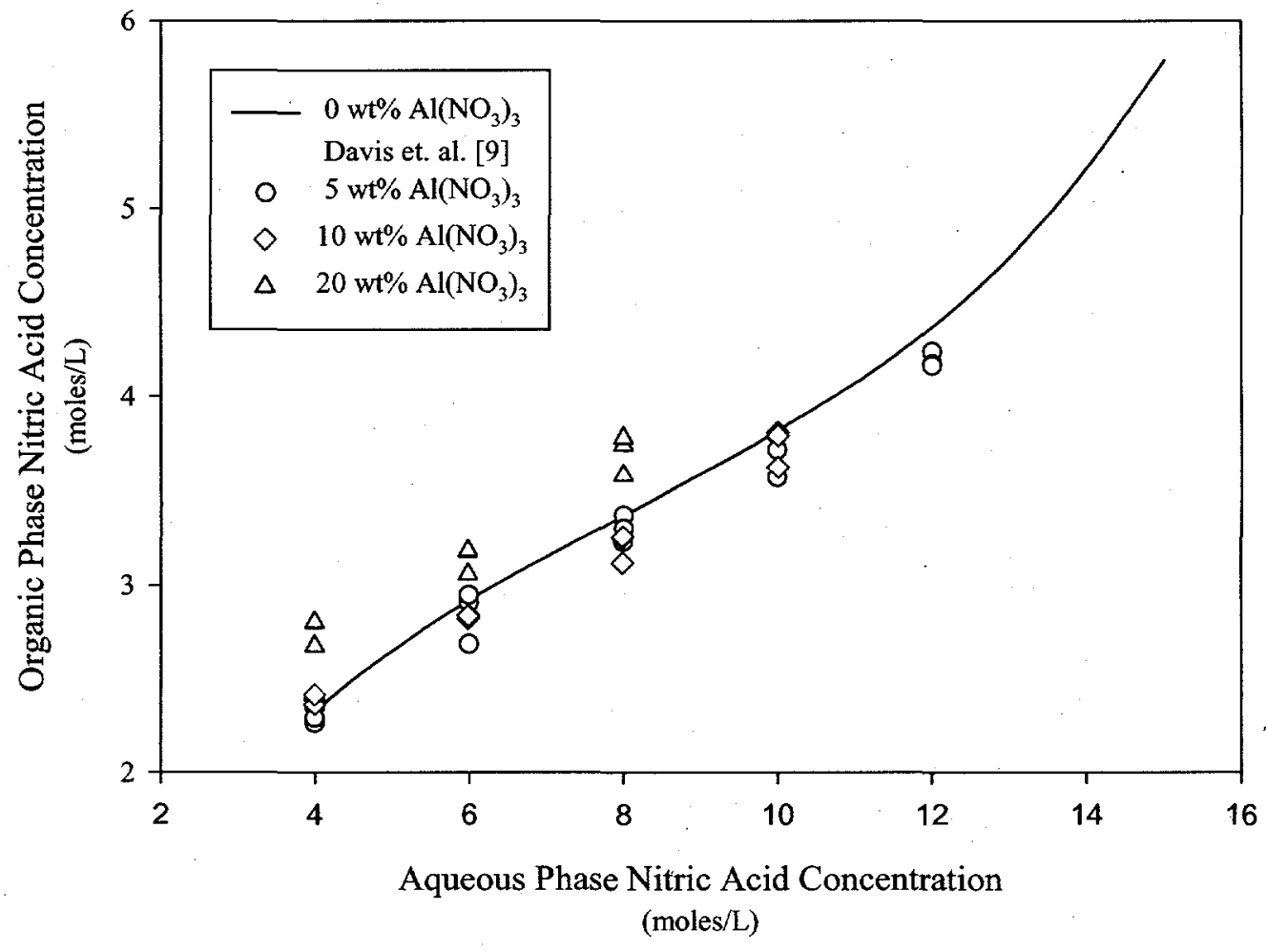


This page was intentionally left blank. 
Figure 9 Correlation of Runaway Reaction Initiation Temperature with Extracted Nitric Acid Concentration

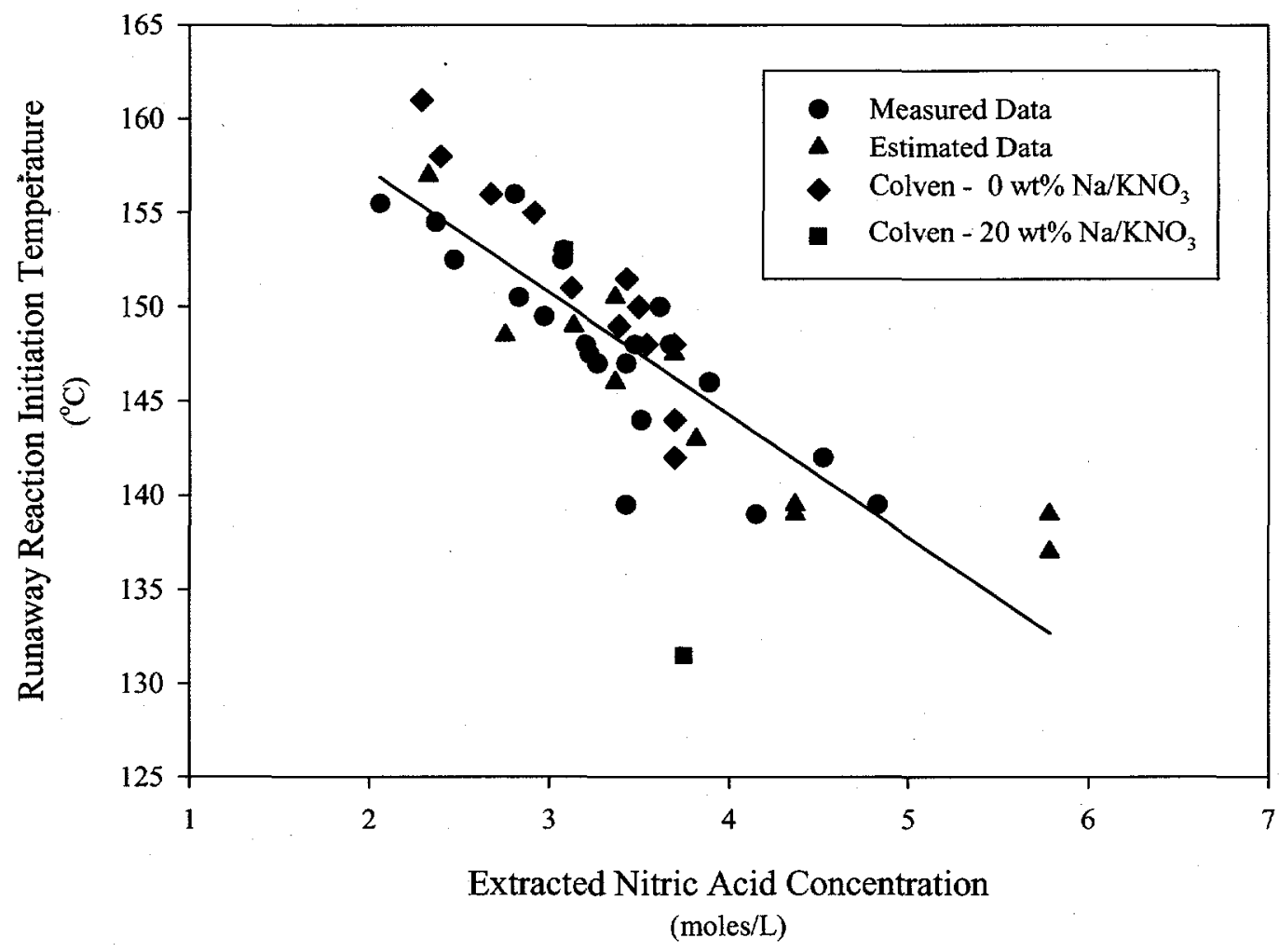


This page was intentionally left blank. 
Figure 10 Solubility of Metal Nitrate Salts in Nitric Acid

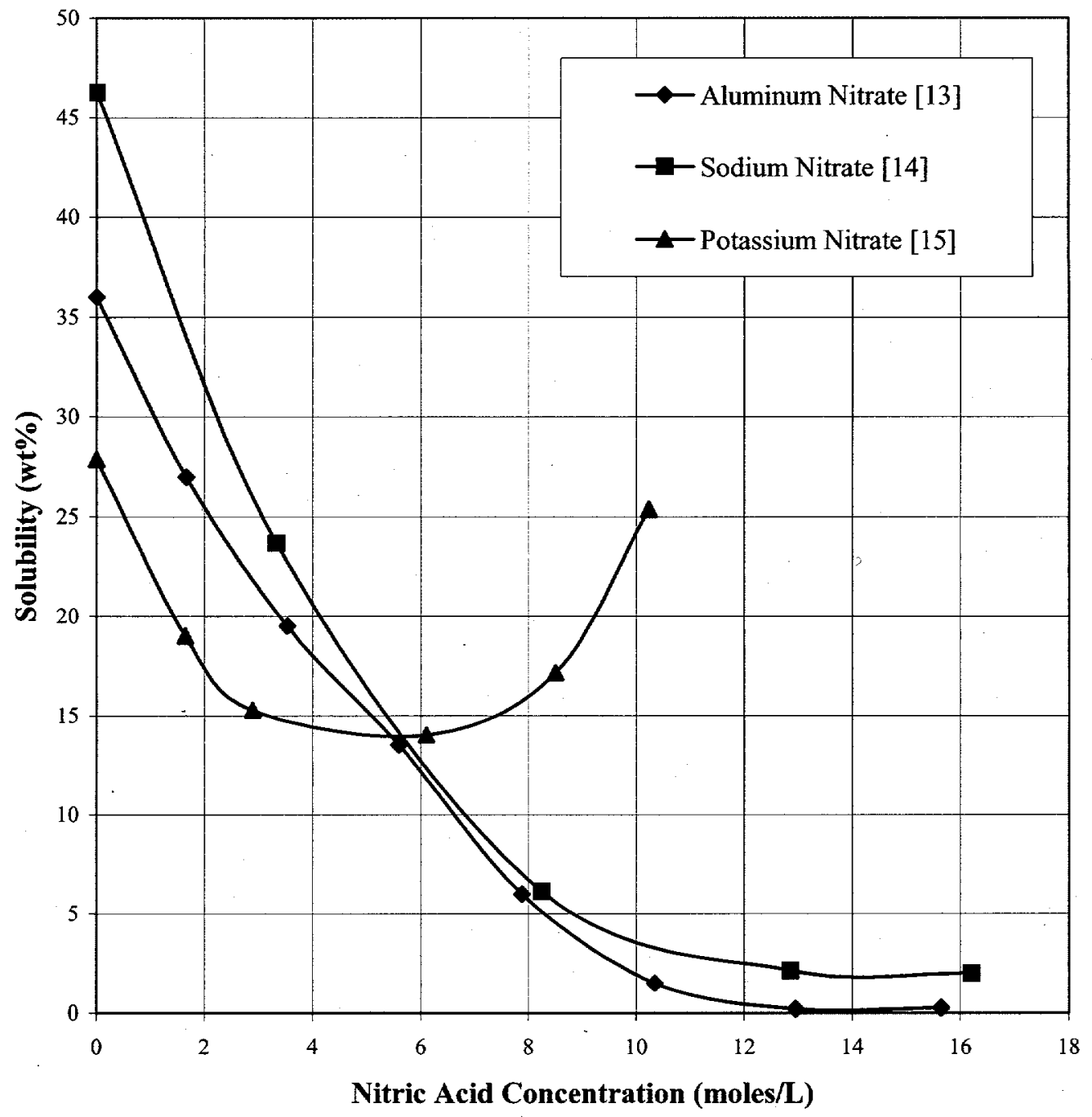




\section{This page was intentionally left blank.}




\title{
Appendix A Reagent Data and Properties
}

\section{$\underline{\text { Reagents }}$}

The reagents used to prepare the solutions for the runaway TBP/nitric acid reaction initiation temperature measurements are described below.

Tributyl Phosphate

Manufacturer: Aldrich Chemical Company

Lot Number: $14628 \mathrm{ER}$

Purity: $99+\%$

Nitric Acid $\left(\mathrm{HNO}_{3}\right)$

Concentration: $69.7 \mathrm{wt} \%$

Manufacturer: Fisher Chemicals

Lot Number: 993625

\author{
Aluminum Nitrate Crystals $\left(\mathrm{Al}\left(\mathrm{NO}_{3}\right)_{3} \cdot 9 \mathrm{H}_{2} \mathrm{O}\right.$ \\ Manufacturer: Fisher Chemicals \\ Lot Number: 990207 \\ Assay: $98.1 \%$ \\ Sodium Nitrate $\left(\mathrm{NaNO}_{3}\right)$ \\ Manufacturer: Fisher Chemicals \\ Lot Number: 94164413 \\ Assay: $100.1 \%$ \\ Potassium Nitrate $\left(\mathrm{KNO}_{3}\right)$ \\ Manufacturer: Mallinckrodt Specialty Chemicals Co. \\ Lot Number: 7028KLCM \\ Assay: Meets ACS Specification
}

\section{$\underline{\text { Nitric Acid Concentration/Density }}$}

The concentration of the nitric acid used to prepare the aqueous phase solutions for the runaway reaction studies was measured by titration. The data from these measurements are summarized in Table A.1.

The density of the nitric acid was measured by transferring a $1 \mathrm{~mL}$ aliquot of solution using a calibrated pipette to a preweighed (tared) beaker. A new pipette tip was used for each of 10 measurements. The pipette tip was conditioned with the acid one time before making the transfer. The data from these measurements are given in Table A.2. 
Table A.1 Actual Concentration of $70 \mathrm{wt} \%$ Nitric Acid

\begin{tabular}{ccc}
\hline \hline Sample Number & $\begin{array}{c}\text { Nominal Concentration } \\
(\mathrm{wt} \% / \mathrm{M})\end{array}$ & $\begin{array}{c}\text { Measured Concentration } \\
(\mathrm{M})\end{array}$ \\
\hline 1 & $70 / 15.7$ & 15.2786 \\
2 & $70 / 15.7$ & 15.2948 \\
3 & $70 / 15.7$ & 15.1691 \\
4 & $70 / 15.7$ & 15.0881 \\
5 & $70 / 15.7$ & 15.1604 \\
& & \\
& Average & 15.1982 \\
& Standard Deviation & 0.0869 \\
& 95\% Confidence Limit & 0.1079 \\
\hline
\end{tabular}

Table A.2 Density of 70 wt $\%$ Nitric Acid

\begin{tabular}{ccc}
\hline \hline Sample Number & $\begin{array}{c}\text { Nitric Acid Mass } \\
(\mathrm{g})\end{array}$ & $\begin{array}{c}\text { Nitric Acid Density } \\
(\mathrm{g} / \mathrm{mL})\end{array}$ \\
\hline 1 & 1.4029 & 1.3934 \\
2 & 1.4045 & 1.3950 \\
3 & 1.4020 & 1.3925 \\
4 & 1.4040 & 1.3945 \\
5 & 1.4055 & 1.3960 \\
6 & 1.4064 & 1.3969 \\
7 & 1.4041 & 1.3946 \\
8 & 1.4041 & 1.3946 \\
9 & 1.4036 & 1.3941 \\
10 & 1.4053 & 1.3950 \\
& & 1.3947 \\
& Average & 0.0012 \\
& Standard Deviation & 0.0008 \\
\hline
\end{tabular}

(1) Transfer Volume of Calibrated Pipette $-1.00683 \pm 0.0015 \mathrm{~mL}$

\section{Distribution of Nitric Acid Between Aqueous and 100\% TBP Phases}

Data summarizing the distribution of nitric acid between the aqueous and $100 \%$ TBP phases are summarized in Table A.3. The data presented in the table were based on experimentally determined values which were empirically smoothed to reduce scatter.[9] 
Table A.3 Distribution of Nitric Acid Between Aqueous and 100\% TBP Phases

\begin{tabular}{|c|c|c|c|c|c|}
\hline \multicolumn{2}{|c|}{ Aqueous Phase } & \multicolumn{4}{|c|}{ Organic Phase } \\
\hline Nitric Acid & Density & Nitric Acid & Water & TBP & Density \\
\hline $\begin{array}{c}\text { Conc. } \\
(\text { moles } / L)\end{array}$ & $\begin{array}{l}25^{\circ} \mathrm{C} \\
(\mathrm{g} / \mathrm{mL})\end{array}$ & $\begin{array}{c}\text { Conc. } \\
(\text { moles } / \mathrm{L})\end{array}$ & $\begin{array}{c}\text { Conc. } \\
\text { (moles } / \mathrm{L})\end{array}$ & $\begin{array}{c}\text { Conc. } \\
\text { (moles } / \mathrm{L})\end{array}$ & $\begin{array}{l}25^{\circ} \mathrm{C} \\
(\mathrm{g} / \mathrm{mL})\end{array}$ \\
\hline 0.100 & 1.0002 & 0.032 & 3.59 & 3.420 & 0.9774 \\
\hline 0.200 & 1.0034 & 0.105 & 3.58 & 3.411 & 0.9795 \\
\hline 0.300 & 1.0066 & 0.201 & 3.57 & 3.396 & 0.9815 \\
\hline 0.400 & 1.0098 & 0.304 & 3.54 & 3.383 & 0.9838 \\
\hline 0.500 & 1.0131 & 0.409 & 3.52 & 3.367 & 0.9860 \\
\hline 0.600 & 1.0164 & 0.513 & 3.47 & 3.356 & 0.9885 \\
\hline 0.700 & 1.0196 & 0.617 & 3.43 & 3.344 & 0.9912 \\
\hline 0.800 & 1.0229 & 0.709 & 3.39 & 3.331 & 0.9928 \\
\hline 0.900 & 1.0263 & 0.796 & 3.35 & 3.320 & 0.9948 \\
\hline 1.000 & 1.0296 & 0.870 & 3.32 & 3.312 & 0.9968 \\
\hline 1.500 & 1.0462 & 1.185 & 3.08 & 3.282 & 1.0042 \\
\hline 2.000 & 1.0627 & 1.480 & 2.76 & 2.257 & 1.0105 \\
\hline 2.500 & 1.0792 & 1.733 & 2.50 & 3.234 & 1.0156 \\
\hline 3.000 & 1.0955 & 1.950 & 2.30 & 3.213 & 1.0200 \\
\hline 3.500 & 1.1116 & 2.150 & 2.12 & 3.191 & 1.0236 \\
\hline 4.000 & 1.1276 & 2.330 & 1.95 & 3.172 & 1.0268 \\
\hline 4.500 & 1.1432 & 2.500 & 1.79 & 3.153 & 1.0296 \\
\hline 5.000 & 1.1586 & 2.650 & 1.65 & 3.136 & 1.0320 \\
\hline 5.500 & 1.1738 & 2.790 & 1.52 & 3.120 & 1.0342 \\
\hline 6.000 & 1.1886 & 2.920 & 1.40 & 3.105 & 1.0362 \\
\hline 6.500 & 1.2032 & 3.040 & 1.31 & 3.090 & 1.0382 \\
\hline 7.000 & 1.2174 & 3.150 & 1.25 & 3.076 & 1.0402 \\
\hline 7.500 & 1.2313 & 3.260 & 1.22 & 3.059 & 1.0422 \\
\hline 8.000 & 1.2449 & 3.370 & 1.20 & 3.043 & 1.0445 \\
\hline 8.500 & 1.2581 & 3.480 & 1.20 & 3.026 & 1.0468 \\
\hline 9.000 & 1.2710 & 3.590 & 1.20 & 3.009 & 1.0492 \\
\hline 9.500 & 1.2835 & 3.700 & 1.22 & 2.991 & 1.0518 \\
\hline 10.000 & 1.2957 & 3.820 & 1.24 & 2.970 & 1.0540 \\
\hline 11.000 & 1.3189 & 4.070 & 1.31 & 2.926 & 1.0594 \\
\hline 12.000 & 1.3406 & 4.370 & 1.41 & 2.872 & 1.0657 \\
\hline 13.000 & 1.3608 & 4.740 & 1.53 & 2.808 & 1.0742 \\
\hline 14.000 & 1.3795 & 5.220 & 1.69 & 2.723 & 1.0845 \\
\hline 15.000 & 1.3965 & 5.790 & 2.00 & 2.608 & 1.0955 \\
\hline
\end{tabular}


This page was intentionally left blank. 
WSRC-TR-2000-00427

Revision 0

\section{Appendix B Preparation of TBP/Nitric Acid Solutions}

The target concentrations and the amounts of materials used to prepare the aqueous and organic phases for each of the RSST ${ }^{\mathrm{TM}}$ experiments are provided in Table B.1 for open experiments and Table B.2 for closed experiments.

Table B.1 Preparation of Aqueous and Organic Phases for Open RSST'M Experiments

\begin{tabular}{|c|c|c|c|c|c|c|c|c|}
\hline \multirow[t]{2}{*}{ Run No. } & \multicolumn{2}{|c|}{ Target Concentrations } & \multirow{2}{*}{$\begin{array}{c}\mathrm{Al}\left(\mathrm{NO}_{3}\right)_{3} \cdot 9 \mathrm{H}_{2} \mathrm{O} \\
\text { Mass } \\
(\mathrm{g})\end{array}$} & \multirow{2}{*}{$\begin{array}{l}\text { Water } \\
\text { Mass } \\
(\mathrm{g})\end{array}$} & \multirow{2}{*}{$\begin{array}{c}\text { Nitric Acid } \\
\text { Mass } \\
\text { (g) }\end{array}$} & \multicolumn{2}{|c|}{ Actual Concentrations } & \multirow{2}{*}{$\begin{array}{c}\text { TBP } \\
\text { Mass } \\
(\mathrm{g})\end{array}$} \\
\hline & $\begin{array}{c}\text { Nitric Acid } \\
(\text { moles } / \mathrm{L})\end{array}$ & $\begin{array}{c}\mathrm{Al}\left(\mathrm{NO}_{3}\right)_{3} \\
(\mathrm{wt} \%) \\
\end{array}$ & & & & $\begin{array}{l}\text { Nitric Acid } \\
\text { (moles } / \mathrm{L})\end{array}$ & $\begin{array}{c}\mathrm{Al}\left(\mathrm{NO}_{3}\right)_{3} \\
(\mathrm{wt} \%) \\
\end{array}$ & \\
\hline TBP $0 / 2-1$ & 2 & 0 & 0 & 52.683 & 11.097 & 2.00 & 0 & 11.513 \\
\hline TBP 0/8-1 & 8 & 0 & 0 & 30.362 & 44.367 & 8.00 & 0 & 12.010 \\
\hline TBP 0/15-1 & 15 & 0 & 0 & 0.648 & 83.198 & 15.00 & 0 & 12.014 \\
\hline TBP 5/4-1 & 4 & 5 & 6.274 & 42.793 & 23.010 & 4.11 & 4.94 & 11.483 \\
\hline TBP 5/4-2 & 4 & 5 & 6.299 & 42.796 & 22.193 & 4.00 & 5.02 & 12.022 \\
\hline TBP 5/4-3 & 4 & 5 & 6.296 & 42.771 & 22.202 & 4.00 & 5.02 & 11.584 \\
\hline TBP $5 / 4-4^{(1)}$ & 4 & 5 & 3.564 & 45.502 & 22.217 & 4.00 & 5.00 & 11.596 \\
\hline TBP 5/4-5 & 4 & 5 & 6.286 & 42.799 & 22.184 & 4.00 & 5.01 & 11.580 \\
\hline TBP 5/4-6 & 4 & 5 & 6.280 & 42.818 & 22.178 & 4.00 & 5.00 & 11.594 \\
\hline TBP 5/6-1 & 6 & 5 & 6.615 & 35.240 & 33.289 & 6.00 & 5.00 & 12.013 \\
\hline TBP 5/12-1 & 12 & 5 & 7.472 & 12.611 & 64.665 & 11.57 & 5.01 & 12.010 \\
\hline TBP 5/12-2 & 12 & 5 & 7.457 & 12.630 & 64.649 & 11.57 & 5.00 & 12.014 \\
\hline
\end{tabular}

(1) $\mathrm{NaNO}_{3}$ used as Dissolved Solid 
Table B.2 Preparation of Aqueous and Organic Phases for Closed RSST ${ }^{\mathrm{TM}}$ Experiments

\begin{tabular}{|c|c|c|c|c|c|c|c|c|}
\hline \multirow[t]{2}{*}{ Run No. } & \multicolumn{2}{|c|}{ Target Concentrations } & \multirow{2}{*}{$\begin{array}{c}\mathrm{Al}\left(\mathrm{NO}_{3}\right)_{3} \cdot 9 \mathrm{H}_{2} \mathrm{O} \\
\text { Mass } \\
\text { (g) } \\
\end{array}$} & \multirow{2}{*}{$\begin{array}{l}\text { Water } \\
\text { Mass } \\
(\mathrm{g})\end{array}$} & \multirow{2}{*}{$\begin{array}{l}\text { Nitric Acid } \\
\text { Mass } \\
\text { (g) } \\
\end{array}$} & \multicolumn{2}{|c|}{ Actual Concentrations } & \multirow{2}{*}{$\begin{array}{c}\text { TBP } \\
\text { Mass } \\
(\mathrm{g}) \\
\end{array}$} \\
\hline & $\begin{array}{c}\text { Nitric Acid } \\
(\text { moles } / \mathrm{L})\end{array}$ & $\begin{array}{c}\mathrm{Al}\left(\mathrm{NO}_{3}\right)_{3} \\
(\mathrm{wt} \%) \\
\end{array}$ & & & & $\begin{array}{c}\text { Nitric Acid } \\
(\text { moles } / \mathrm{L})\end{array}$ & $\begin{array}{c}\mathrm{Al}\left(\mathrm{NO}_{3}\right)_{3} \\
(\mathrm{wt} \%) \\
\end{array}$ & \\
\hline TBP 0/0-1 & 0 & 0 & 0 & 0 & 0 & 0 & 0 & 11.834 \\
\hline TBP 0/4-3 & 4 & 0 & 22.190 & 45.495 & 0 & 4.00 & 0 & 11.547 \\
\hline TBP 0/8-2 & 8 & 0 & 44.352 & 30.362 & 0 & 8.00 & 0 & 11.563 \\
\hline TBP $0 / 8-3^{(3)}$ & 8 & 0 & 44.364 & 30.364 & 0 & 8.00 & 0 & 11.498 \\
\hline TBP 0/10-1 & 10 & 0 & 55.438 & 22.322 & 0 & 10.00 & 0 & 11.508 \\
\hline TBP 0/12-1 & 12 & 0 & 66.610 & 13.922 & 0 & 12.00 & 0 & 11.532 \\
\hline TBP 0/13-1 & 13 & 0 & 72.213 & 9.592 & 0 & 13.00 & 0 & 11.509 \\
\hline TBP 0/14-1 & 14 & 0 & 77.680 & 5.162 & 0 & 14.00 & 0 & 11.526 \\
\hline TBP $0 / 15-2$ & 15 & 0 & 83.172 & 0.680 & 0 & 14.99 & 0 & 11.575 \\
\hline TBP $0 / 15-3$ & 15 & 0 & 83.159 & 0.646 & 0 & 15.00 & 0 & 11.525 \\
\hline TBP 5/4-7 & 4 & 5 & 22.181 & 42.802 & 6.274 & 4.00 & 5.00 & 11.580 \\
\hline TBP 5/4-8 & 4 & 5 & 22.190 & 42.782 & 6.279 & 4.00 & 5.00 & 11.536 \\
\hline TBP 5/6-2 & 6 & 5 & 33.283 & 35.232 & 6.617 & 6.00 & 5.00 & 11.536 \\
\hline TBP 5/8-1 & 8 & 5 & 44.353 & 27.369 & 6.926 & 8.00 & 5.00 & 11.508 \\
\hline TBP $5 / 8-2^{(1)}$ & 8 & 5 & 44.353 & 30.356 & 3.949 & 8.00 & 5.02 & 11.514 \\
\hline TBP 5/10-1 & 10 & 5 & 55.448 & 19.204 & 7.208 & 10.00 & 5.00 & 11.520 \\
\hline TBP 5/12-3 & 12 & 5 & 66.531 & 10.716 & 7.462 & 11.99 & 5.00 & 11.523 \\
\hline TBP $5 / 12-4^{(4)}$ & 12 & 5 & 66.532 & 10.694 & 7.469 & 12.00 & 5.01 & 11.536 \\
\hline TBP 10/4-1 & 4 & 10 & 22.205 & 39.769 & 13.268 & 4.00 & 10.01 & 11.534 \\
\hline TBP $10 / 4-2^{(2)}$ & 4 & 10 & 22.197 & 45.497 & 7.520 & 4.00 & 10.00 & 11.524 \\
\hline TBP 10/6-1 & 6 & 10 & 33.282 & 32.029 & 13.983 & 6.00 & 10.01 & 11.525 \\
\hline
\end{tabular}

(1) $\mathrm{NaNO}_{3}$ used as Dissolved Solid

(2) KNO3 used as Dissolved Solid

(3) Two Phase Experiment (Aqueous and Organic)

(4) Three Phase Experiment (Aqueous, Organic, and Solid $\mathrm{Al}\left(\mathrm{NO}_{3}\right)_{3}$ )

(5) Precipitation Occurred 
WSRC-TR-2000-00427

Revision 0

Table B.2 Continued

\begin{tabular}{|c|c|c|c|c|c|c|c|c|}
\hline \multirow[t]{2}{*}{ Run No. } & \multicolumn{2}{|c|}{ Target Concentrations } & \multirow{2}{*}{$\begin{array}{c}\mathrm{Al}\left(\mathrm{NO}_{3}\right)_{3} \cdot 9 \mathrm{H}_{2} \mathrm{O} \\
\text { Mass } \\
(\mathrm{g})\end{array}$} & \multirow{2}{*}{$\begin{array}{c}\text { Water } \\
\text { Mass } \\
\text { (g) }\end{array}$} & \multirow{2}{*}{$\begin{array}{c}\text { Nitric Acid } \\
\text { Mass } \\
\text { (g) }\end{array}$} & \multicolumn{2}{|c|}{ Actual Concentrations } & \multirow{2}{*}{$\begin{array}{c}\text { TBP } \\
\text { Mass } \\
(\mathrm{g})\end{array}$} \\
\hline & $\begin{array}{l}\text { Nitric Acid } \\
\text { (moles } / \mathrm{L})\end{array}$ & $\begin{array}{c}\mathrm{Al}\left(\mathrm{NO}_{3}\right)_{3} \\
(\mathrm{wt} \%)\end{array}$ & & & & $\begin{array}{l}\text { Nitric Acid } \\
(\text { moles } / \mathrm{L})\end{array}$ & $\begin{array}{c}\mathrm{Al}\left(\mathrm{NO}_{3}\right)_{3} \\
(\mathrm{wt} \%)\end{array}$ & \\
\hline TBP $10 / 8-1$ & 8 & 10 & 44.352 & 24.034 & 14.629 & 8.00 & 10.01 & 11.528 \\
\hline TBP $10 / 8-2^{(1)}$ & 8 & 10 & 44.366 & 30.350 & 8.309 & 8.00 & 10.01 & 11.541 \\
\hline TBP 10/9-1 & 9 & 10 & 49.894 & 19.953 & 14.941 & 8.99 & 10.01 & 11.518 \\
\hline TBP $10 / 10-1$ & 10 & 10 & 55.440 & 15.754 & 15.216 & 10.00 & 10.00 & 11.536 \\
\hline TBP $10 / 10-2$ & 10 & 10 & 55.480 & 15.734 & 15.224 & 10.00 & 10.00 & 11.509 \\
\hline TBP 20/4-1 & 4 & 20 & 22.188 & 32.619 & 29.797 & 4.00 & 20.00 & 11.512 \\
\hline TBP 20/4-2 & 4 & 20 & 22.186 & 32.633 & 29.791 & 4.00 & 19.99 & 11.545 \\
\hline TBP $20 / 4-3^{(2,5)}$ & 4 & 20 & 22.201 & 45.489 & 16.921 & 4.00 & 20.00 & 11.528 \\
\hline TBP $20 / 4-4^{(2,5)}$ & 4 & 20 & 22.643 & 45.510 & 19.920 & 4.06 & 22.62 & 11.518 \\
\hline TBP 20/6-1 & 6 & 20 & 33.264 & 24.493 & 31.413 & 6.00 & 20.00 & 11.528 \\
\hline TBP 20/6-2 & 6 & 20 & 33.265 & 24.498 & 31.419 & 6.00 & 20.00 & 11.549 \\
\hline TBP 20/6-3 & 6 & 20 & 33.279 & 24.499 & 31.404 & 6.00 & 19.99 & 11.524 \\
\hline TBP 20/7-1 & 7 & 20 & 38.806 & 20.352 & 32.166 & 7.00 & 20.00 & 11.535 \\
\hline TBP $20 / 7-2^{(5)}$ & 7 & 20 & 38.824 & 20.340 & 32.165 & 7.00 & 20.00 & 11.520 \\
\hline TВP 20/7-3 & 7 & 20 & 38.809 & 20.350 & 32.169 & 7.00 & 20.00 & 11.529 \\
\hline TBP 20/7-4 & 7 & 20 & 38.811 & 20.344 & 32.168 & 7.00 & 20.00 & 11.517 \\
\hline TBP 20/8-1 & 8 & 20 & 44.352 & 16.148 & 32.898 & 8.00 & 20.00 & 11.520 \\
\hline TBP $20 / 8-2^{(5)}$ & 8 & 20 & 44.354 & 16.130 & 32.889 & 8.00 & 20.00 & 11.530 \\
\hline TBP $20 / 8-3^{(2,5)}$ & 8 & 20 & 44.351 & 30.374 & 18.677 & 8.00 & 20.00 & 11.520 \\
\hline TBP $20 / 8-4^{(5)}$ & 8 & 20 & 44.398 & 16.162 & 32.892 & 8.00 & 19.98 & 11.514 \\
\hline TBP $20 / 10-1^{(2,5)}$ & 10 & 20 & 55.445 & 22.310 & 19.445 & 10.00 & 20.01 & 11.533 \\
\hline TBP $20 / 10-2^{(2,5)}$ & 10 & 20 & 110.899 & 44.613 & 38.873 & 10.00 & 20.00 & 11.523 \\
\hline $\begin{array}{l}\text { (1) } \mathrm{NaNO}_{3} \text { used as Dis } \\
\text { (2) } \mathrm{KNO}_{3} \text { used as Diss } \\
\text { (3) Two Phase Experir } \\
\text { (4) Three Phase Exper } \\
\text { (5) Precipitation Occu }\end{array}$ & $\begin{array}{l}\text { ved Solid } \\
\text { ed Solid } \\
\text { t (Aqueous } \\
\text { nt (Aqueous }\end{array}$ & $\begin{array}{l}\text { anic) } \\
\text { ic, and }\end{array}$ & $\left.\mathrm{NO}_{3}\right)_{3}$ ) & & & & & \\
\hline
\end{tabular}


The mass of TBP used in each RSST ${ }^{\mathrm{TM}}$ experiment is provided in Table B.3 for open system experiments and Table B.4 for closed system experiments.

Table B.3 Mass of TBP Used for Open RSST ${ }^{\mathrm{TM}}$ Experiments

\begin{tabular}{lccc}
\hline \hline Run No. & $\begin{array}{c}\text { Aqueous Phase Concentrations } \\
\text { Nitric Acid } \\
(\text { moles/L) }\end{array}$ & $\begin{array}{c}\text { TBP Added to } \\
\left(\mathrm{NO}_{3}\right)_{3}\end{array}$ & $\begin{array}{c}\text { TSS } \\
\text { RSST }^{\text {TM }} \text { Test Cell } \\
(\mathrm{g})\end{array}$ \\
\hline TBP 0/2-1 & 2.00 & 0 & 10.21 \\
TBP 0/8-1 & 8.00 & 0 & 10.48 \\
TBP 0/15-1 & 15.00 & 0 & 11.03 \\
TBP 5/4-1 & 4.11 & 4.94 & 10.40 \\
TBP 5/4-2 & 4.00 & 5.02 & 10.37 \\
TBP 5/4-3 & 4.00 & 5.02 & 10.38 \\
TBP 5/4-4 & 4.00 & 5.00 & 10.40 \\
TBP 5/4-5 & 4.00 & 5.01 & 10.41 \\
TBP 5/4-6 & 4.00 & 5.00 & 10.38 \\
TBP 5/6-1 & 6.00 & 5.00 & 10.40 \\
TBP 5/12-1 & 11.57 & 5.01 & 10.76 \\
TBP 5/12-2 & 11.57 & 5.00 & 10.76 \\
\hline
\end{tabular}

(1) $\mathrm{NaNO}_{3}$ used as Dissolved Solid

Table B.4 Mass of TBP Used for Closed RSST ${ }^{\mathrm{TM}}$ Experiments

\begin{tabular}{|c|c|c|c|}
\hline \multirow[t]{2}{*}{ Run No. } & \multicolumn{2}{|c|}{ Aqueous Phase Concentrations } & \multirow{2}{*}{$\begin{array}{l}\text { TBP Added to } \\
\text { RSST }^{\mathrm{TM}} \text { Test Cell } \\
(\mathrm{g})\end{array}$} \\
\hline & $\begin{array}{c}\text { Nitric Acid } \\
(\text { moles } / L)\end{array}$ & $\begin{array}{c}\mathrm{Al}\left(\mathrm{NO}_{3}\right)_{3} \\
(\mathrm{wt} \%)\end{array}$ & \\
\hline TBP $0 / 0-1$ & 0 & 0 & 9.65 \\
\hline TBP 0/4-3 & 4.00 & 0 & 10.40 \\
\hline TBP 0/8-2 & 8.00 & 0 & 10.54 \\
\hline TBP 0/8-3 $3^{(1)}$ & 8.00 & 0 & 9.40 \\
\hline TBP 0/10-1 & 10.00 & 0 & 10.47 \\
\hline TBP 0/12-1 & 12.00 & 0 & 10.63 \\
\hline TBP 0/13-1 & 13.00 & 0 & 10.81 \\
\hline TBP 0/14-1 & 14.00 & 0 & 10.16 \\
\hline TBP $0 / 15-2$ & 14.99 & 0 & 11.04 \\
\hline TBP 0/15-3 & 15.00 & 0 & 11.02 \\
\hline
\end{tabular}

(1) Two Phase Experiment - Mass of Aqueous Phase was $1.24 \mathrm{~g}$

(2) $\mathrm{NaNO}_{3}$ used as Dissolved Solid

(3) Three Phase Experiment - Mass of Aqueous Phase was $1.30 \mathrm{~g}$ (Mass of Solids was not Measured)

(4) $\mathrm{KNO}_{3}$ used as Dissolved Solid

(5) Precipitation Occurred 
Table B.4 Continued

\begin{tabular}{|c|c|c|c|}
\hline \multirow[t]{2}{*}{ Run No. } & \multicolumn{2}{|c|}{ Aqueous Phase Concentrations } & \multirow{2}{*}{$\begin{array}{l}\text { TBP Added to } \\
\text { RSST TM Test Cell }^{\text {T }} \\
\text { (g) }\end{array}$} \\
\hline & $\begin{array}{c}\text { Nitric Acid } \\
\text { (moles } / \mathrm{L})\end{array}$ & $\begin{array}{c}\mathrm{Al}\left(\mathrm{NO}_{3}\right)_{3} \\
(\mathrm{wt} \%)\end{array}$ & \\
\hline TBP 5/4-7 & 4.00 & 5.00 & 10.41 \\
\hline TBP 5/4-8 & 4.00 & 5.00 & 10.36 \\
\hline TBP $5 / 6-2$ & 6.00 & 5.00 & 10.40 \\
\hline TBP $5 / 8-1$ & 8.00 & 5.00 & 10.49 \\
\hline TBP $5 / 8-2^{(2)}$ & 8.00 & 5.02 & 10.43 \\
\hline TBP 5/10-1 & 10.00 & 5.00 & 10.60 \\
\hline TBP $5 / 12-3$ & 11.99 & 5.00 & 10.81 \\
\hline TBP $5 / 12-4^{(3)}$ & 12.00 & 5.01 & 9.63 \\
\hline TBP $10 / 4-1$ & 4.00 & 10.01 & 10.39 \\
\hline TBP $10 / 4-2^{(4)}$ & 4.00 & 10.00 & 10.35 \\
\hline TBP $10 / 6-1$ & 6.00 & 10.01 & 10.41 \\
\hline TBP $10 / 8-1$ & 8.00 & 10.01 & 10.54 \\
\hline TBP $10 / 8-2^{(2)}$ & 8.00 & 10.01 & 10.46 \\
\hline TBP $10 / 9-1$ & 8.99 & 10.01 & 1049 \\
\hline TBP 10/10-1 & 10.00 & 10.00 & 10.66 \\
\hline TBP 10/10-2 & 10.00 & 10.00 & 10.65 \\
\hline TBP 20/4-1 & 4.00 & 20.00 & 10.43 \\
\hline TBP 20/4-2 & 4.00 & 19.99 & 10.37 \\
\hline TBP $20 / 4-3^{(4,5)}$ & 4.00 & 20.00 & N/A \\
\hline TBP $20 / 4-4^{(4,5)}$ & 4.06 & 22.62 & $\mathrm{~B} / \mathrm{A}$ \\
\hline TBP 20/6-1 & 6.00 & 20.00 & 10.53 \\
\hline TBP 20/6-2 & 6.00 & 20.00 & 10.46 \\
\hline TBP 20/6-3 & 6.00 & 19.99 & 10.46 \\
\hline TBP 20/7-1 & 7.00 & 20.00 & 10.49 \\
\hline TBP $20 / 7-2^{(5)}$ & 7.00 & 20.00 & N/A \\
\hline TBP $20 / 7-3$ & 7.00 & 20.00 & 10.52 \\
\hline TBP $20 / 7-4$ & 7.00 & 20.00 & 10.34 \\
\hline TBP 20/8-1 & 8.00 & 20.00 & 10.43 \\
\hline TBP 20/8-2 & 8.00 & 20.00 & N/A \\
\hline TBP $20 / 8-3^{(4,5)}$ & 8.00 & 20.00 & N/A \\
\hline TBP $20 / 8-4^{(5)}$ & 8.00 & 19.98 & N/A \\
\hline TBP 20/10-1 $1^{(4,5)}$ & 10.00 & 20.01 & N/A \\
\hline TBP $20 / 10-2^{(4,5)}$ & 10.00 & 20.00 & N/A \\
\hline
\end{tabular}

(1) Two Phase Experiment - Mass of Aqueous Phase was $1.24 \mathrm{~g}$

(2) $\mathrm{NaNO}_{3}$ used as Dissolved Solid

(3) Three Phase Experiment - Mass of Aqueous Phase was $1.30 \mathrm{~g}$ (Mass of Solids was not Measured)

(4) $\mathrm{KNO}_{3}$ used as Dissolved Solid

(5) Precipitation Occurred 
This page was intentionally left blank. 
WSRC-TR-2000-00427

Revision 0

Appendix C Temperature Profiles and Self-Heating Rates for Open RSST ${ }^{\mathrm{m}}$ Experiments 
This page was intentionally left blank. 
Figure C.1 Temperature Profile and Self-Heating Rate for Run No. TBP 5/12-1
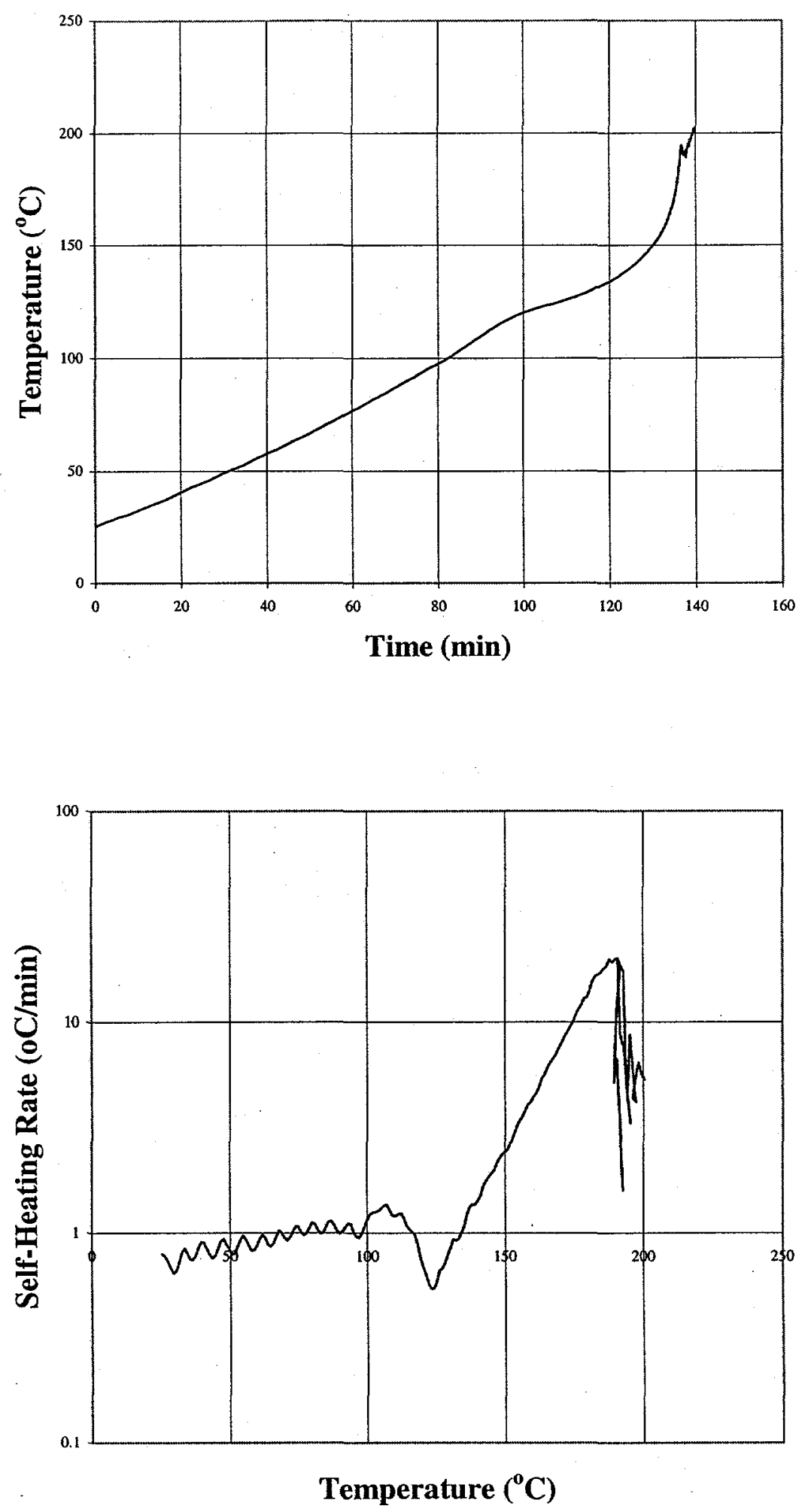
Figure C.2 Temperature Profile and Self-Heating Rate for Run No. TBP 5/12-2
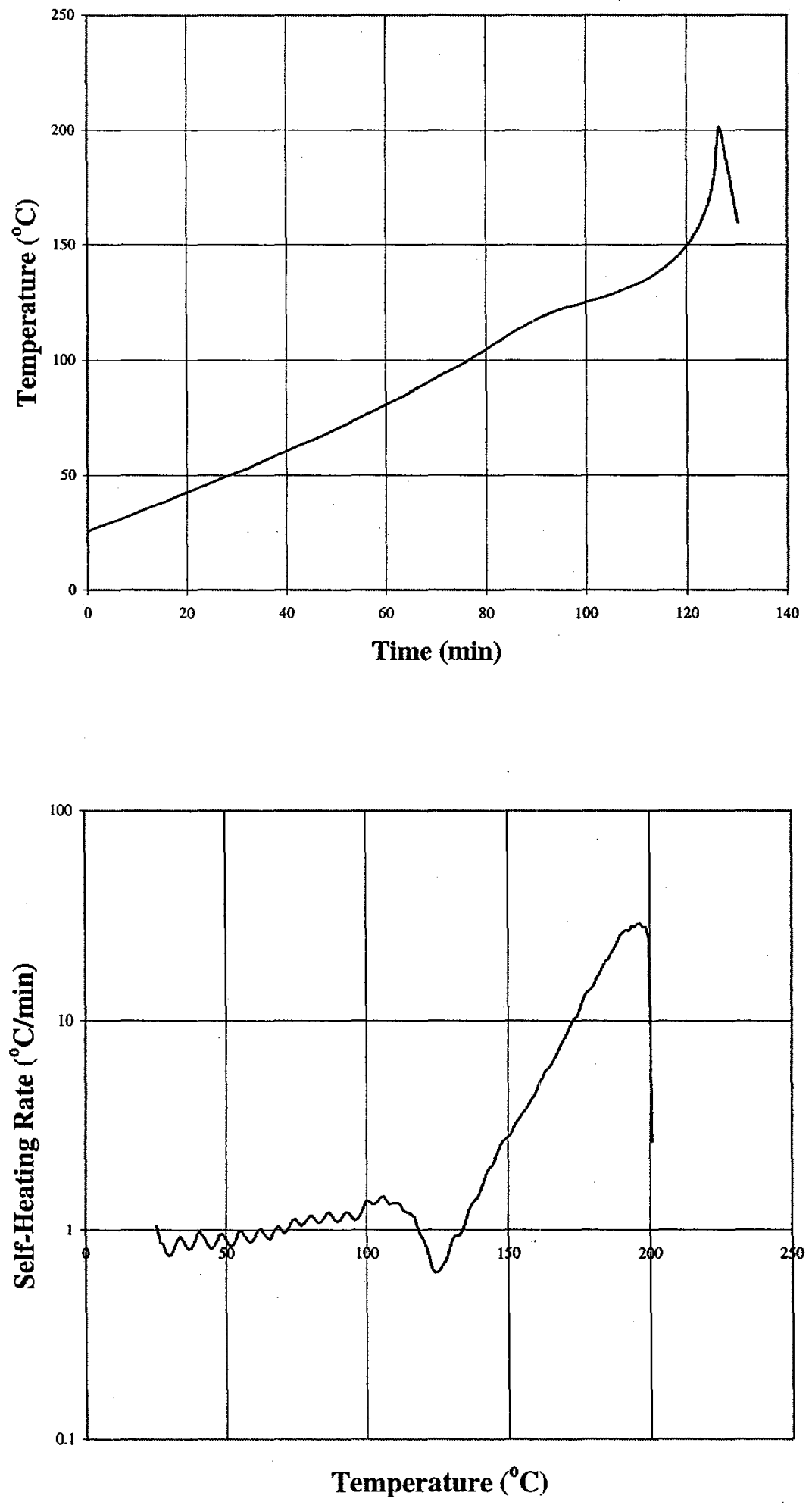

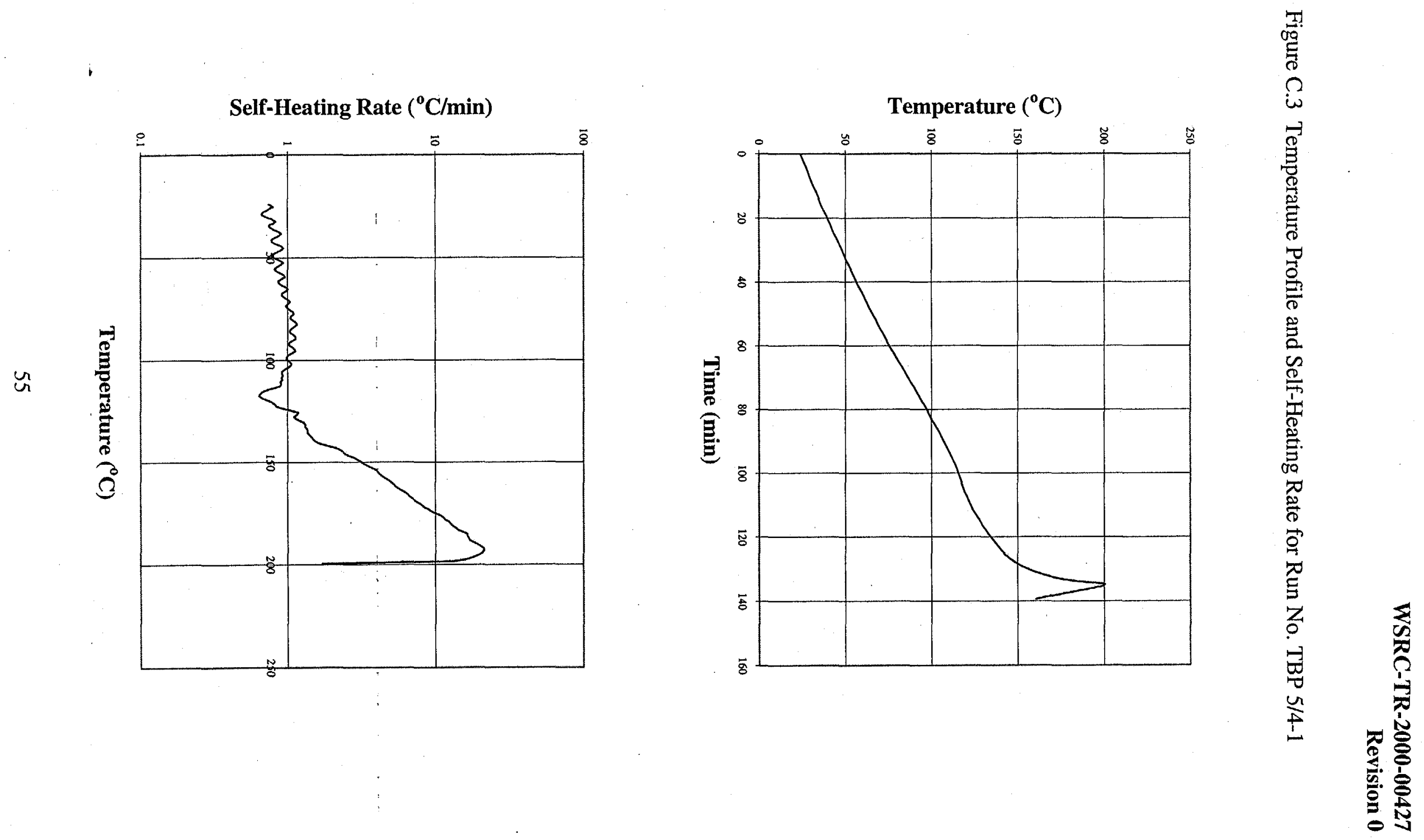
Figure C.4 Temperature Profile and Self-Heating Rate for Run No. TBP 0/15-1
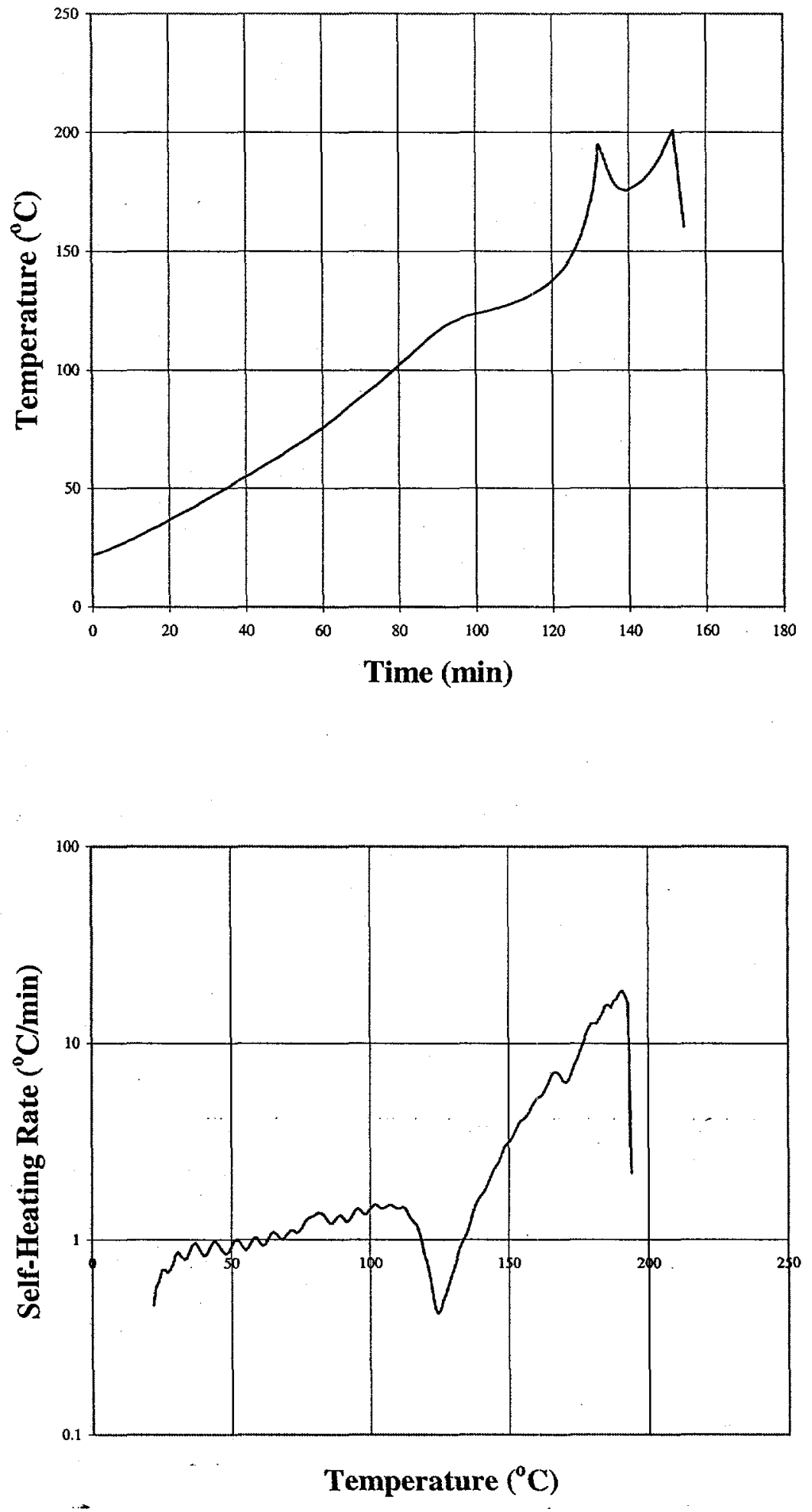

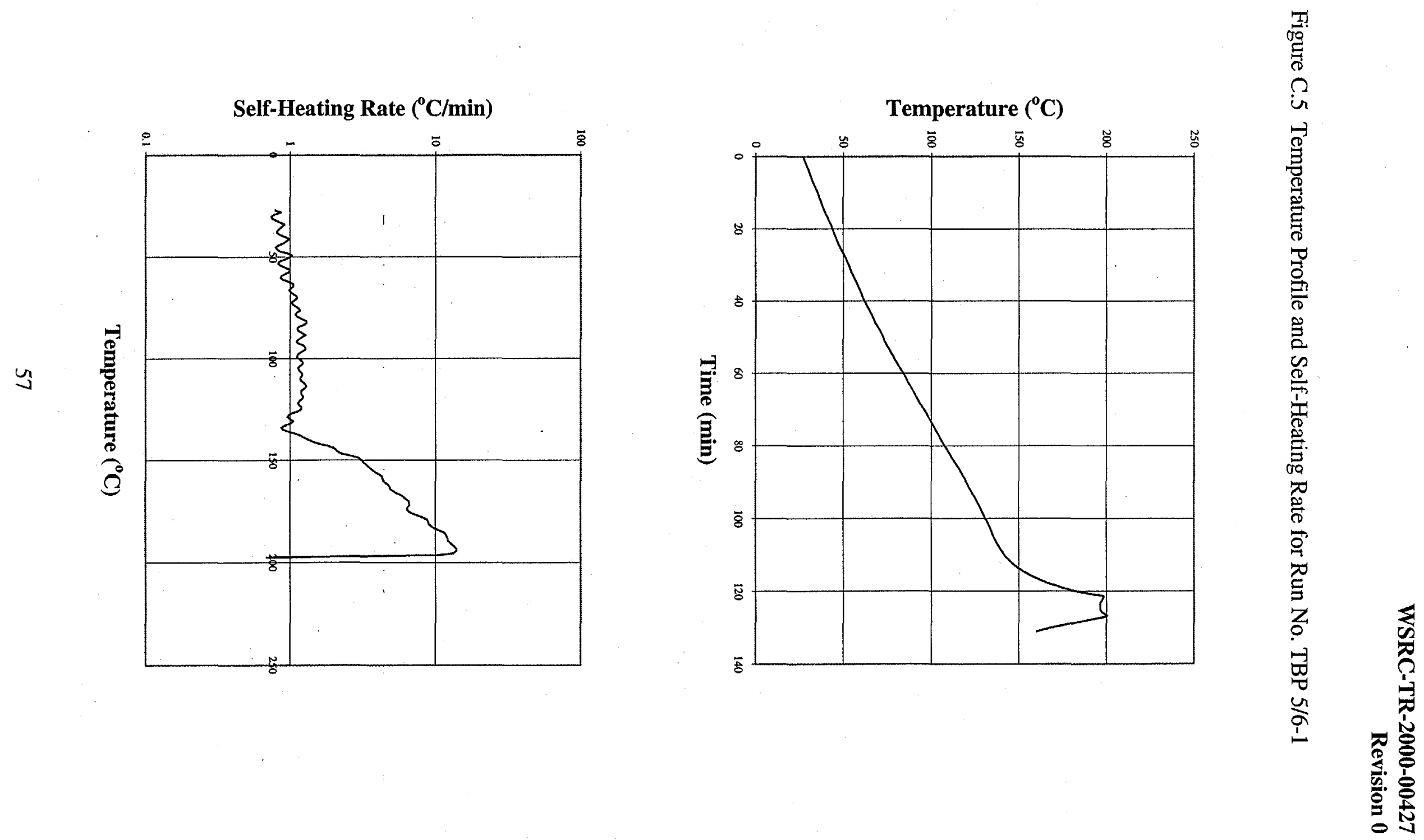
Figure C.6 Temperature Profile and Self-Heating Rate for Run No. TBP 5/4-2
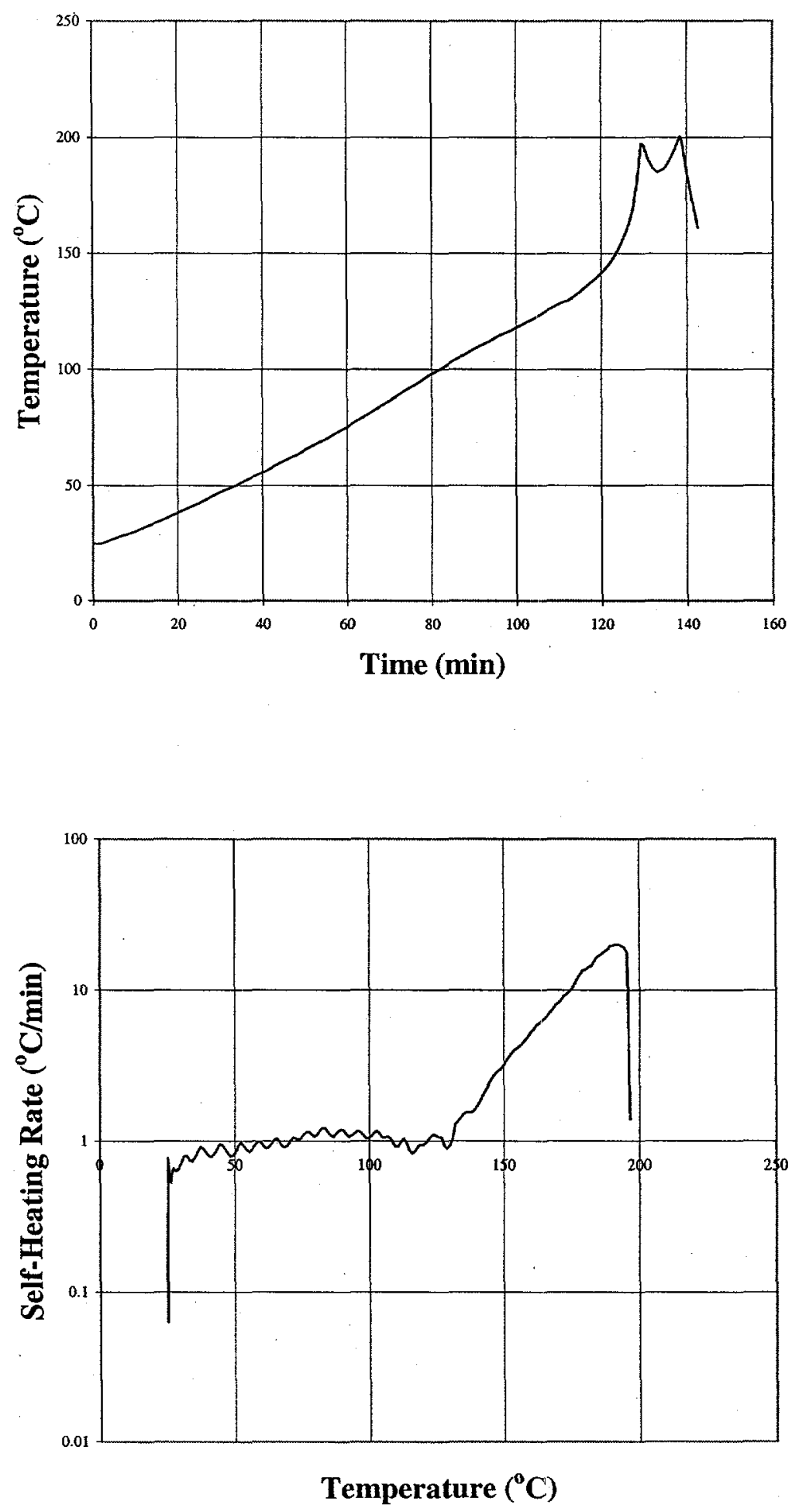
Figure C.7 Temperature Profile and Self-Heating Rate for Run No. TBP 0/8-1
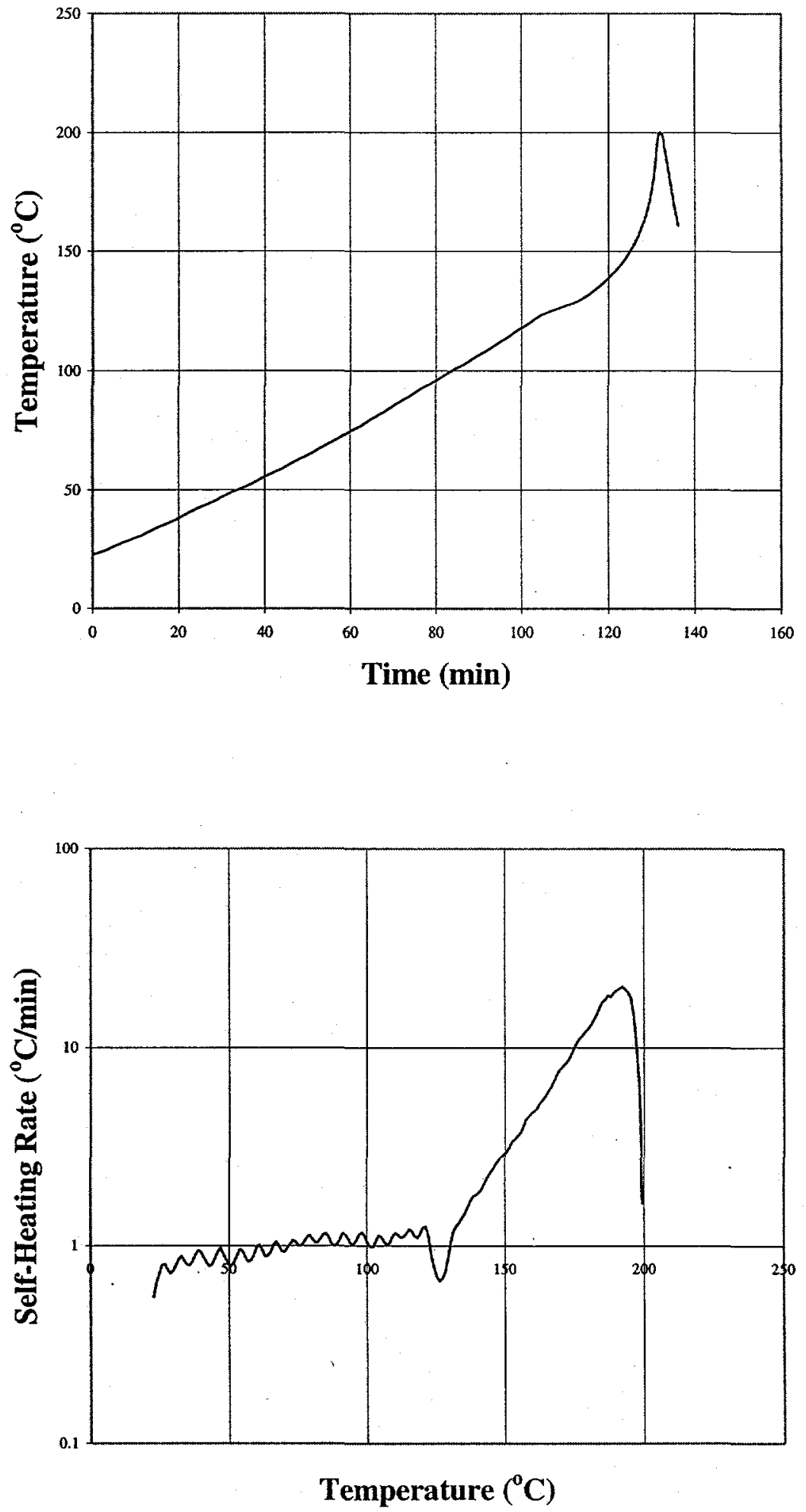
Figure C.8 Temperature Profile and Self-Heating Rate for Run No. TBP 0/2-1
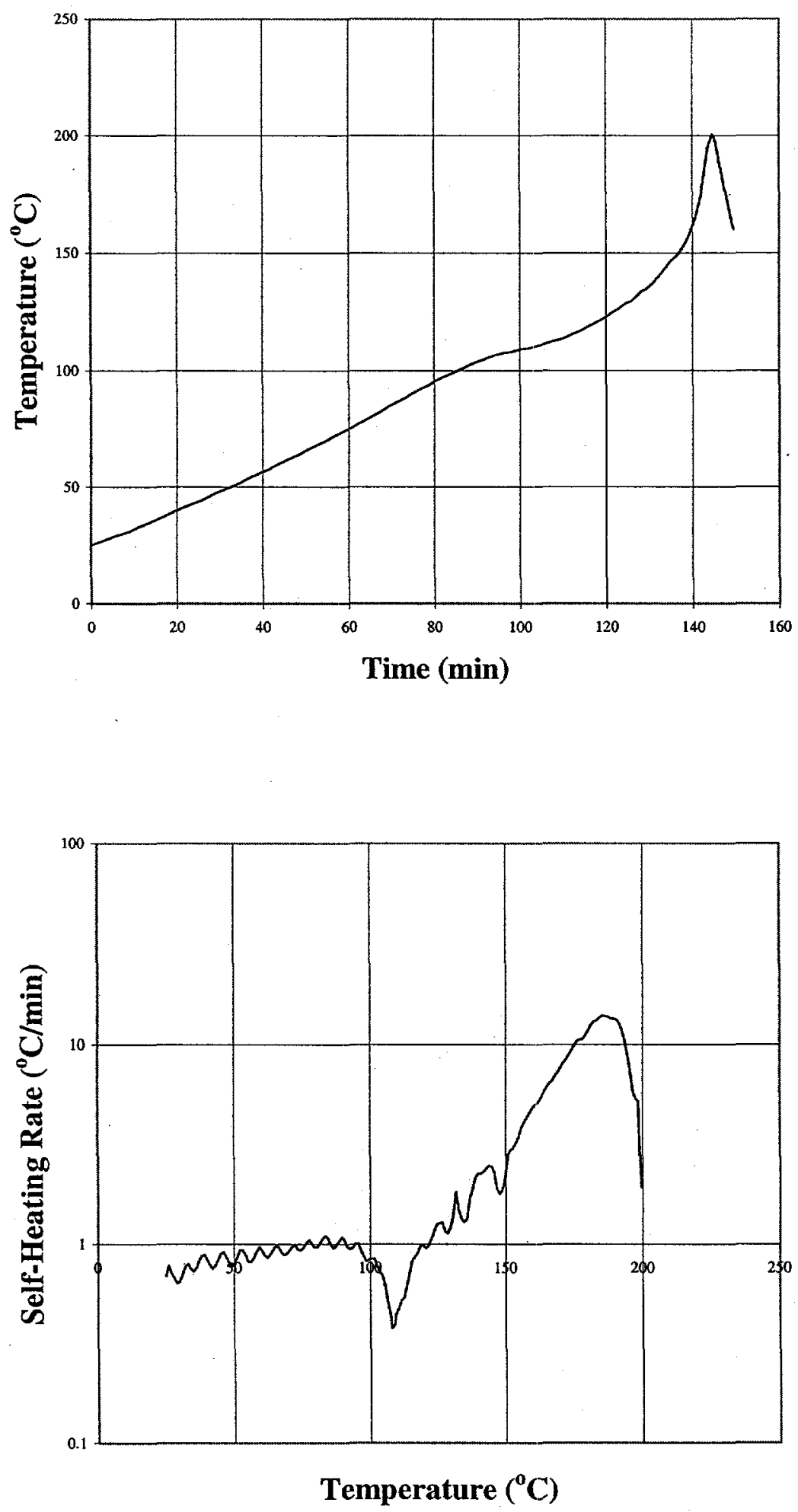
Figure C.9 Temperature Profile and Self-Heating Rate for Run No. TBP 5/4-3
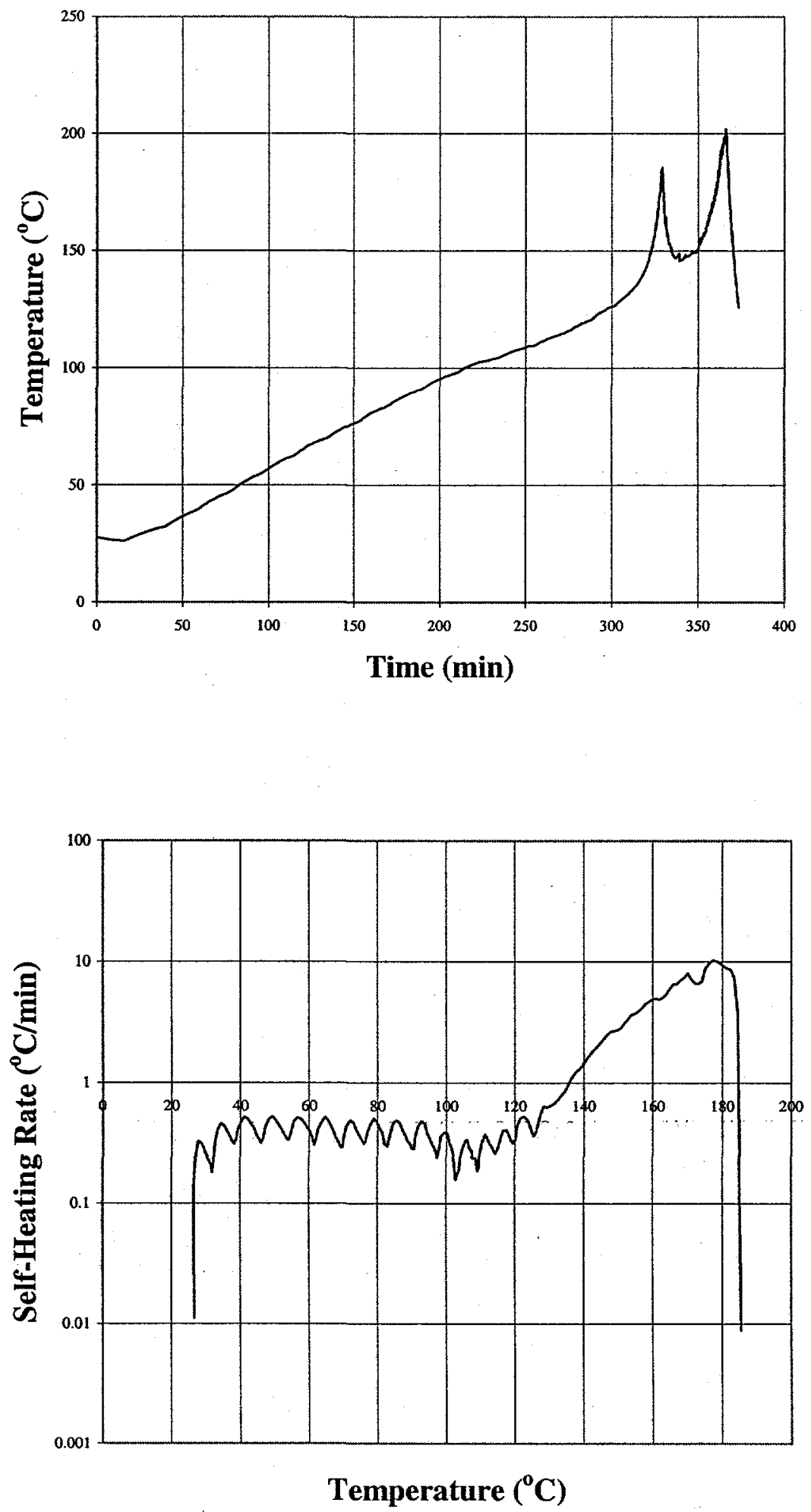
Figure C.10 Temperature Profile and Self-Heating Rate for Run No. TBP 5/4-4
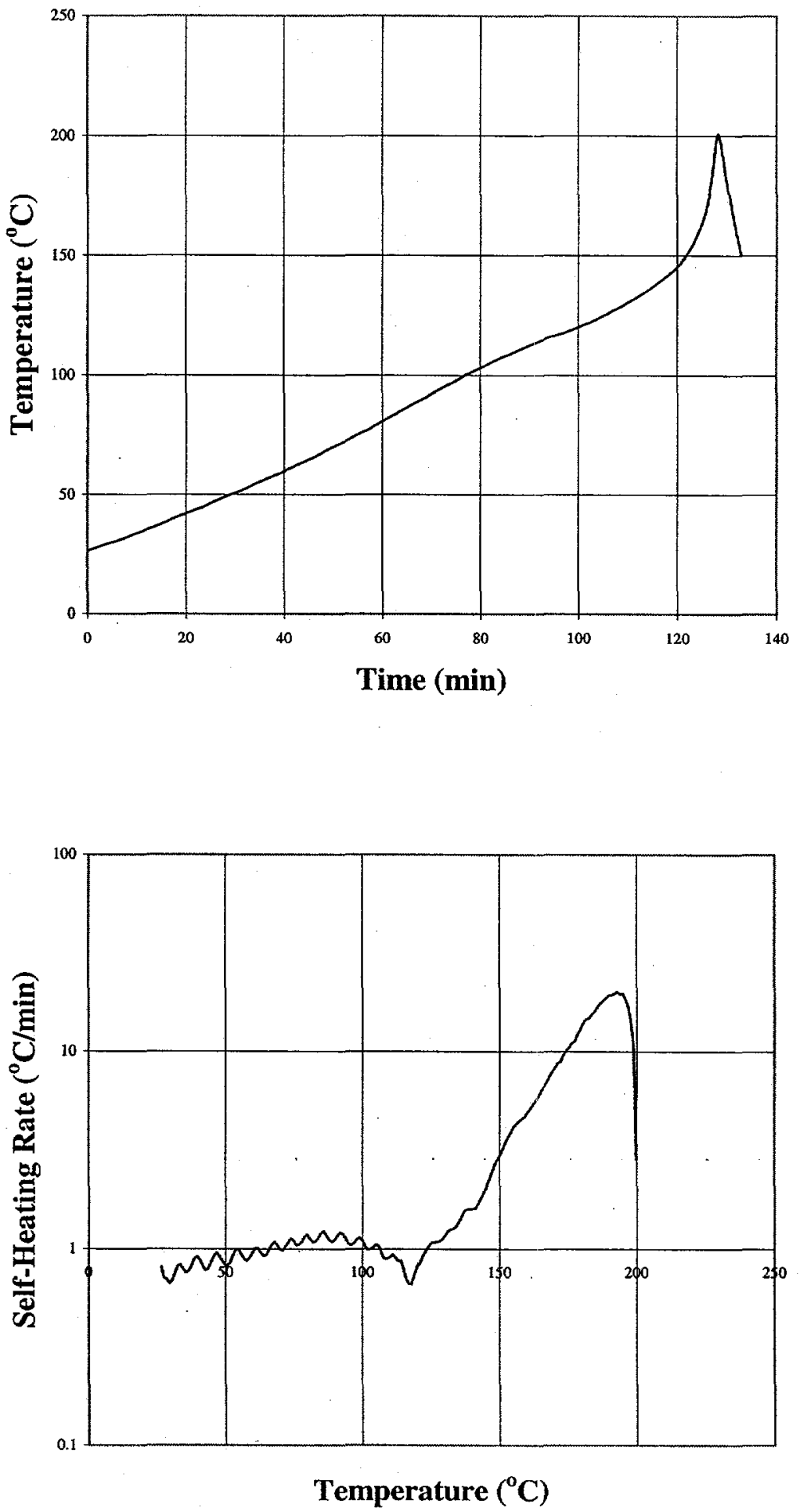
WSRC-TR-2000-00427

Revision 0

Appendix D Temperature and Pressure Profiles for Closed RSST ${ }^{\mathrm{TM}}$ Experiments 


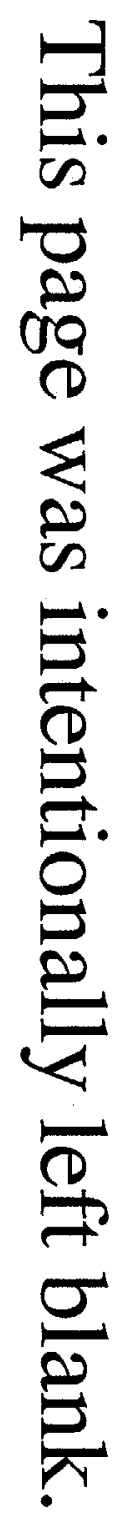


Figure D.1 Temperature and Pressure Profiles for Run No. TBP 0/0-1
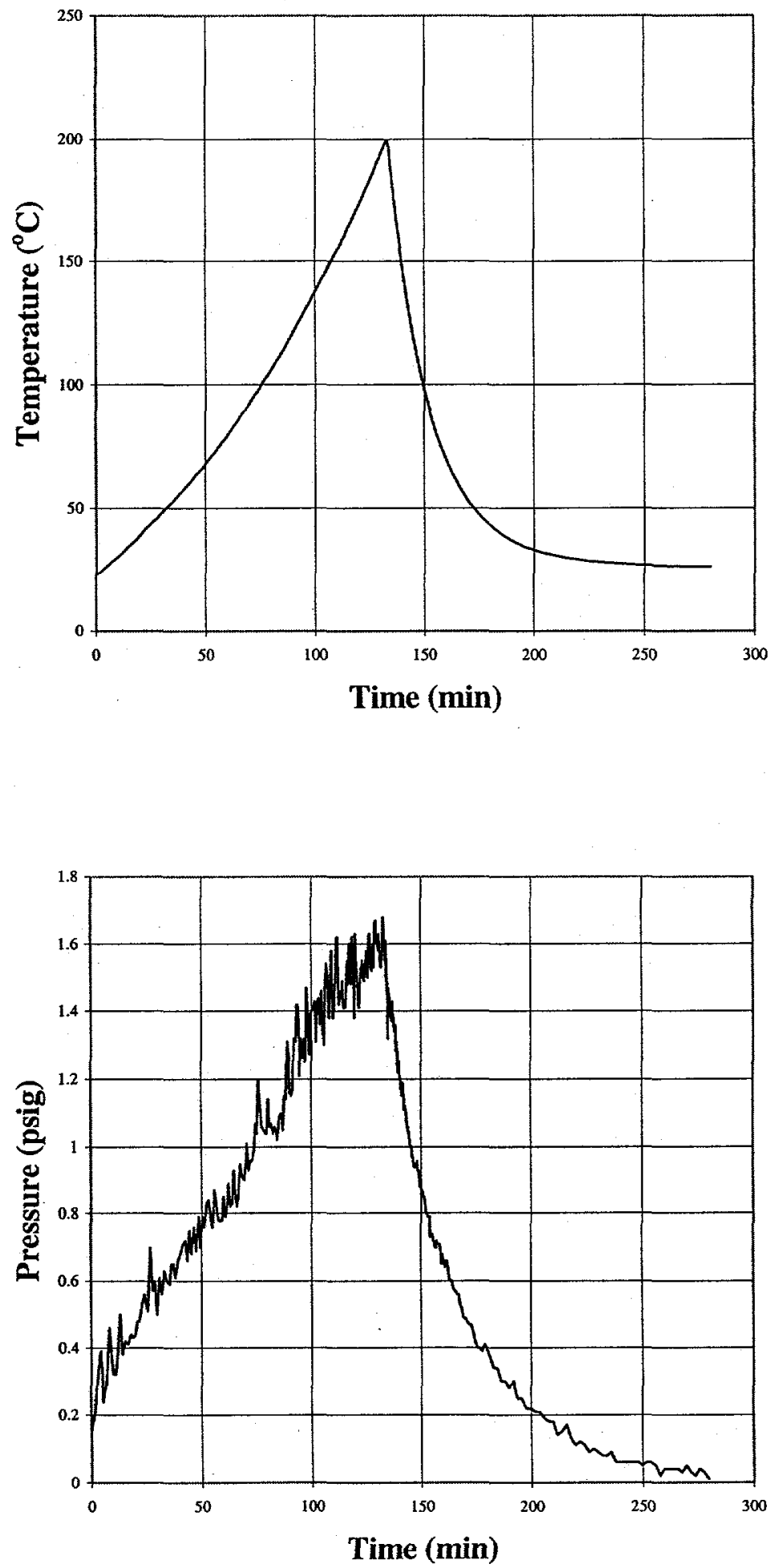
Figure D.2 Temperature and Pressure Profiles for Run No. TBP 0/4-3
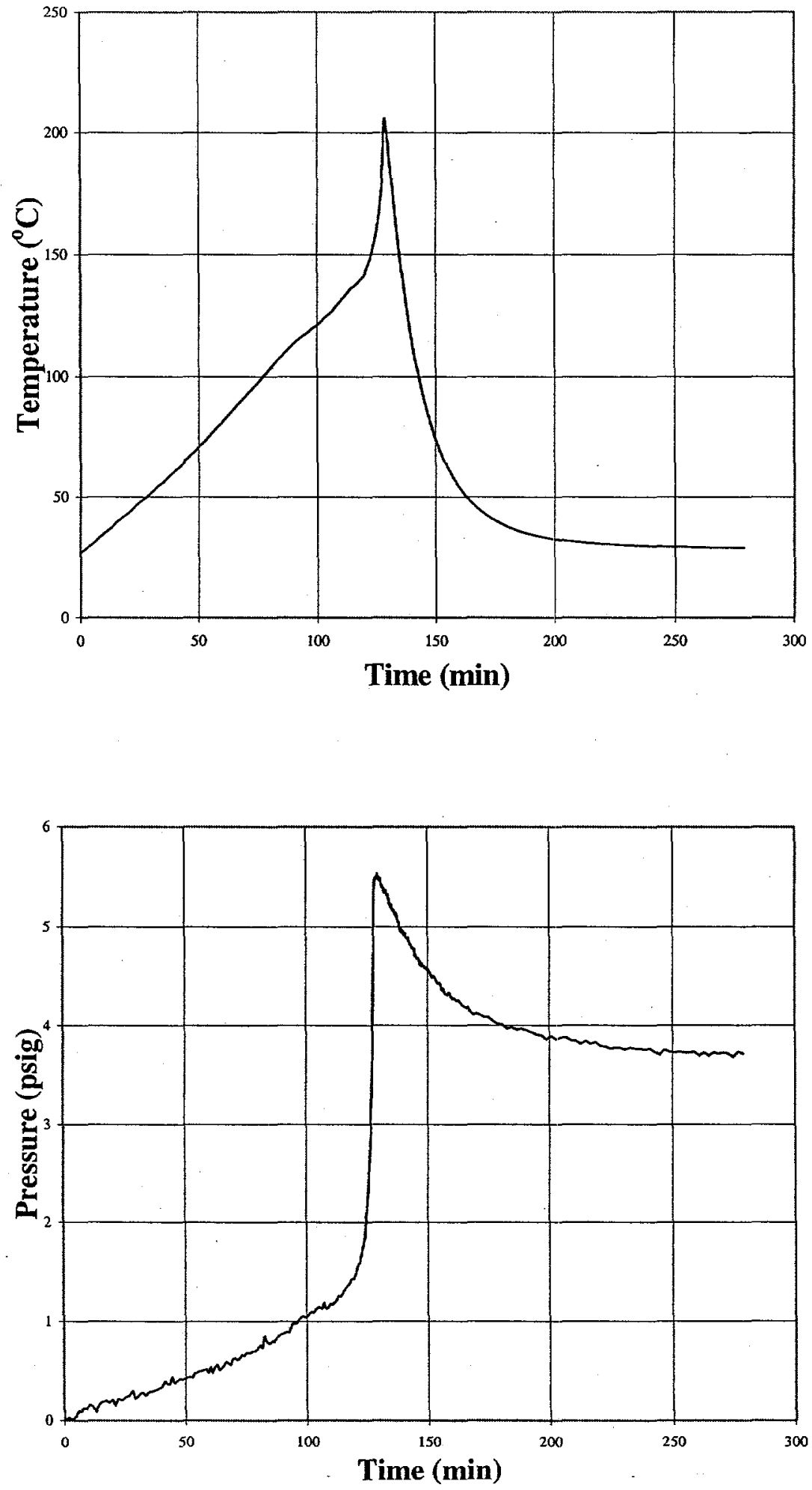
Figure D.3 Temperature and Pressure Profiles for Run No. TBP 0/8-2
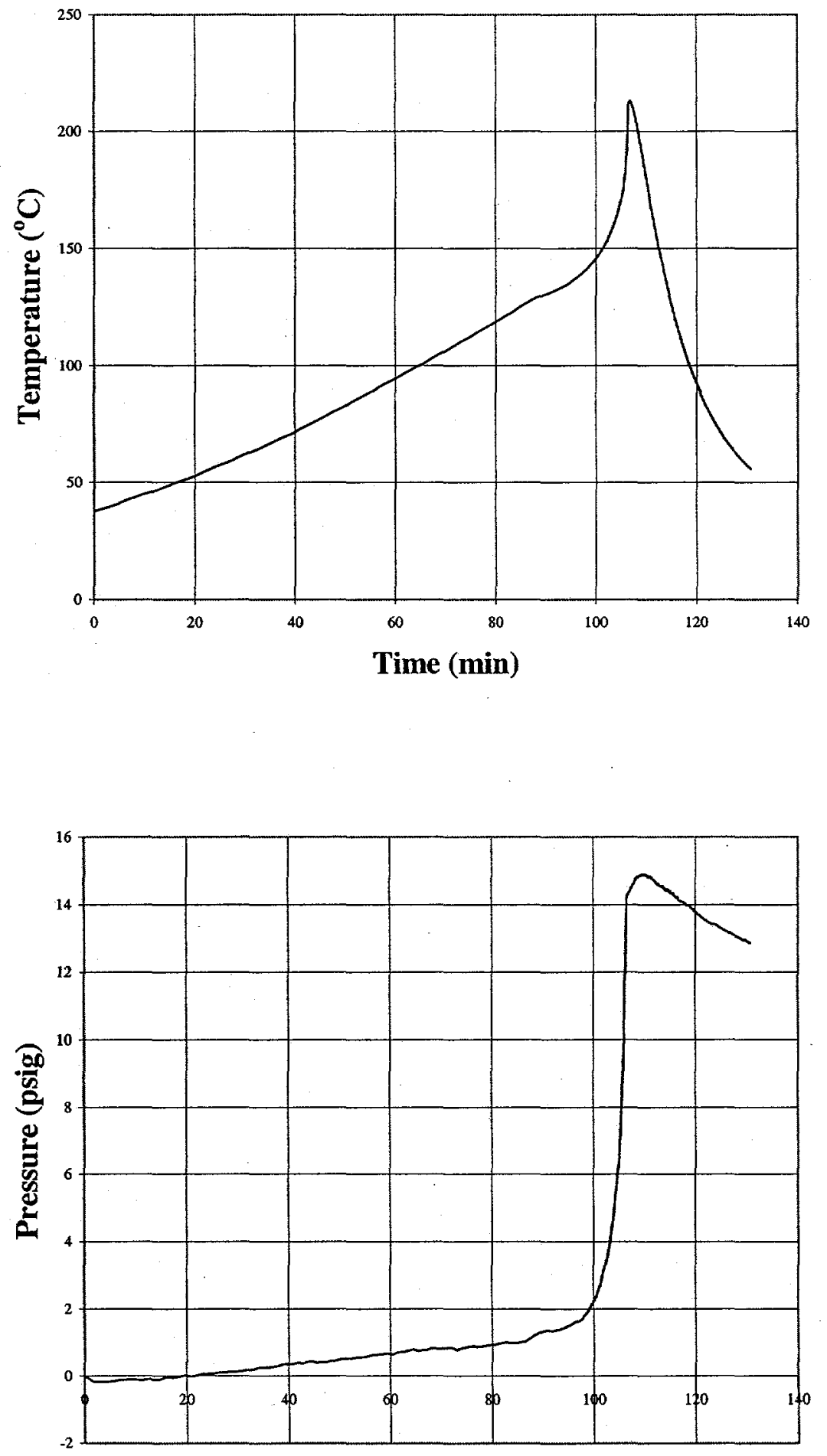

Time (min) 
Figure D.4 Temperature and Pressure Profiles for Run No. TBP 0/8-3
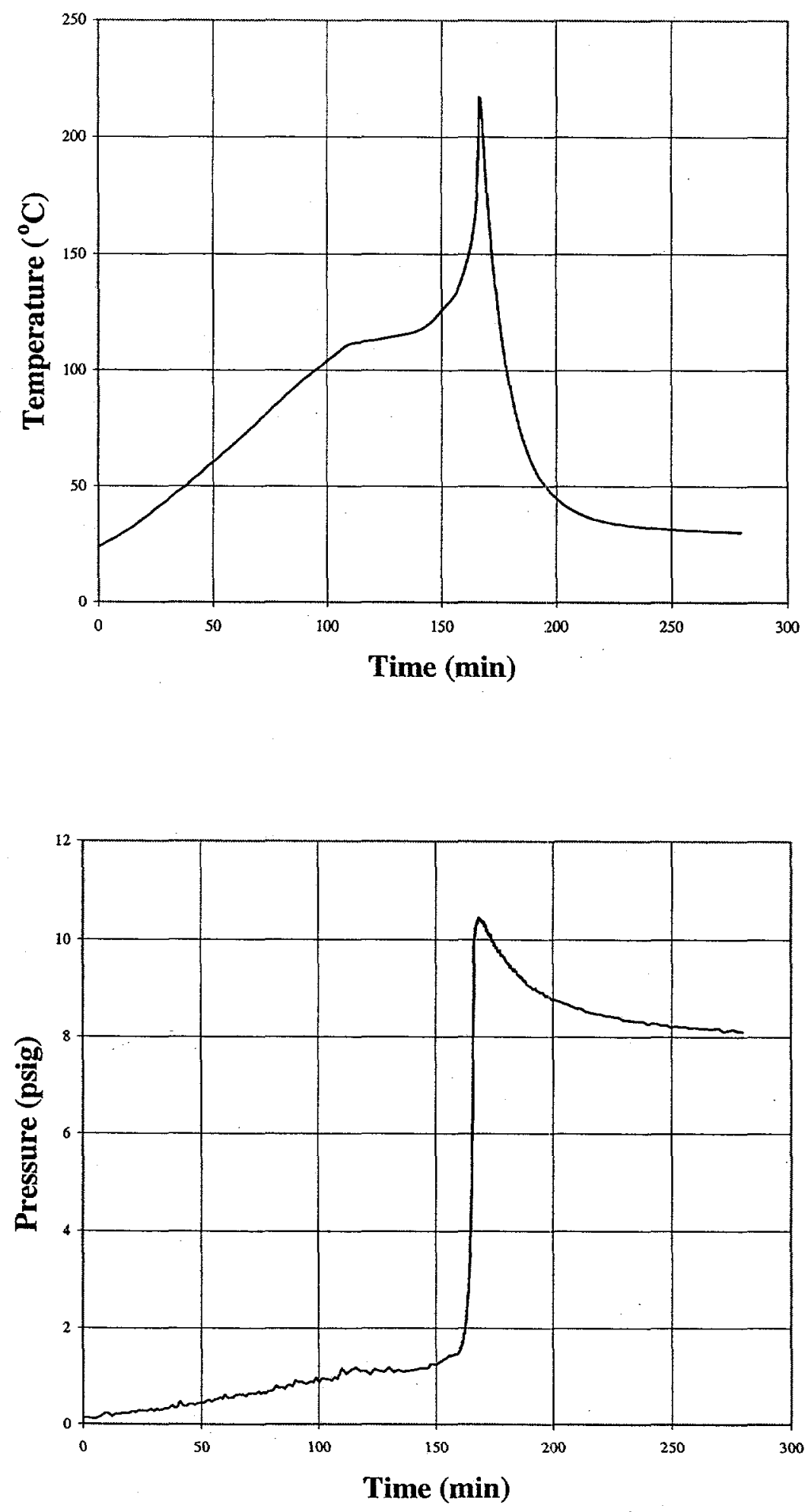

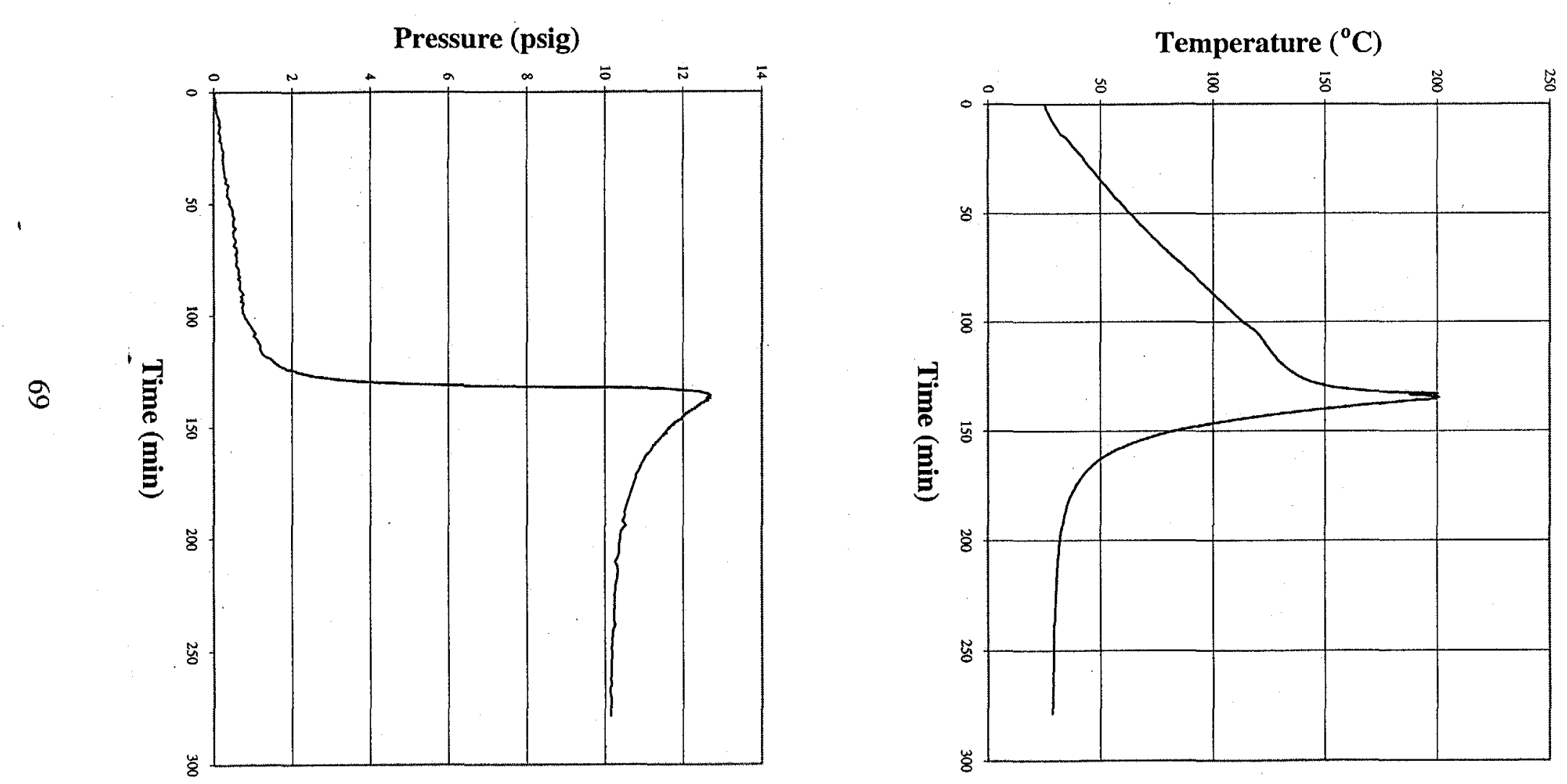

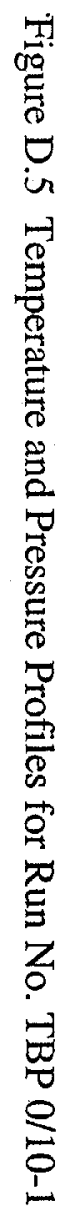


Figure D.6 Temperature and Pressure Profiles for Run No. TBP 0/12-1
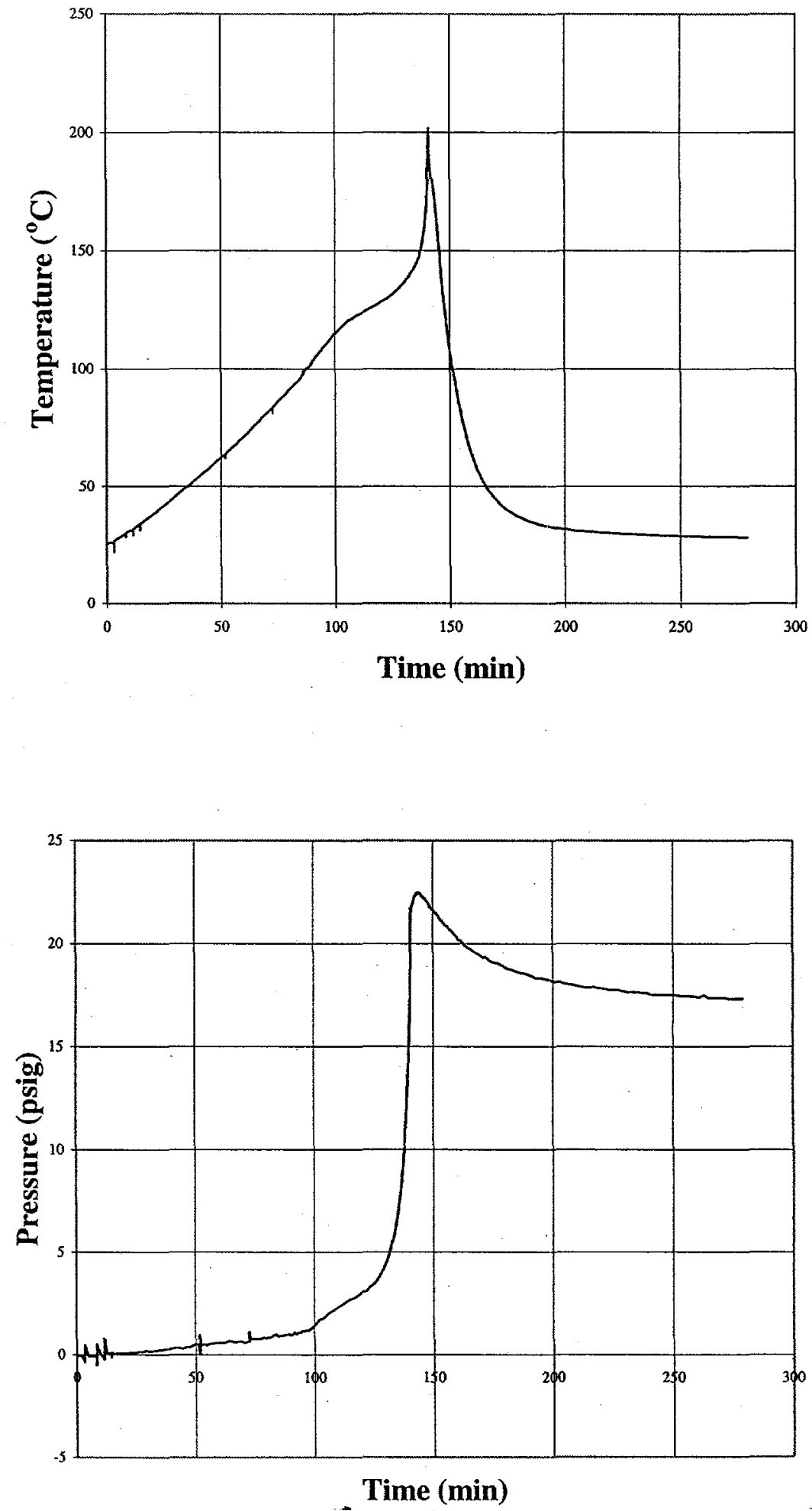

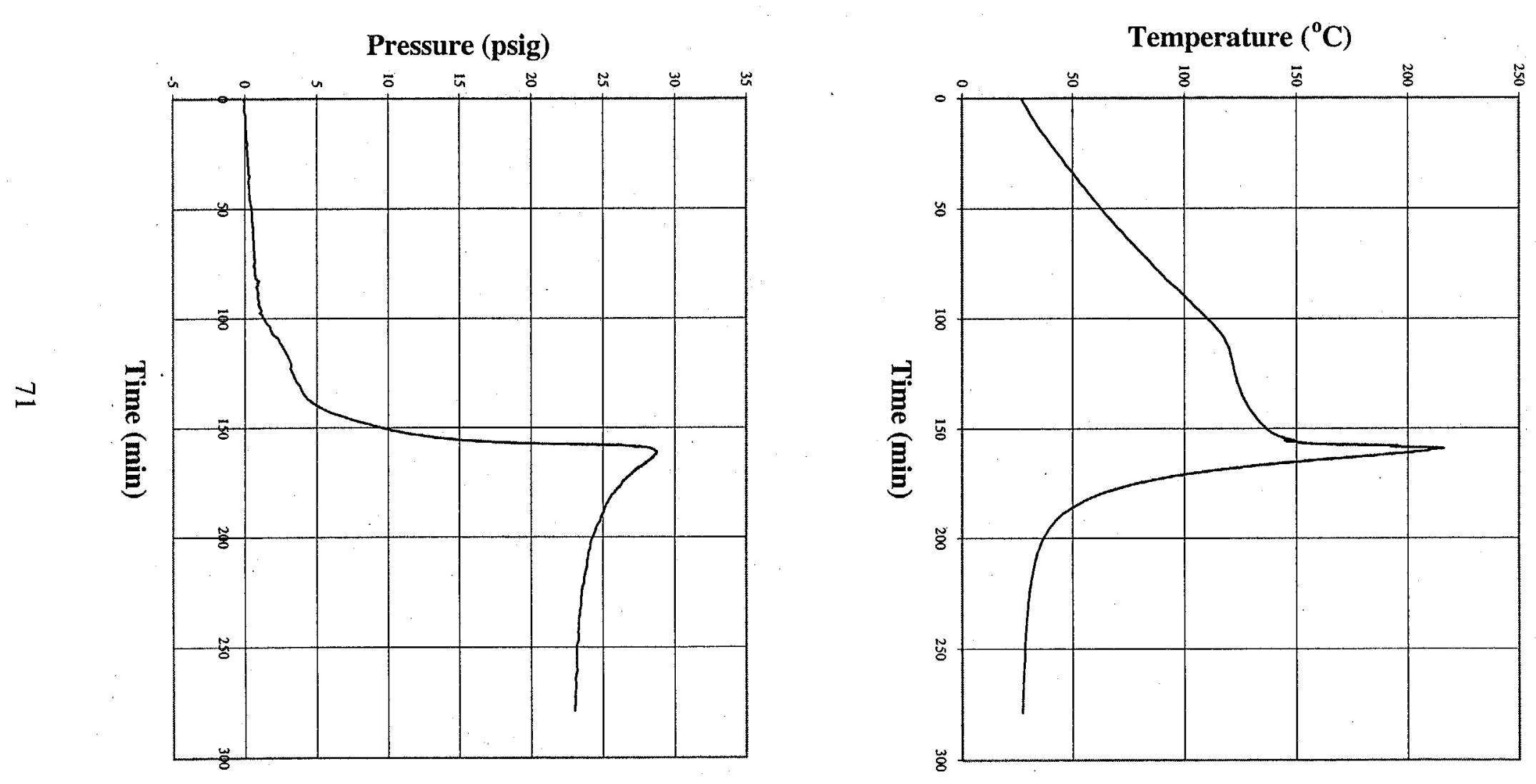

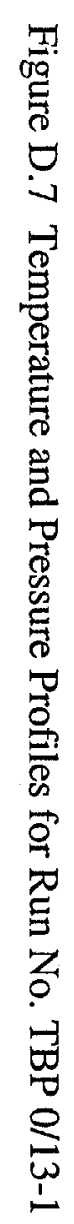

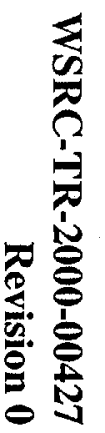


Figure D.8 Temperature and Pressure Profiles for Run No. TBP 0/14-1
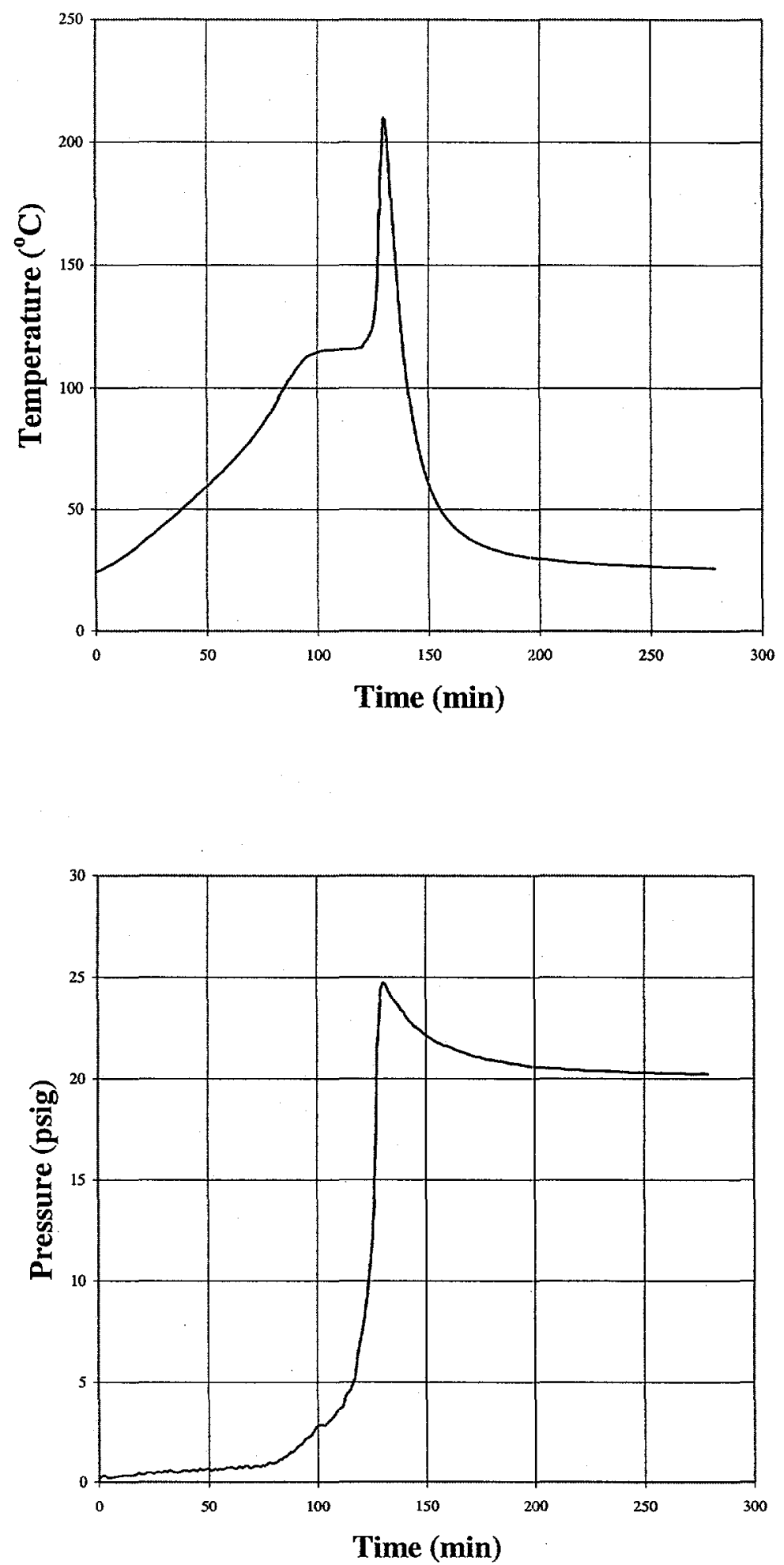
Figure D.9 Temperature and Pressure Profiles for Run No. TBP 0/15-2
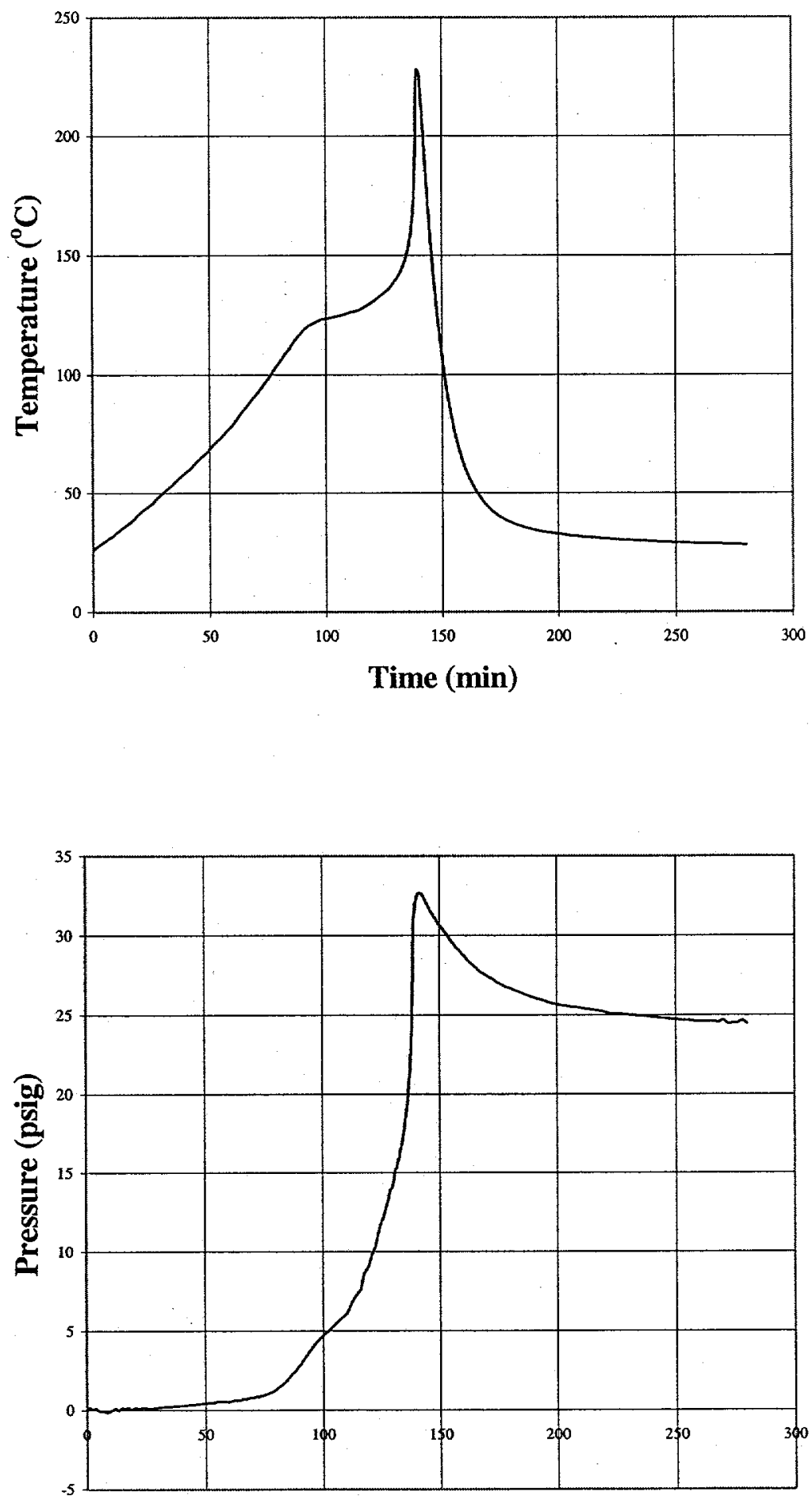

Time (min) 
Figure D.10 Temperature and Pressure Profiles for Run No. TBP 0/15-3
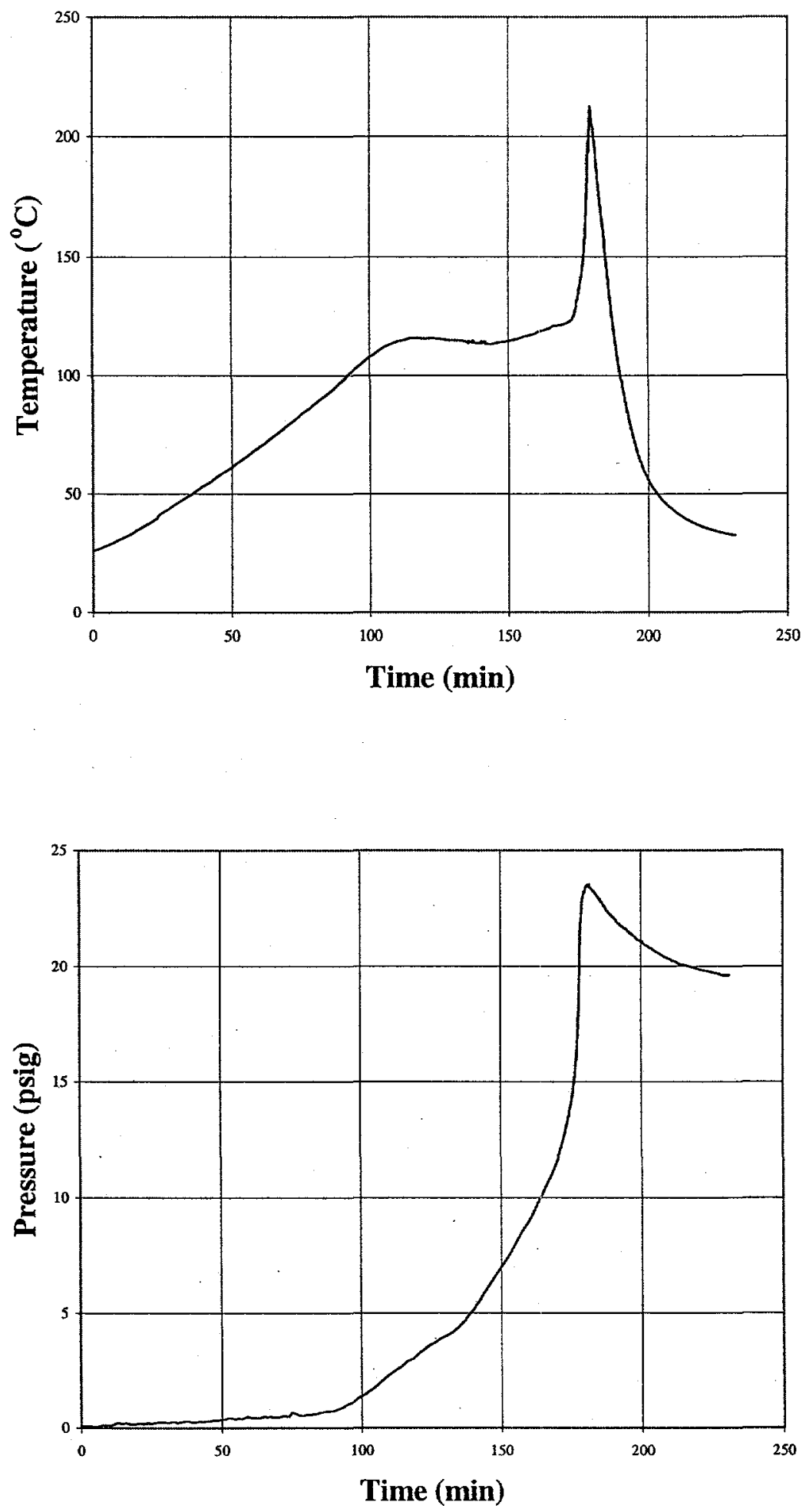
Figure D.11 Temperature and Pressure Profiles for Run No. TBP 5/4-7
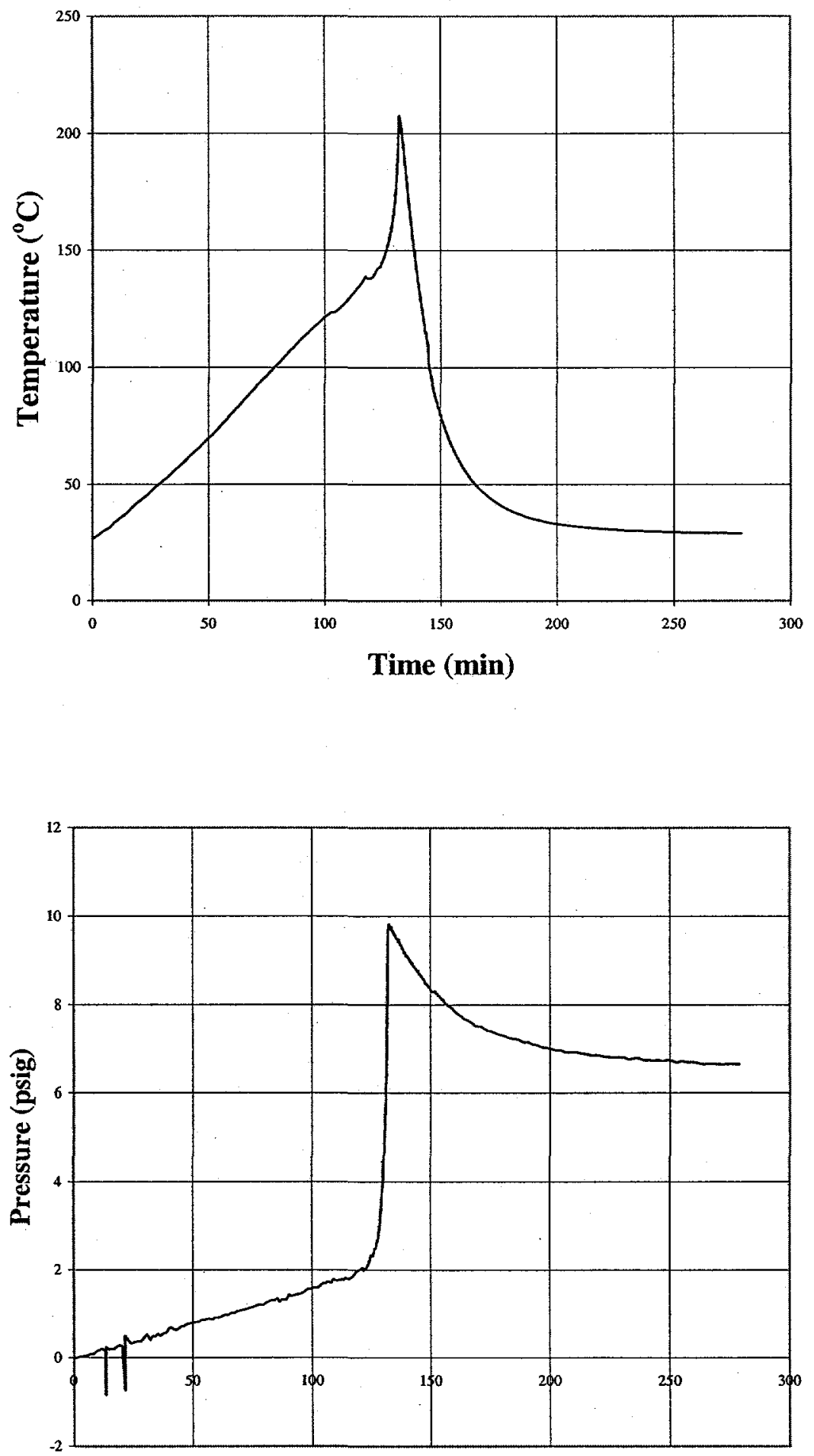

Time (min) 
Figure D.12 Temperature and Pressure Profiles for Run No. TBP 5/4-8
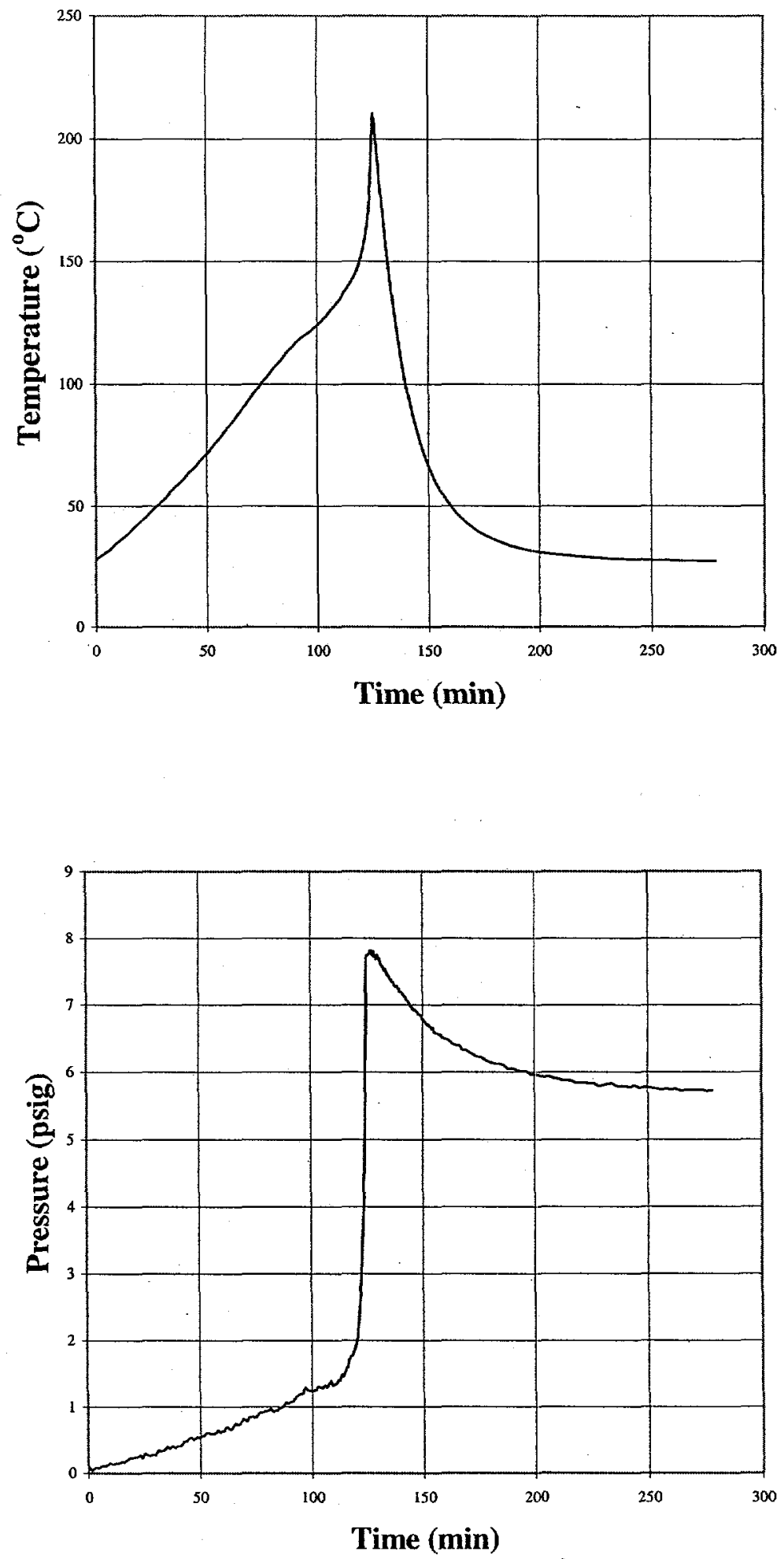
Figure D.13 Temperature and Pressure Profiles for Run No. TBP 5/6-2
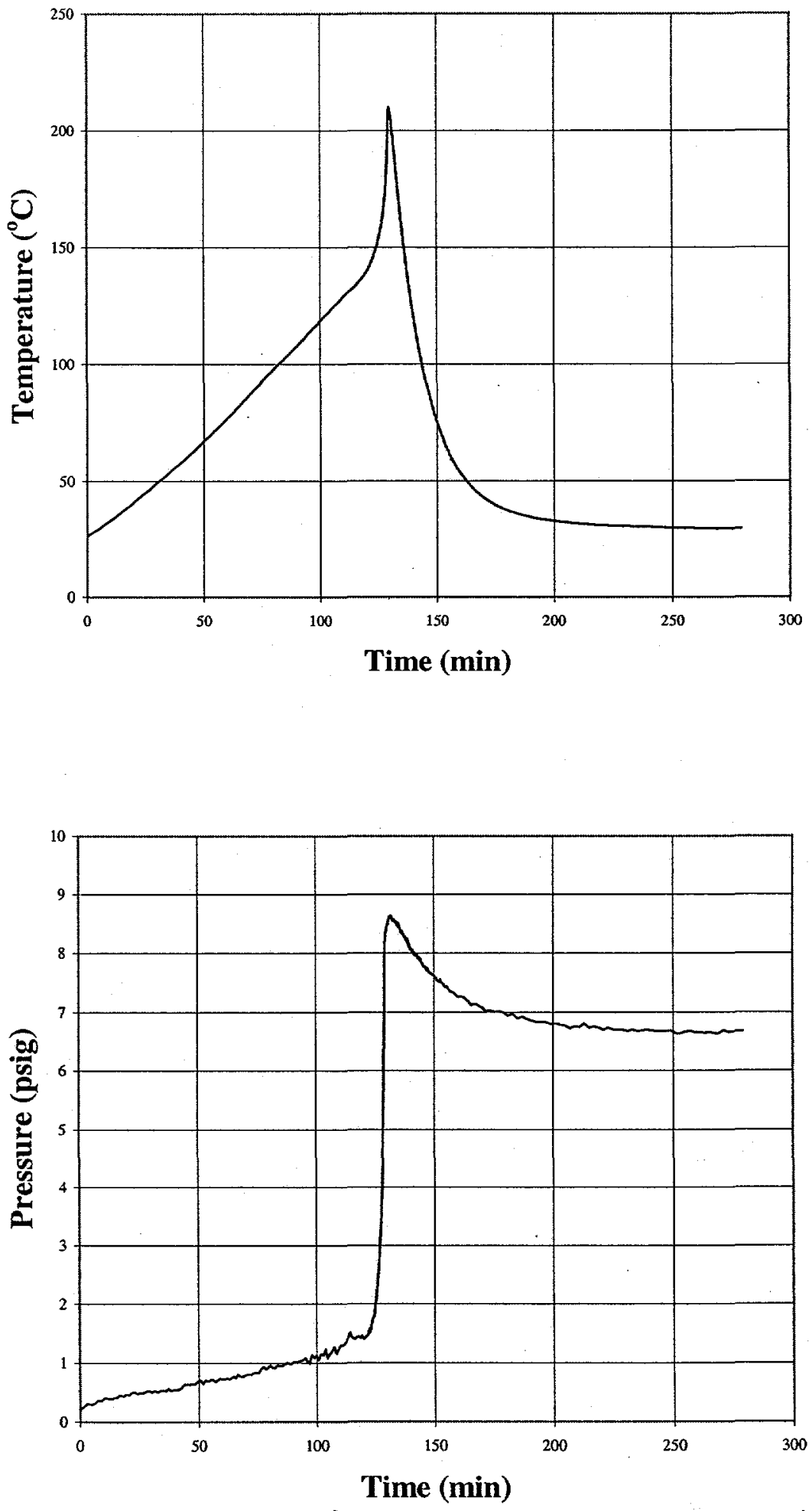
Figure D.14 Temperature and Pressure Profiles for Run No. TBP 5/8-1
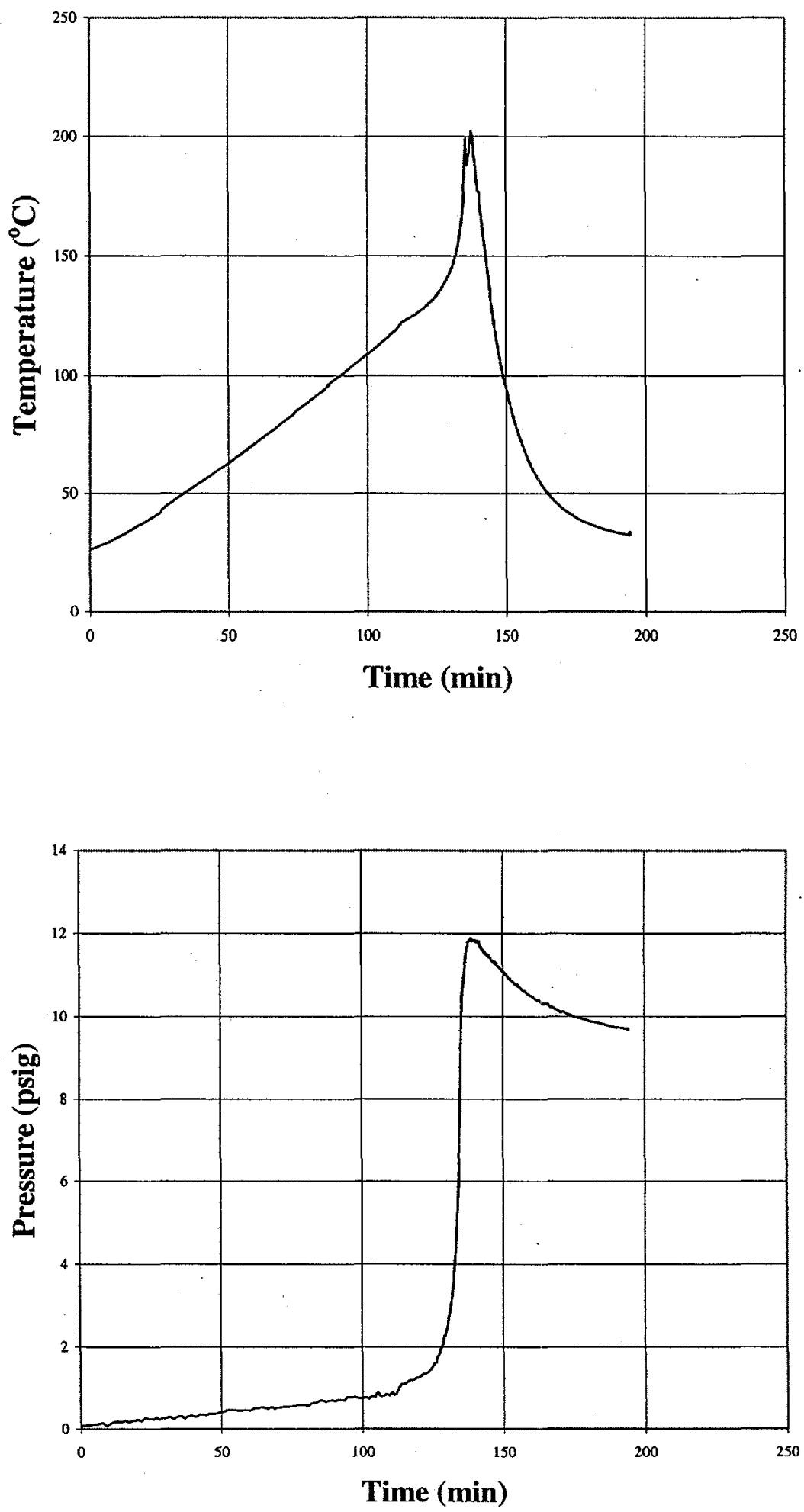
Figure D.15 Temperature and Pressure Profiles for Run No. TBP 5/8-2
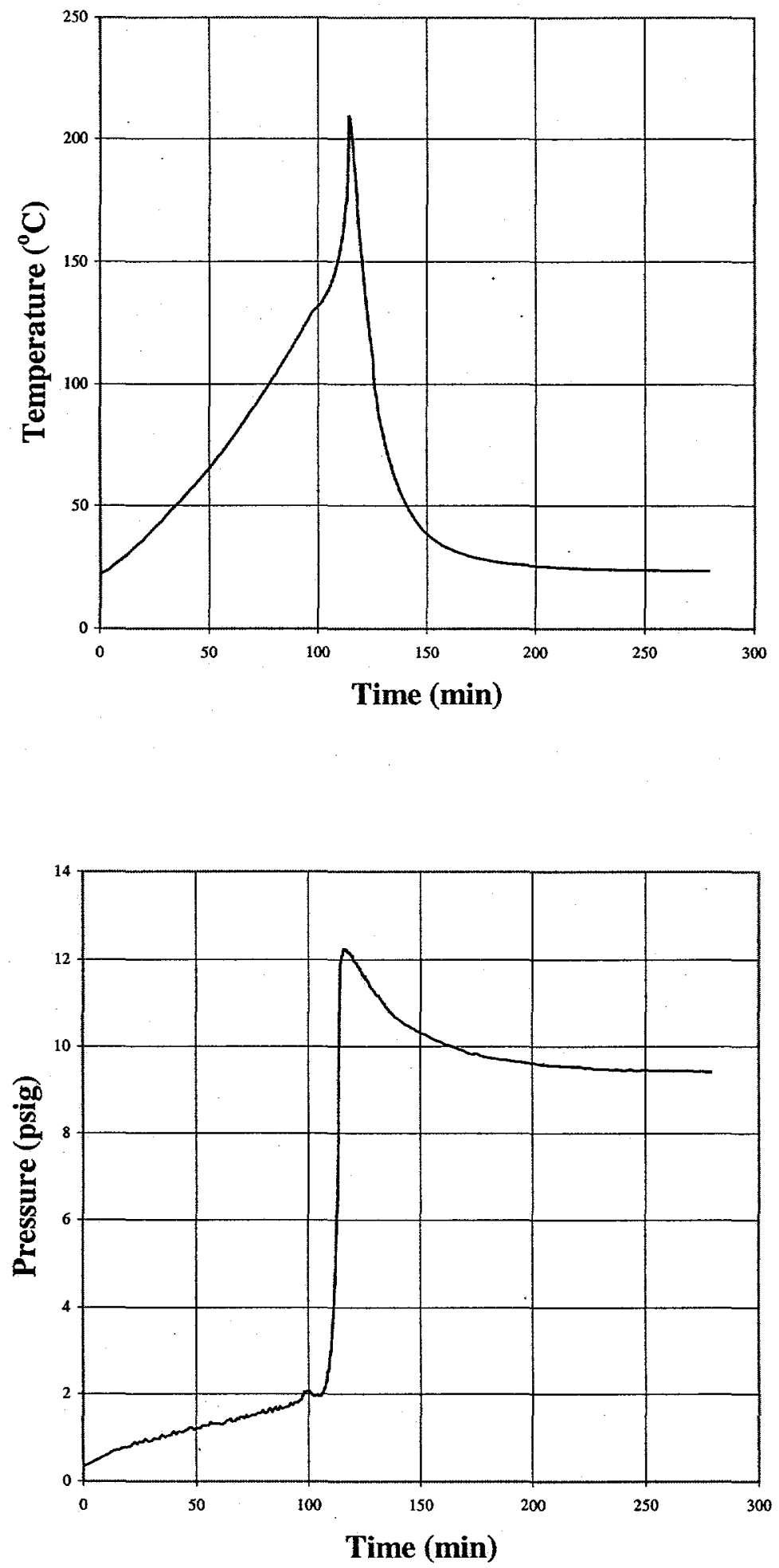
Figure D.16 Temperature and Pressure Profiles for Run No. TBP 5/10-1
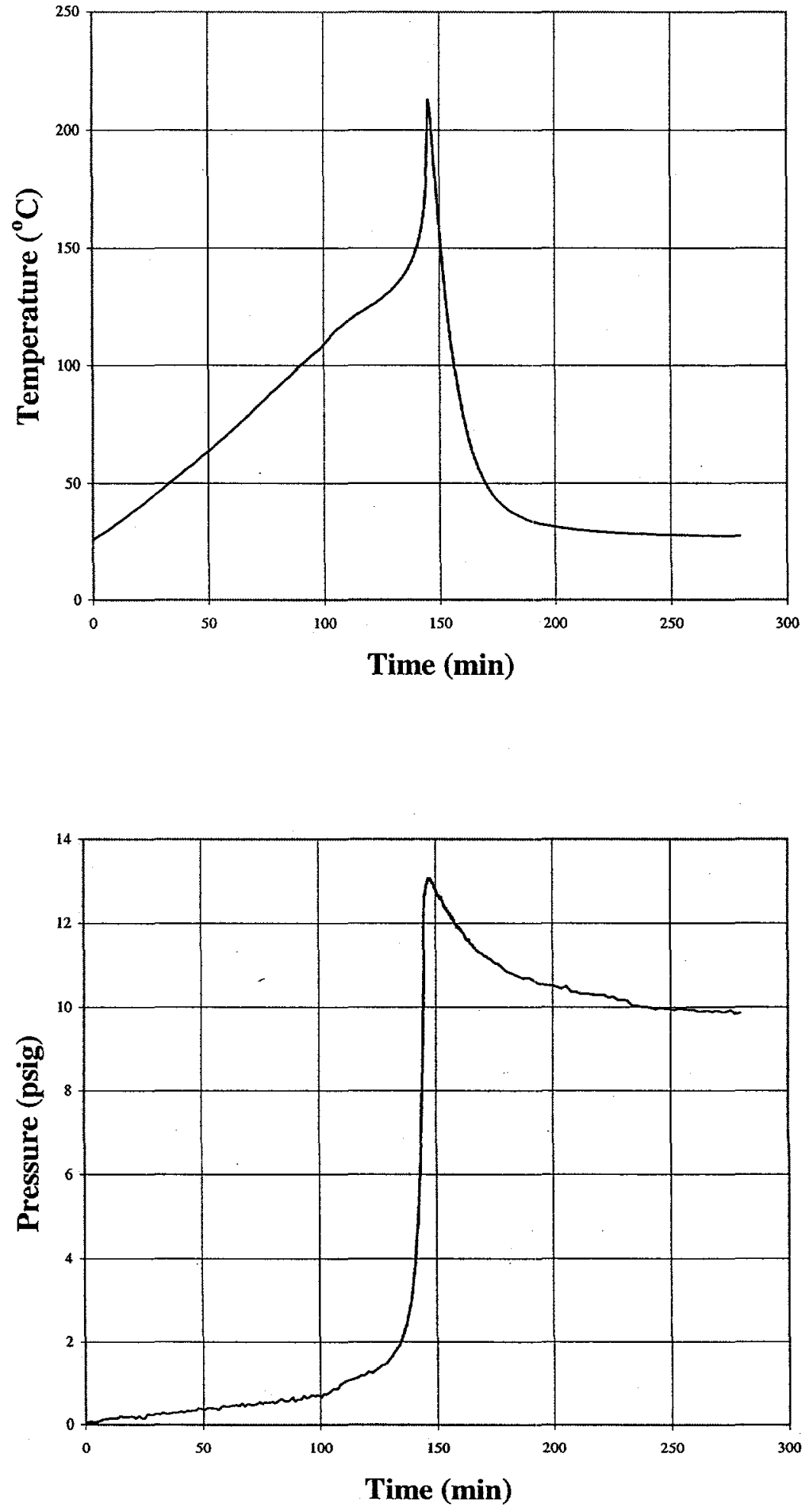
Figure D.17 Temperature and Pressure Profiles for Run No. TBP 5/12-3
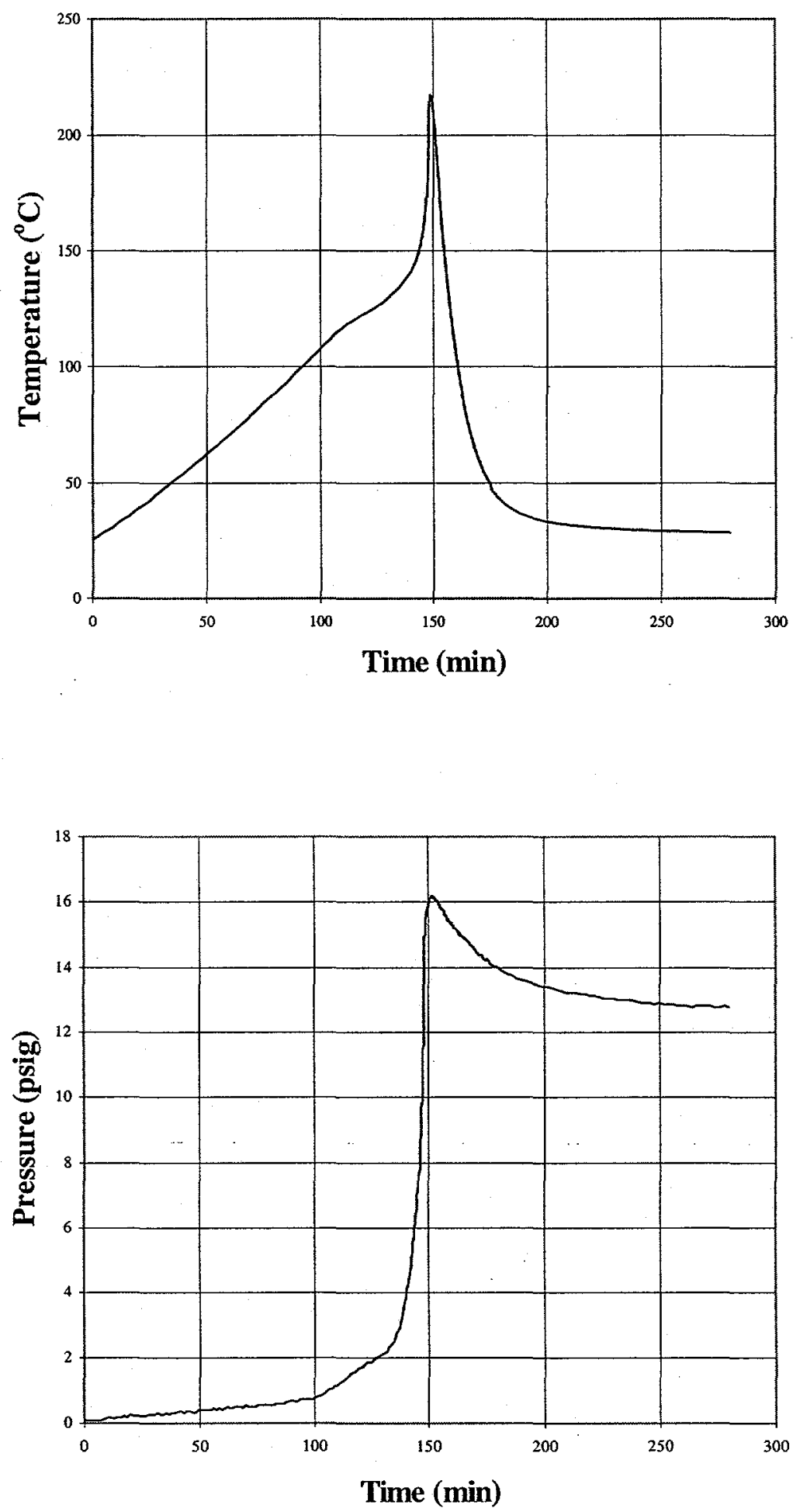
Figure D.18 Temperature and Pressure Profiles for Run No. TBP 5/12-4
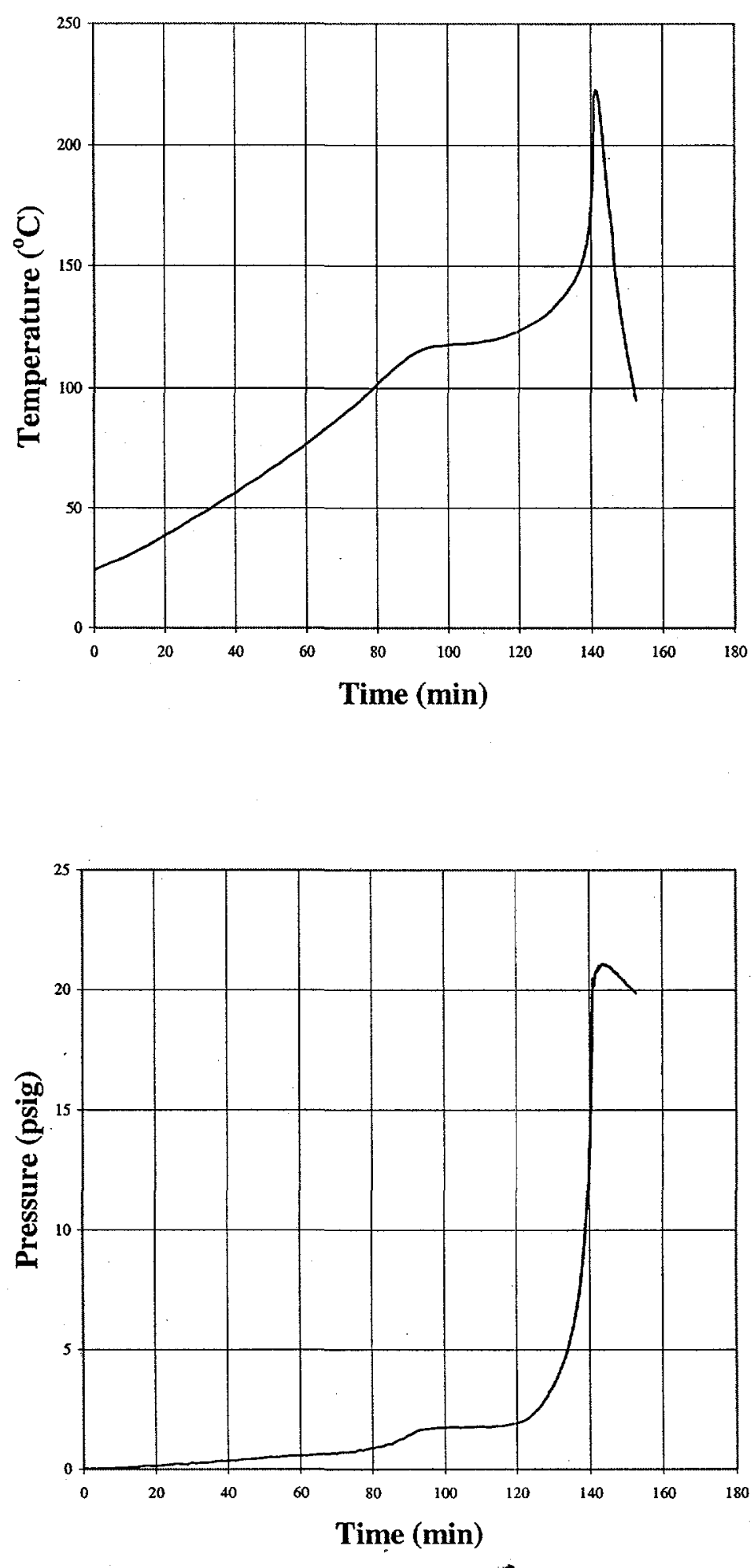
Figure D.19 Temperature and Pressure Profiles for Run No. TBP 10/4-1
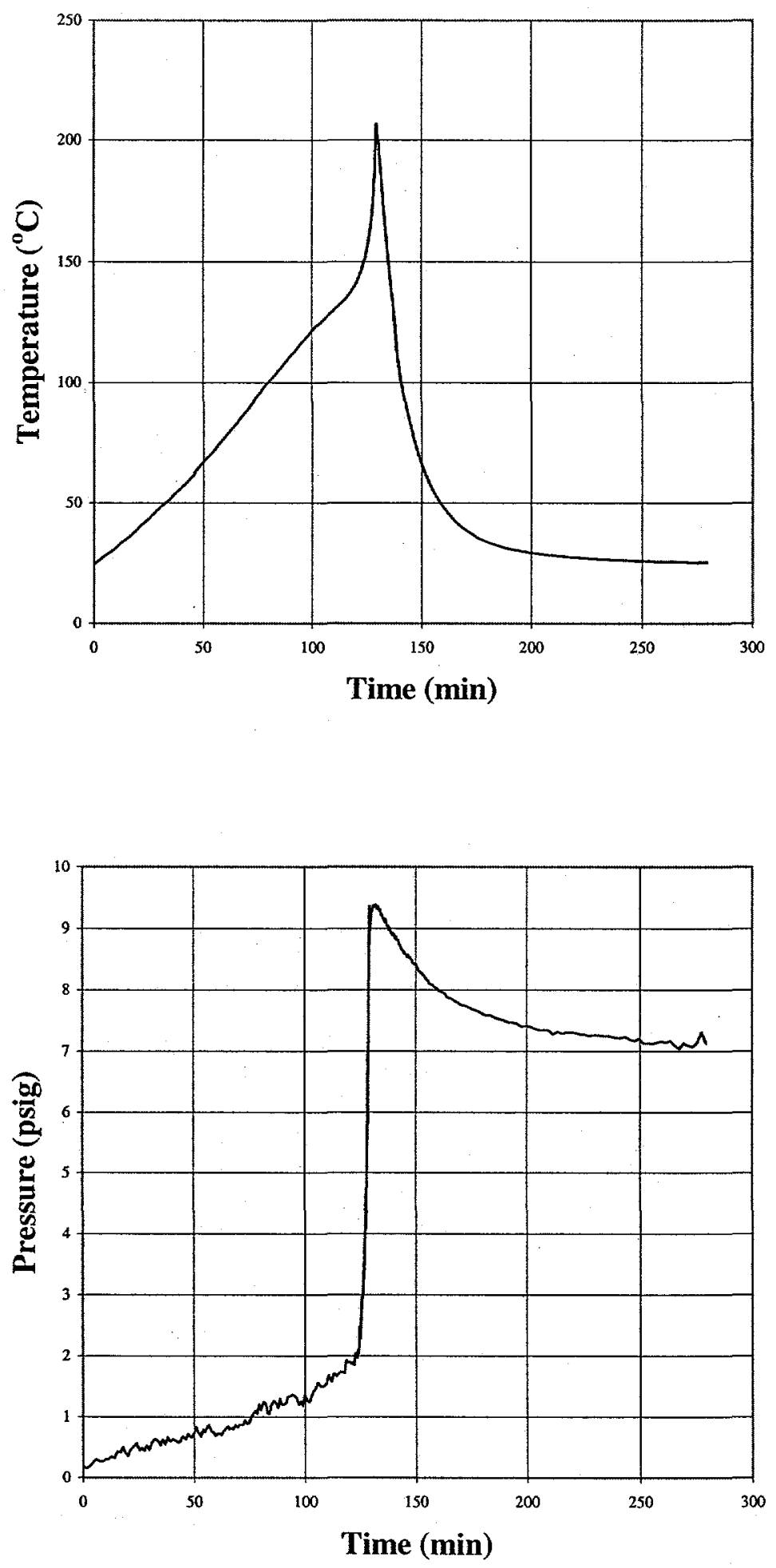
Figure D.20 Temperature and Pressure Profiles for Run No. TBP 10/4-2
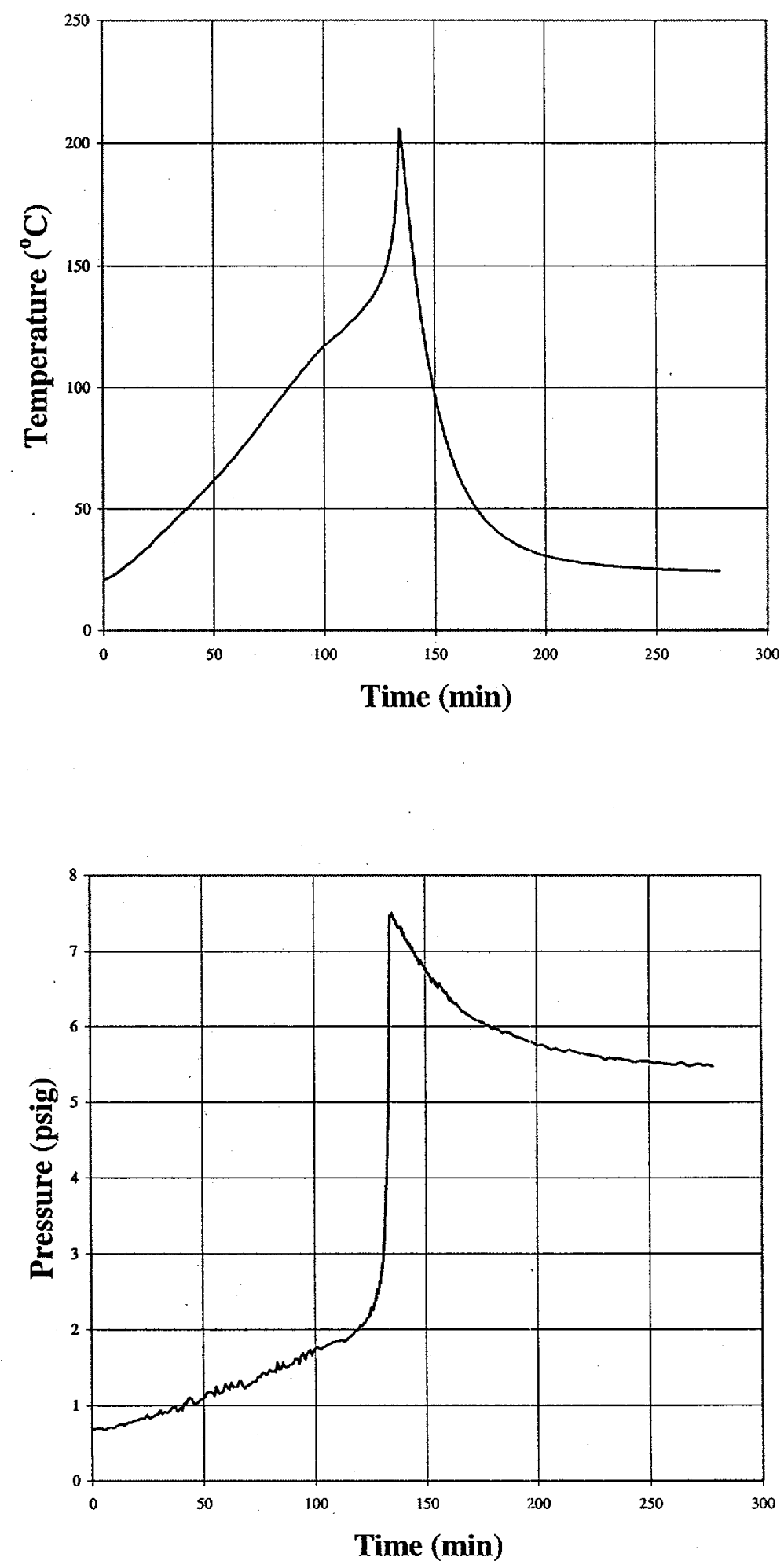
Figure D.22 Temperature and Pressure Profiles for Run No. TBP 10/8-1
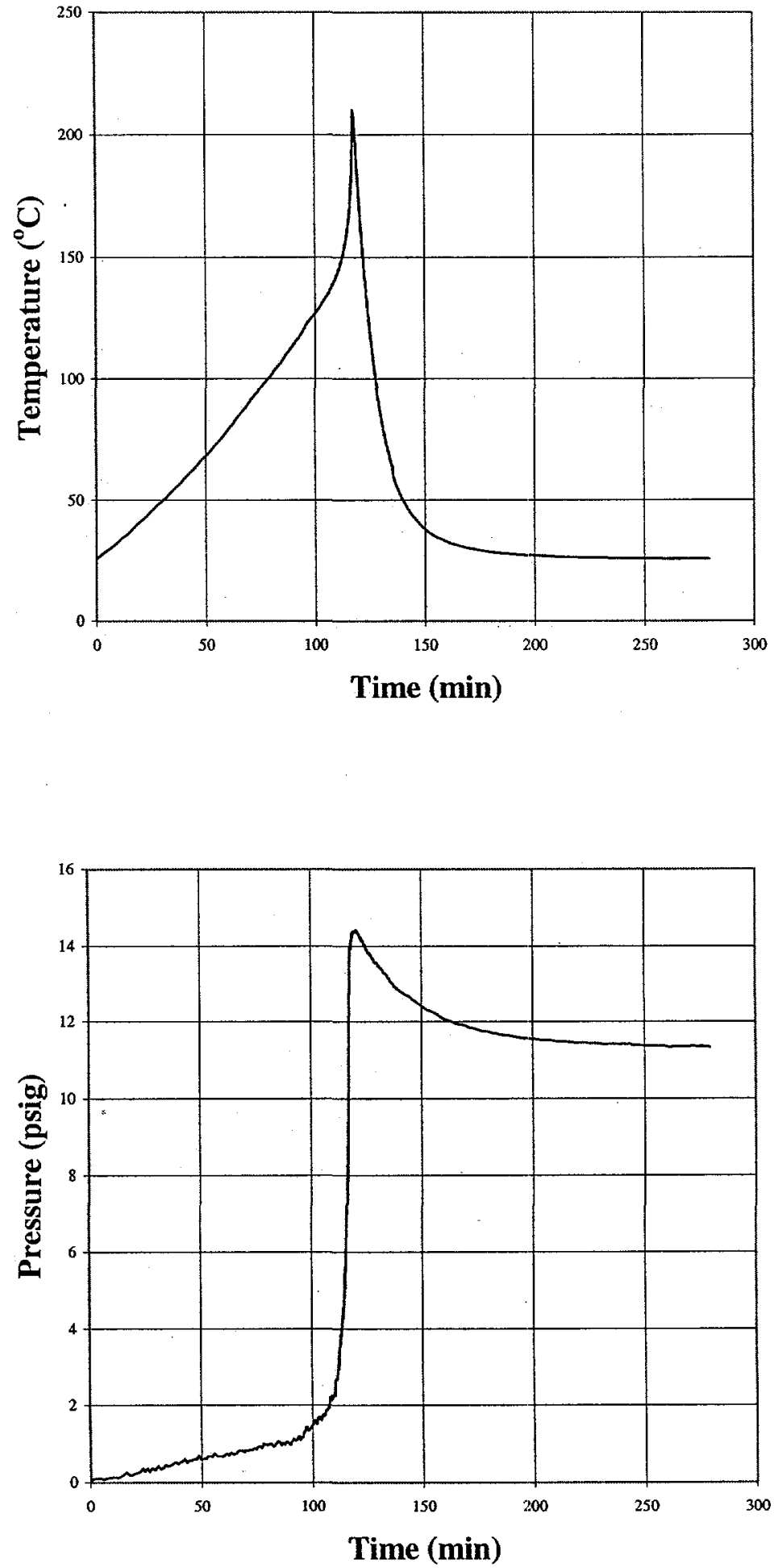
Figure D.23 Temperature and Pressure Profiles for Run No. TBP 10/8-2
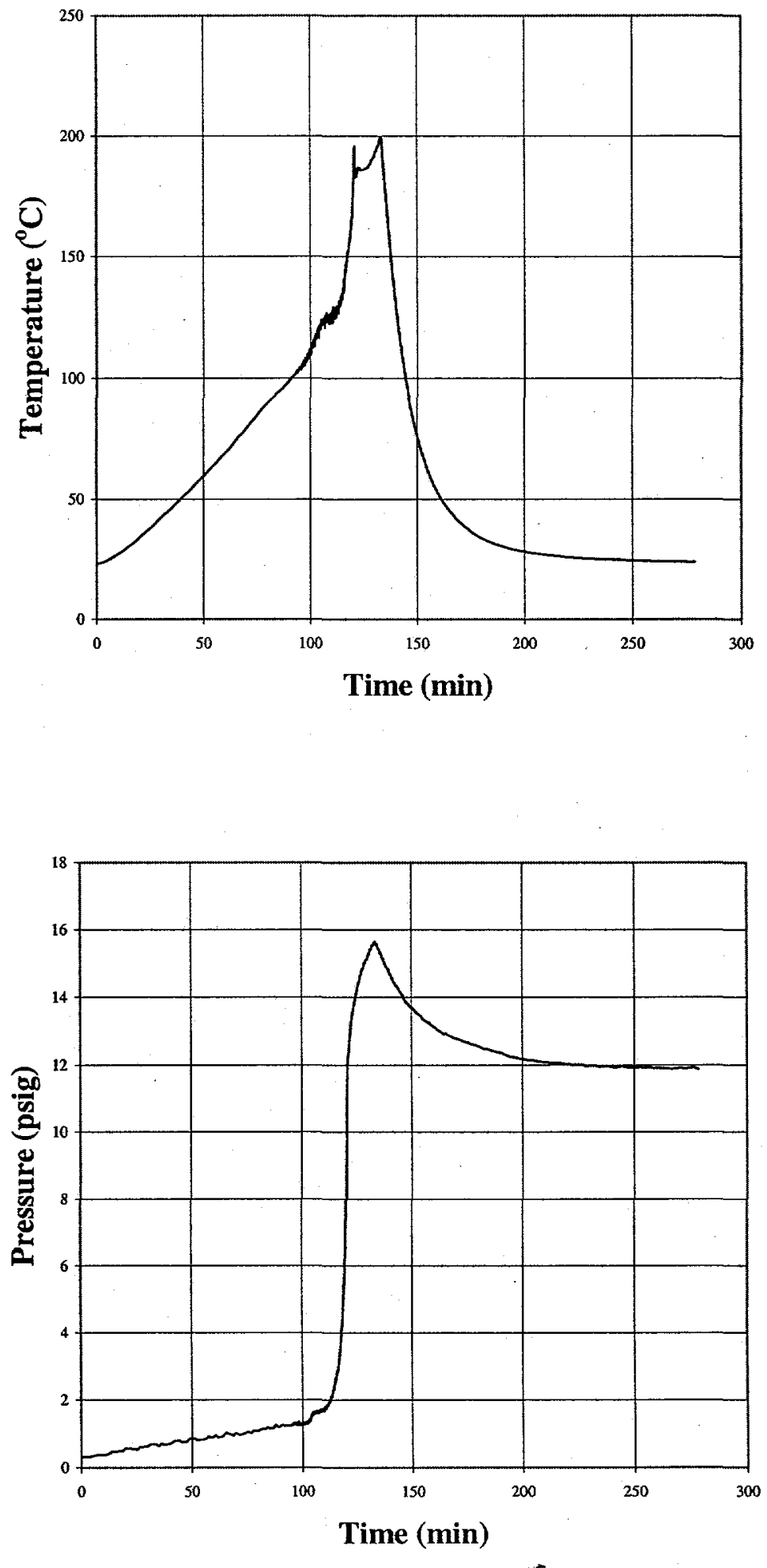
Figure D.24 Temperature and Pressure Profiles for Run No. TBP 10/9-1
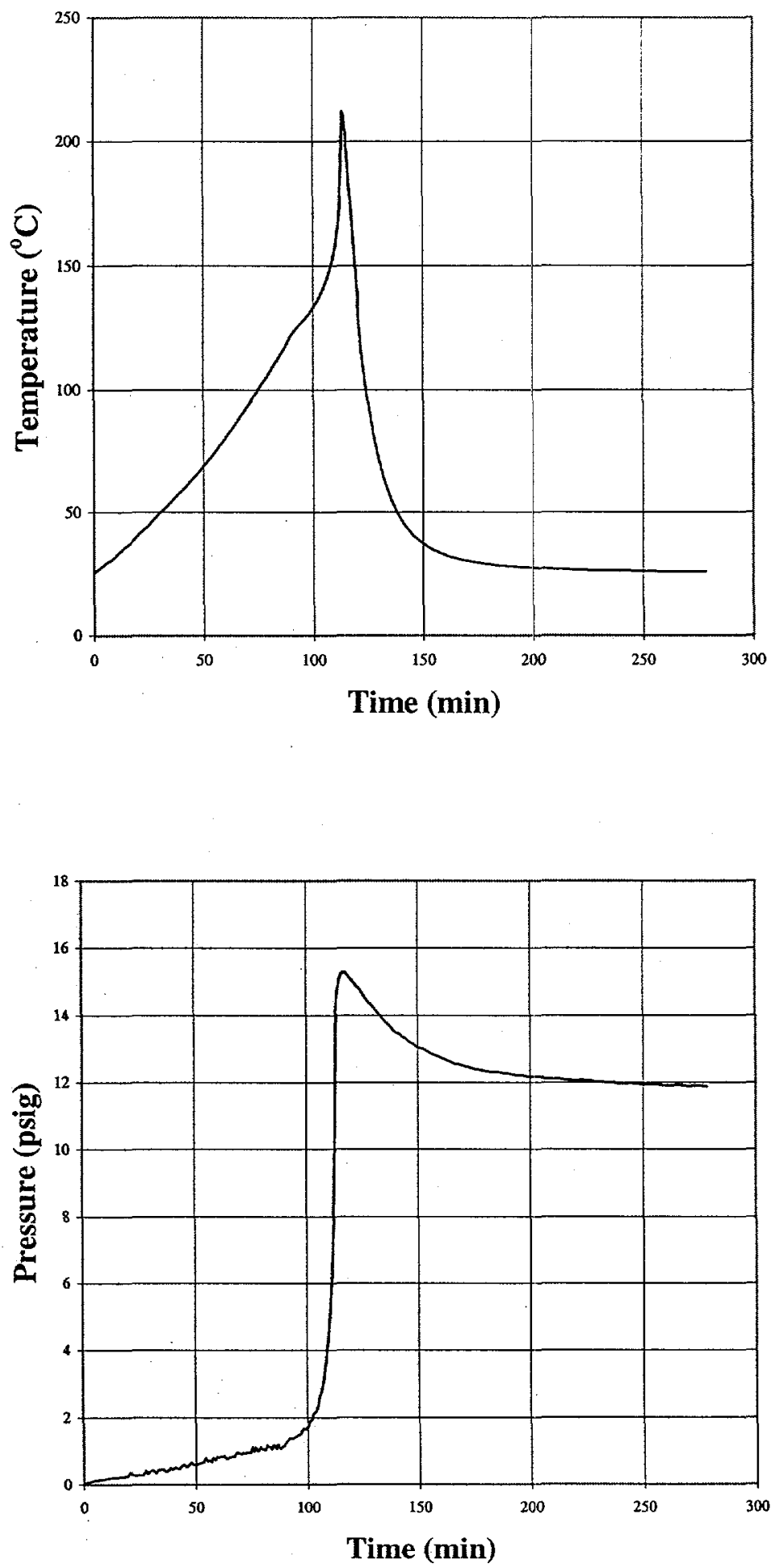
Figure D.25 Temperature and Pressure Profiles for Run No. TBP 10/10-1
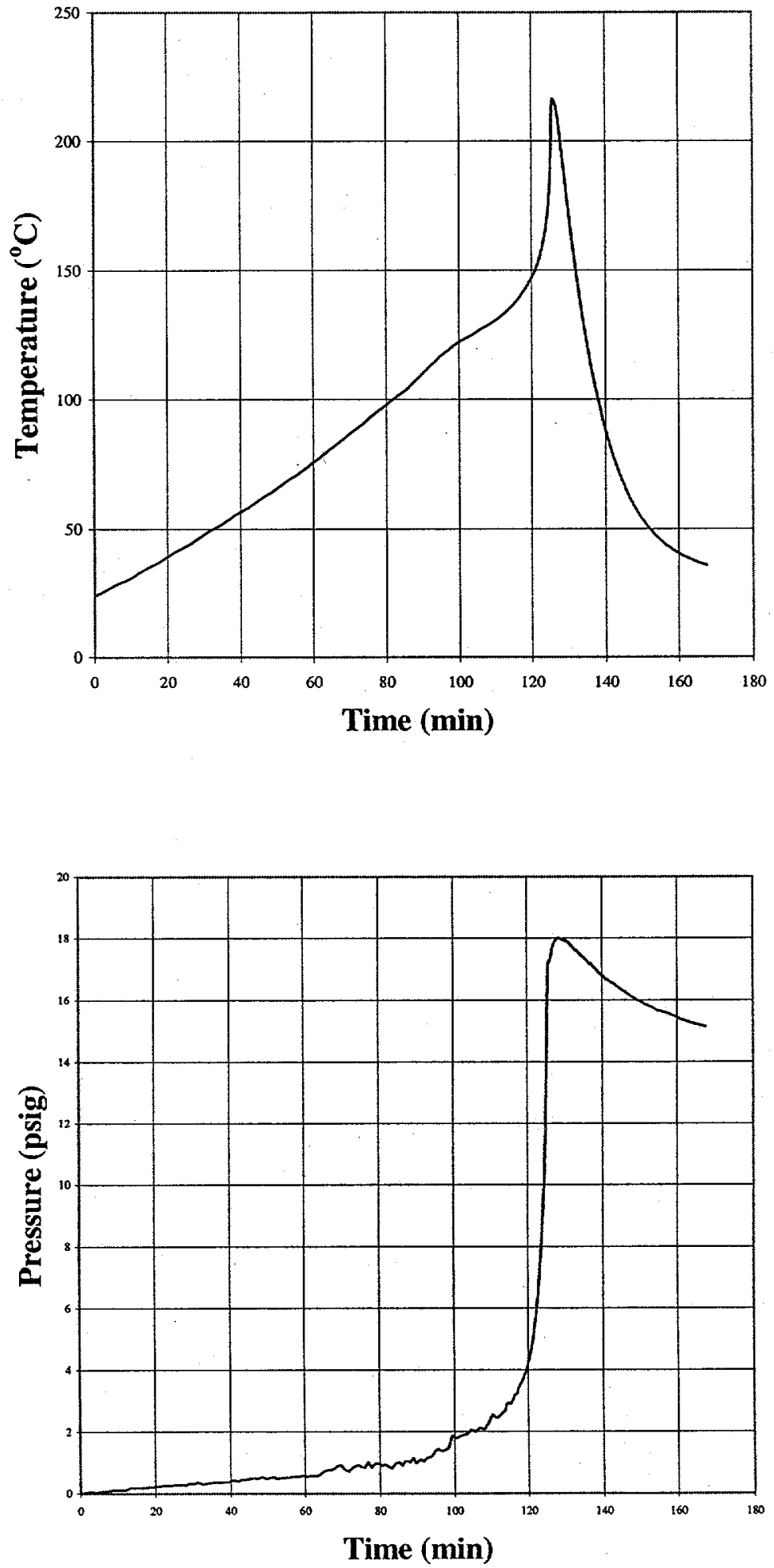
Figure D.26 Temperature and Pressure Profiles for Run No. TBP 10/10-2
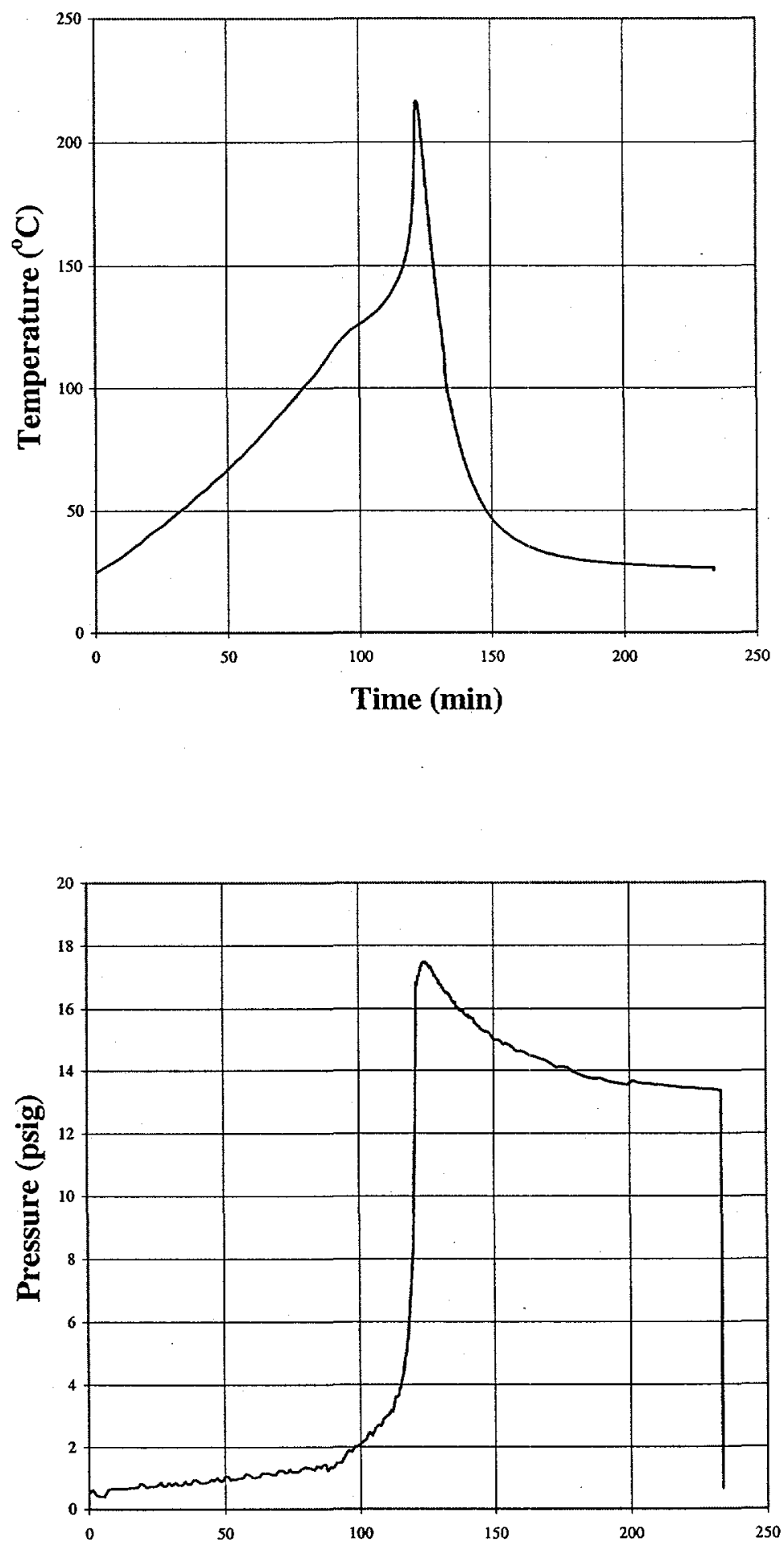

Time (min) 
Figure D.27 Temperature and Pressure Profiles for Run No. TBP 20/4-1

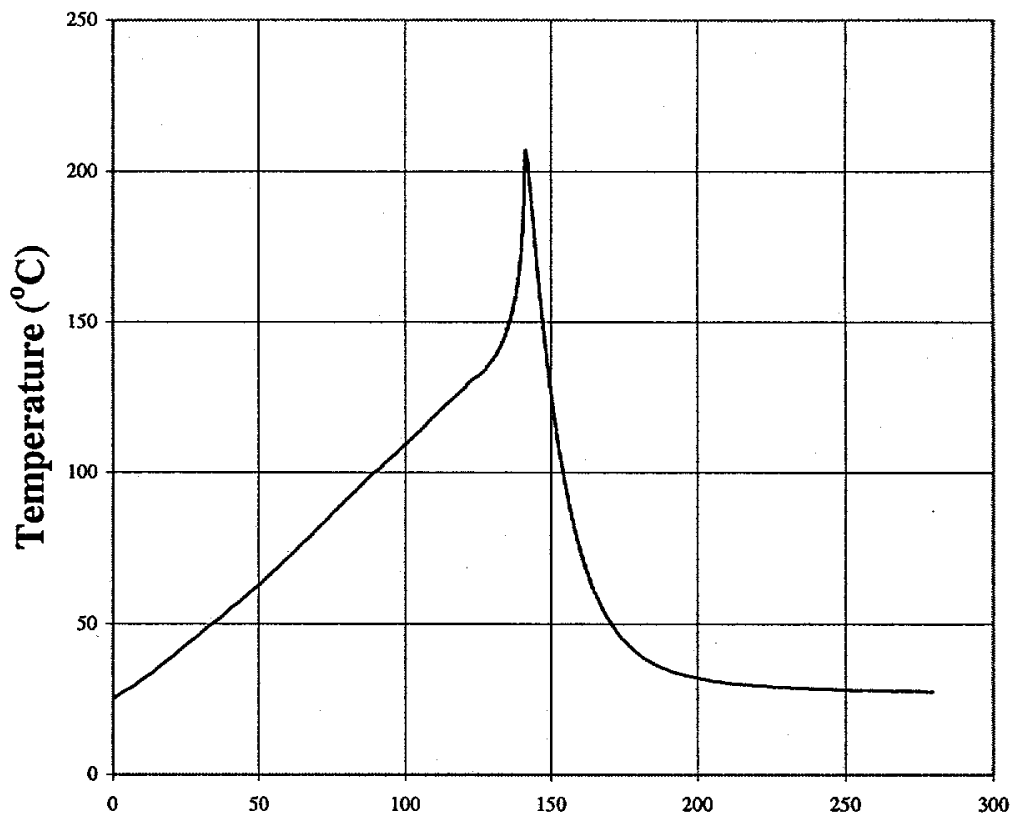

Time (min)

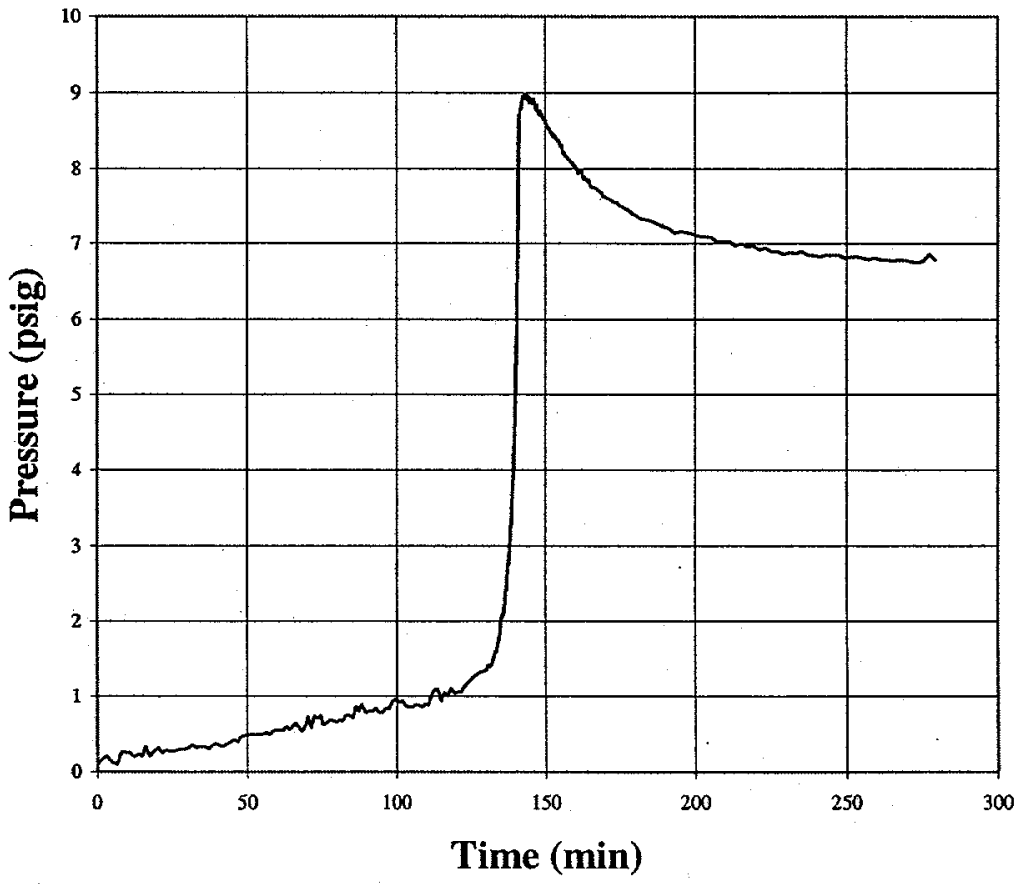


Figure D.28 Temperature and Pressure Profiles for Run No. TBP 20/4-2
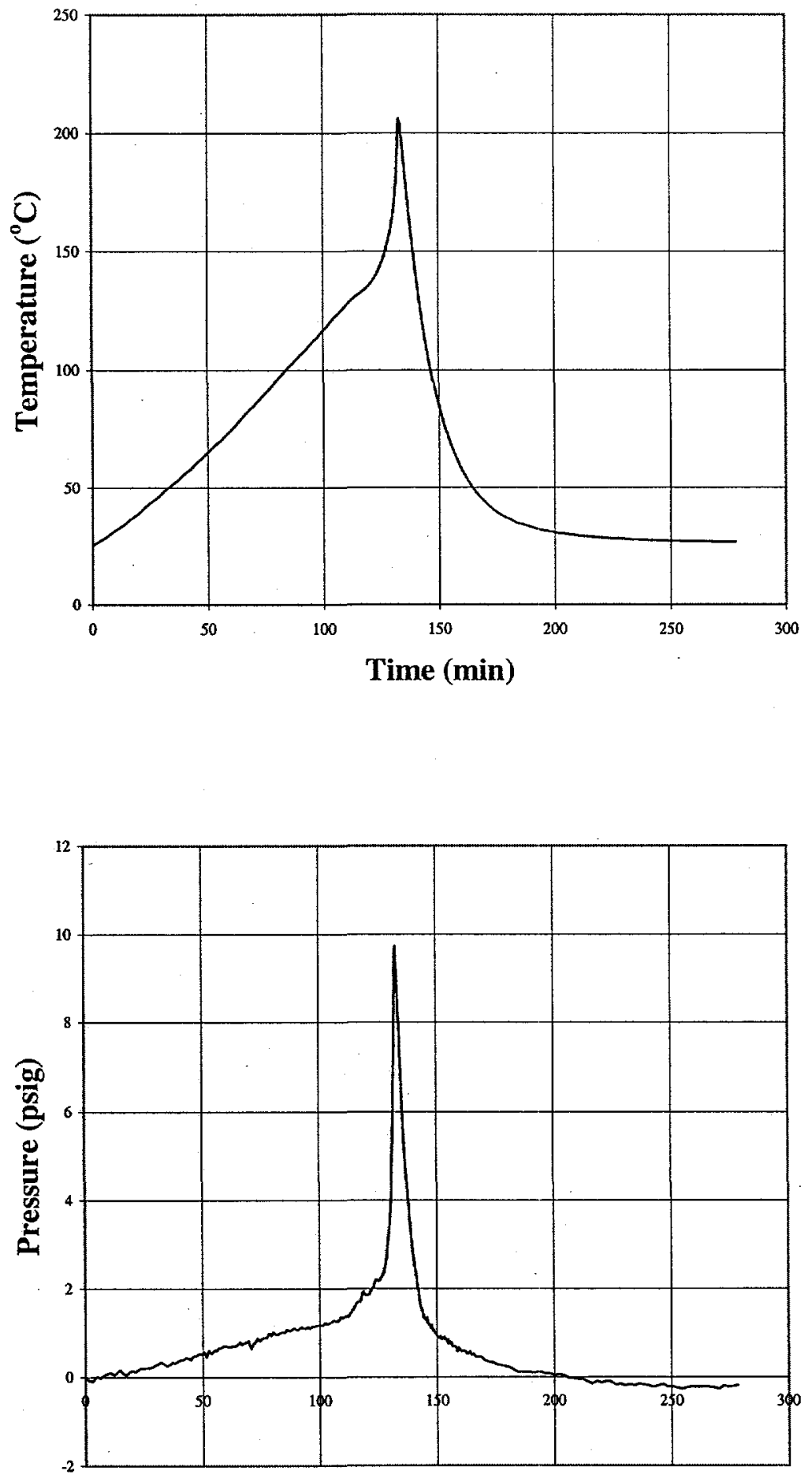

Time (min) 
Figure D.29 Temperature and Pressure Profiles for Run No. TBP 10/6-1

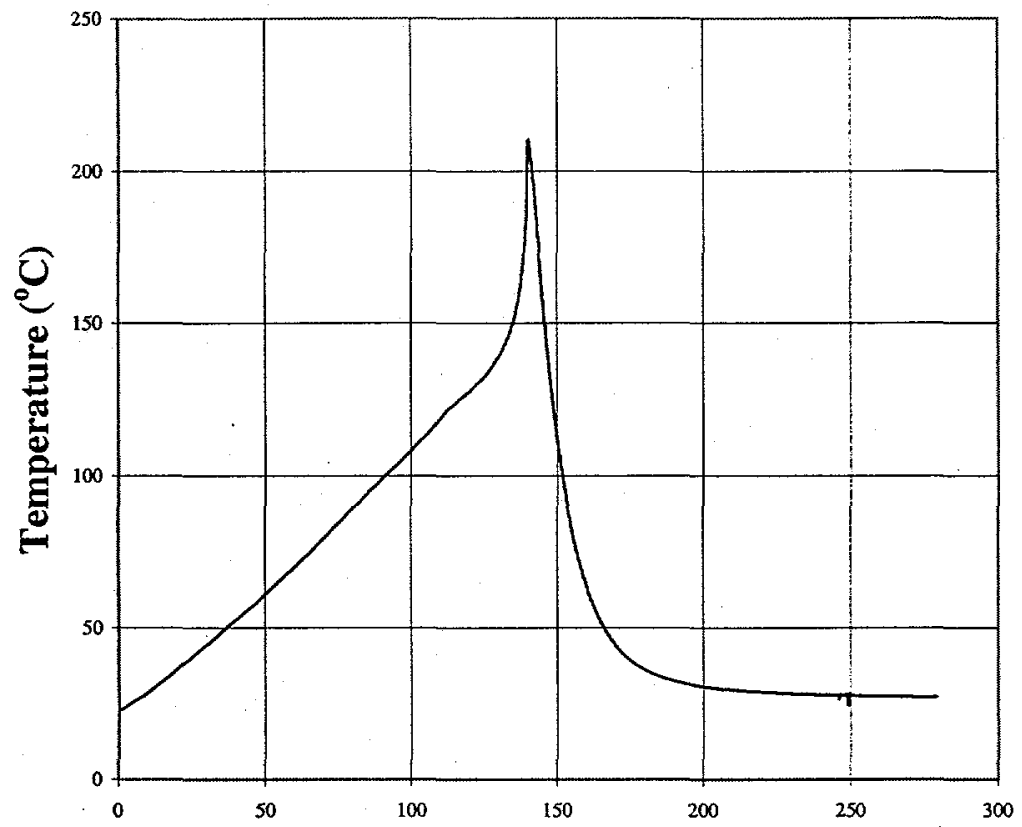

Time (min)

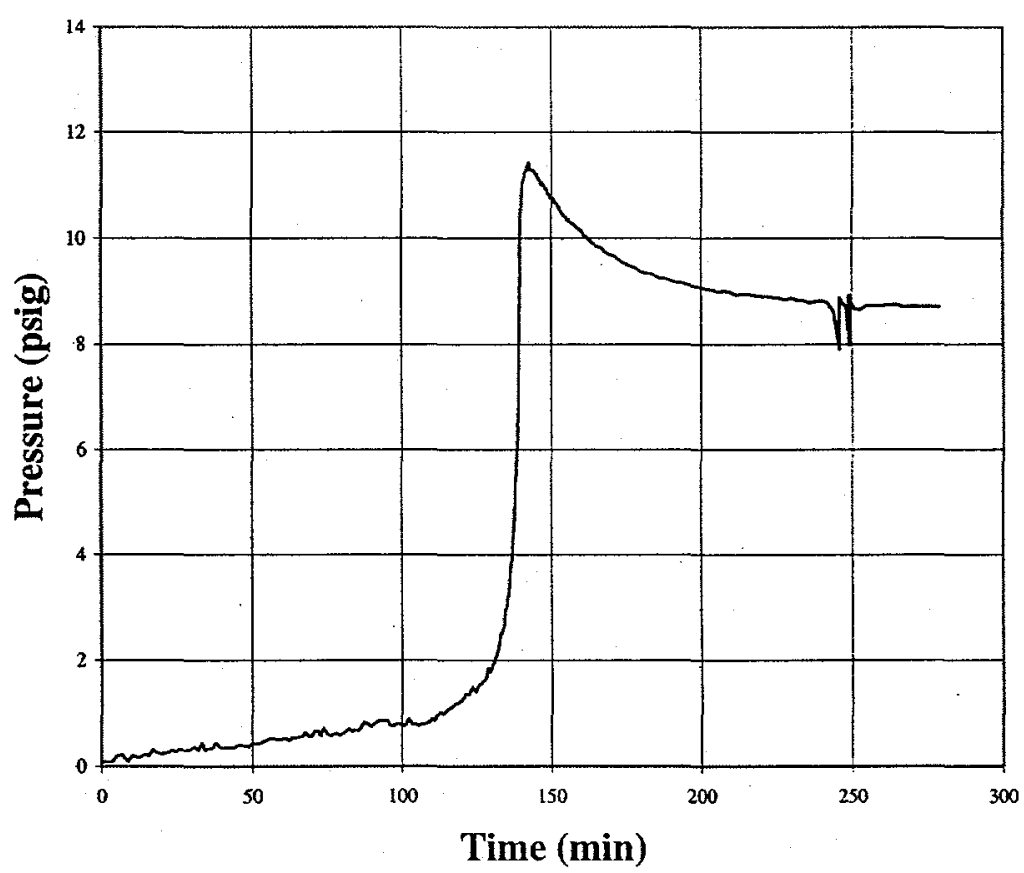


Figure D.30 Temperature and Pressure Profiles for Run No. TBP 10/6-2
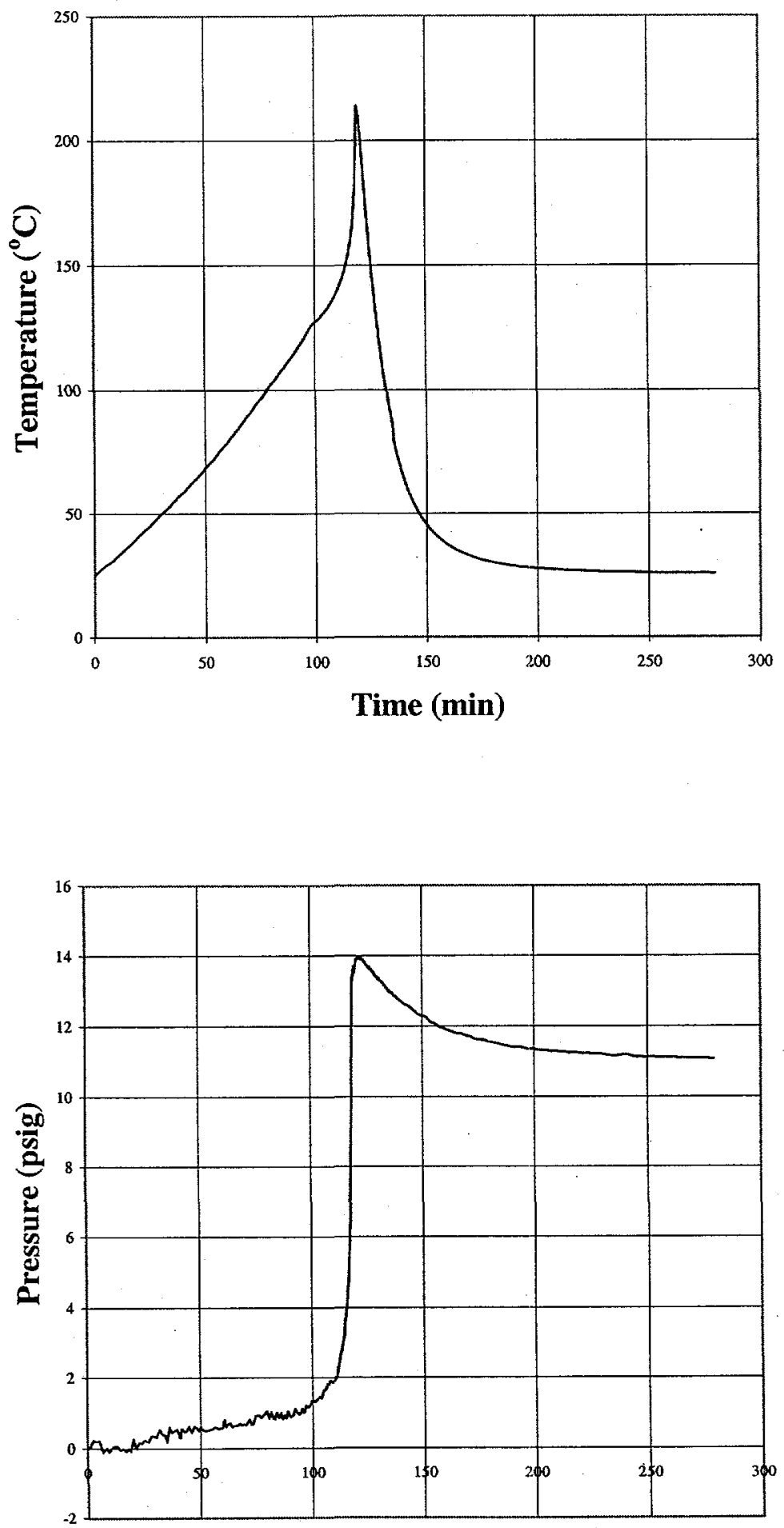

Time (min) 
Figure D.31 Temperature and Pressure Profiles for Run No. TBP 10/6-3
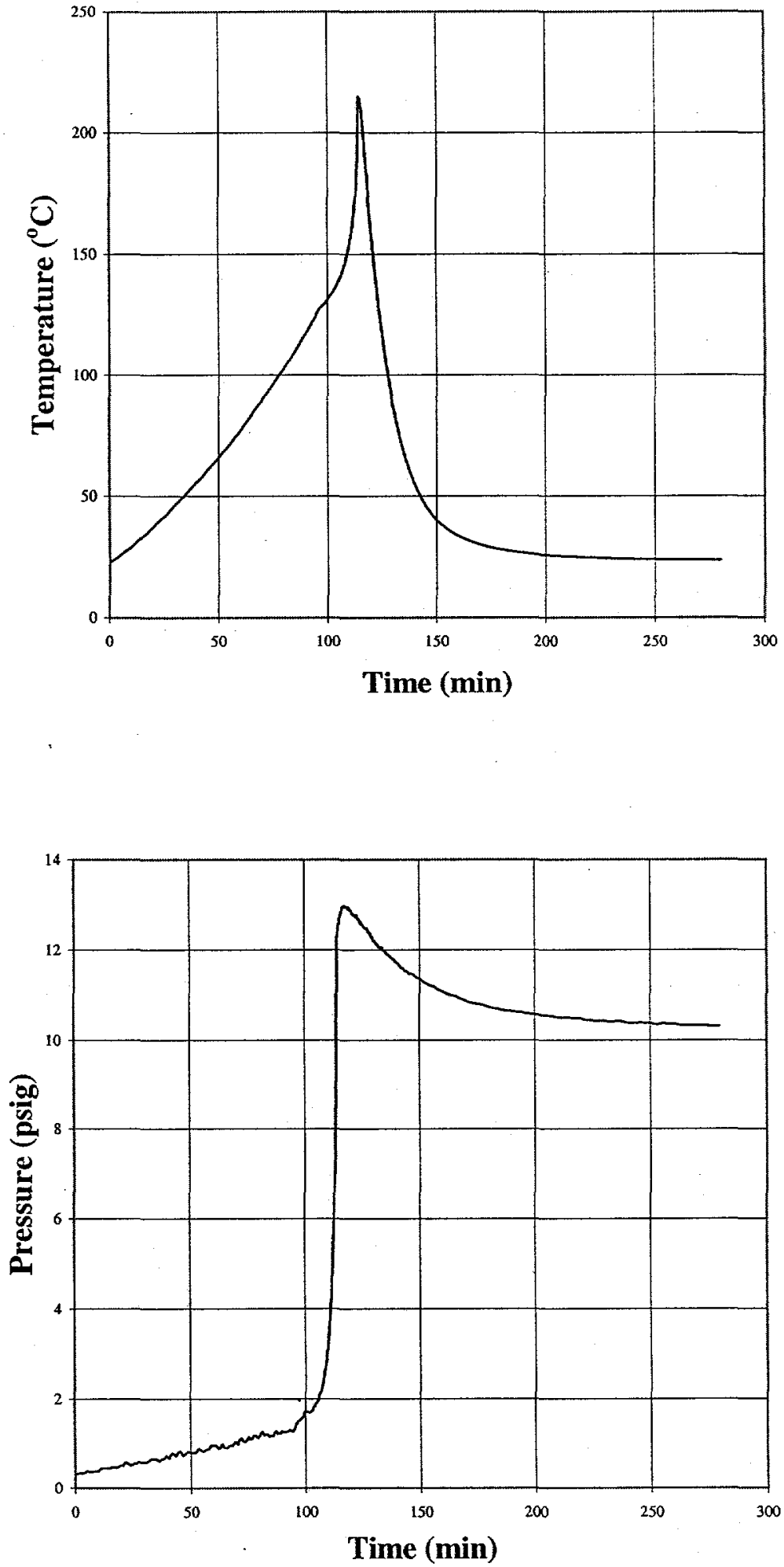
Figure D.32 Temperature and Pressure Profiles for Run No. TBP 20/7-1
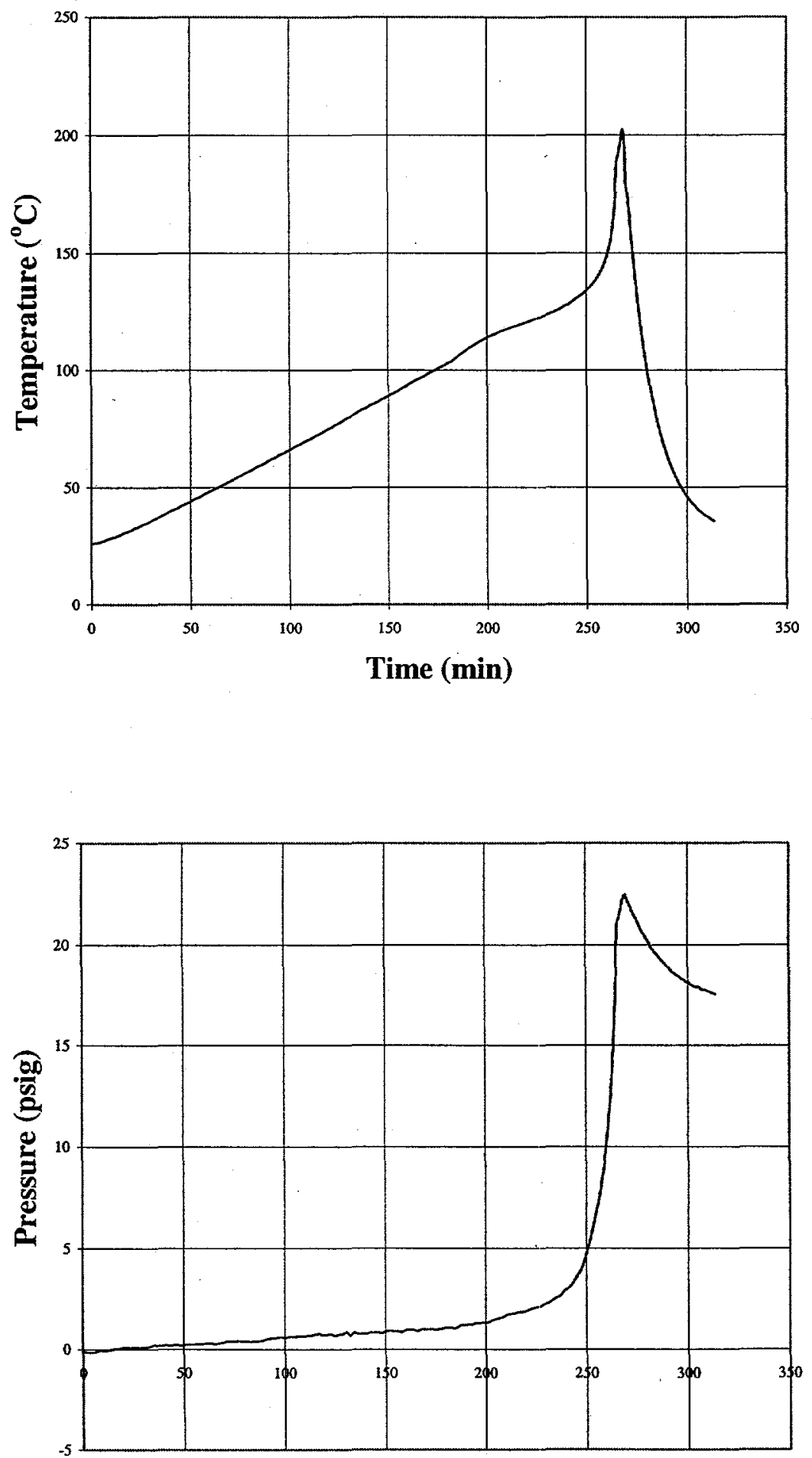

Time (min) 
Figure D.33 Temperature and Pressure Profiles for Run No. TBP 20/7-3
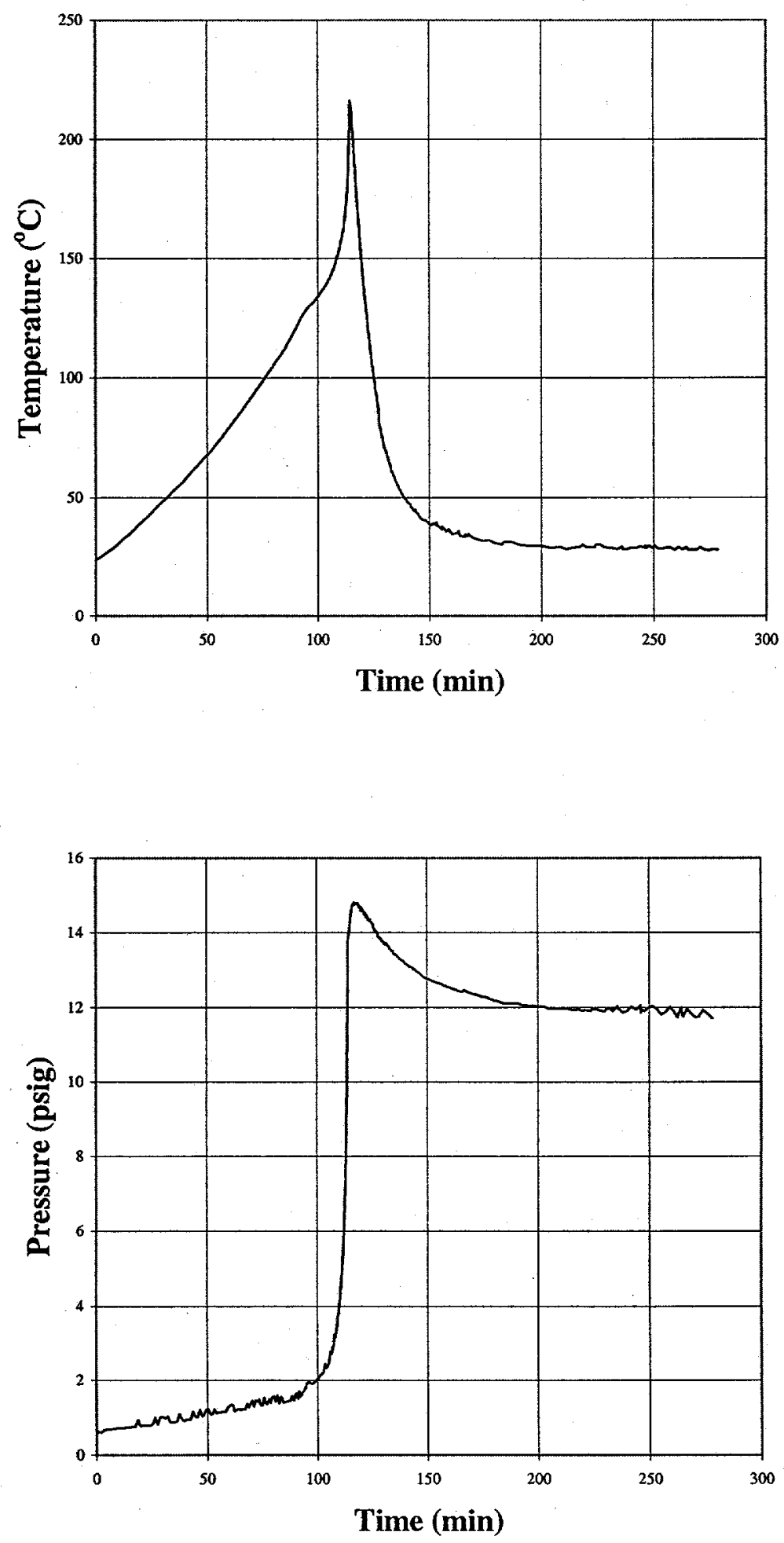
Figure D.34 Temperature and Pressure Profiles for Run No. TBP 20/8-1
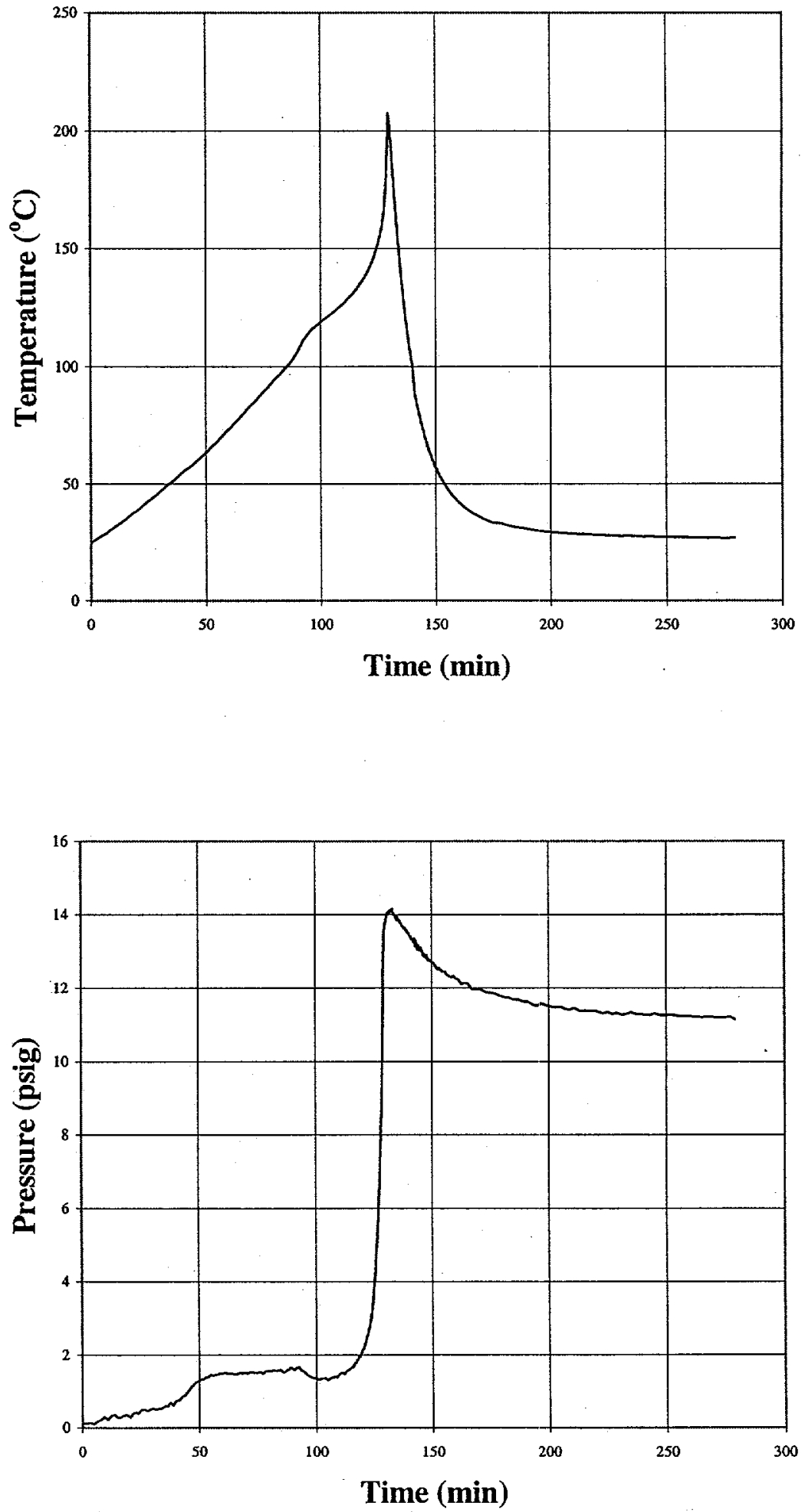
Figure D.35 Temperature and Pressure Profiles for Run No. TBP 20/7-4
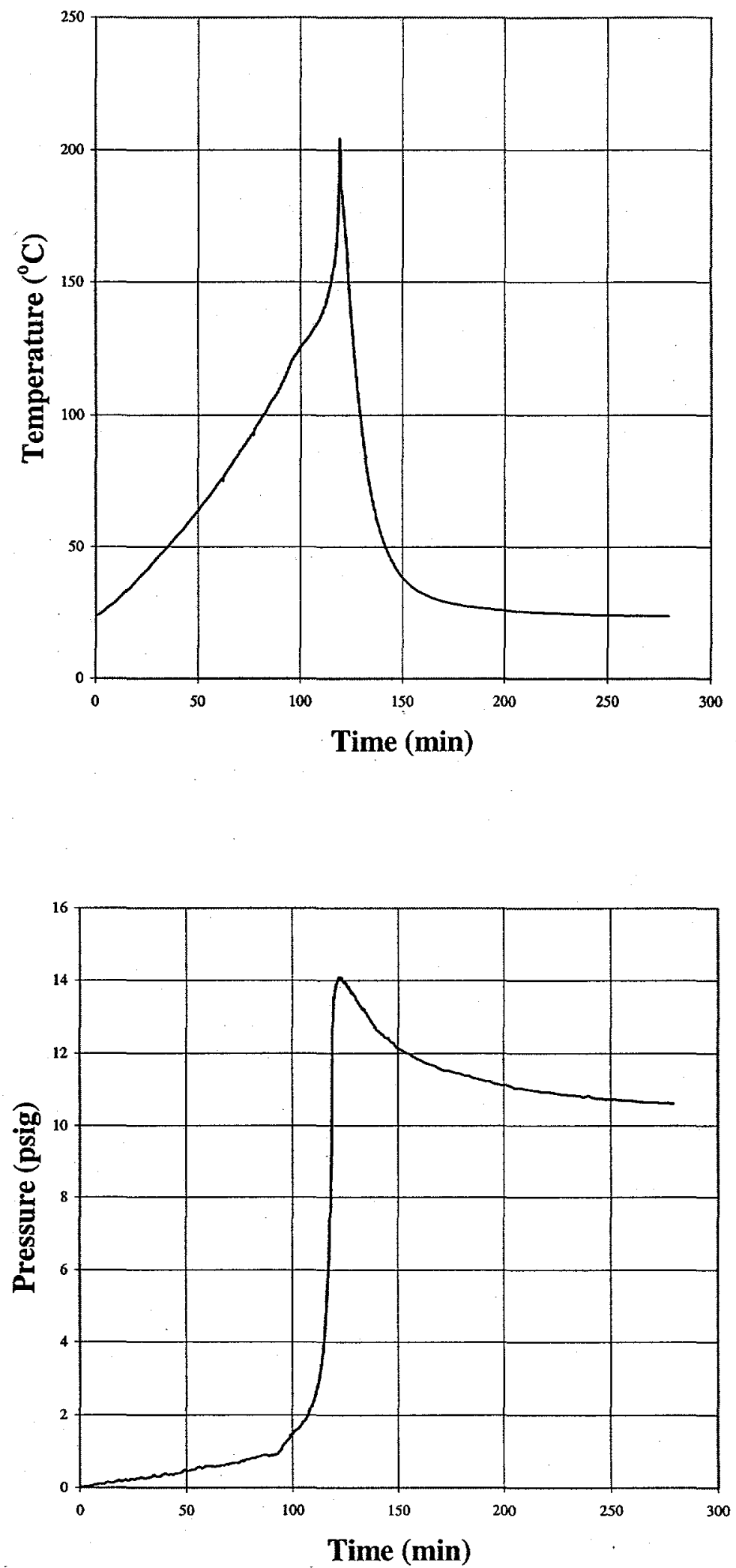
This page was intentionally left blank. 
WSRC-TR-2000-00427

Revision 0

\section{Appendix E Preparation of Solutions for Nitric Acid Extraction Measurements}

The target concentrations and the amounts of materials used to prepare the aqueous and organic phases used to measure the extraction of nitric acid into pure TBP are provided in Table E.1.

Table E.1 Preparation of Aqueous and Organic Phases for Nitric Acid Extraction Measurements

\begin{tabular}{|c|c|c|c|c|c|c|c|c|}
\hline \multirow[t]{2}{*}{ Run No. } & \multicolumn{2}{|c|}{ Target Concentrations } & \multirow{2}{*}{$\begin{array}{c}\mathrm{Al}\left(\mathrm{NO}_{3}\right)_{3} \cdot 9 \mathrm{H}_{2} \mathrm{O} \\
\text { Mass } \\
(\mathrm{g})\end{array}$} & \multirow{2}{*}{$\begin{array}{l}\text { Water } \\
\text { Mass } \\
(\mathrm{g})\end{array}$} & \multirow{2}{*}{$\begin{array}{c}\text { Nitric Acid } \\
\text { Mass } \\
\text { (g) }\end{array}$} & \multicolumn{2}{|c|}{ Actual Concentrations } & \multirow{2}{*}{$\begin{array}{l}\text { TBP } \\
\text { Mass } \\
\text { (g) }\end{array}$} \\
\hline & $\begin{array}{c}\text { Nitric Acid } \\
\text { (moles } / \mathrm{L})\end{array}$ & $\begin{array}{c}\mathrm{Al}\left(\mathrm{NO}_{3}\right)_{3} \\
(\mathrm{wt} \%)\end{array}$ & & & & $\begin{array}{c}\text { Nitric Acid } \\
(\text { moles } / \mathrm{L})\end{array}$ & $\begin{array}{c}\mathrm{Al}\left(\mathrm{NO}_{3}\right)_{3} \\
(\mathrm{wt} \%)\end{array}$ & \\
\hline TBPE $5 / 4$ & 4 & 5 & 2.630 & 17.833 & 9.243 & 4.00 & 5.03 & 4.688 \\
\hline TBPE $5 / 6$ & 6 & 5 & 2.765 & 14.679 & 13.876 & 6.00 & 5.01 & 4.598 \\
\hline TBPE $5 / 8$ & 8 & 5 & 2.891 & 11.398 & 18.501 & 8.00 & 5.01 & 4.694 \\
\hline TBPE $5 / 10$ & 10 & 5 & 3.019 & 8.020 & 23.113 & 9.99 & 5.02 & 4.708 \\
\hline TBPE $5 / 12$ & 12 & 5 & 3.116 & 4.460 & 27.737 & 12.00 & 5.01 & 4.675 \\
\hline TBPE $10 / 4$ & 4 & 10 & 5.530 & 16.573 & 9.249 & 4.00 & 10.01 & 4.674 \\
\hline TBPE $10 / 6$ & 6 & 10 & 5.820 & 13.367 & 13.861 & 5.99 & 10.00 & 4.685 \\
\hline TBPE $10 / 8$ & 8 & 10 & 6.092 & 10.029 & 18.481 & 7.99 & 10.00 & 4.698 \\
\hline TBPE $10 / 10$ & 10 & 10 & 6.346 & 6.564 & 23.108 & 10.00 & 10.00 & 4.675 \\
\hline TBPE $20 / 4$ & 4 & 20 & 12.418 & 13.613 & 9.254 & 4.00 & 19.98 & 4.673 \\
\hline TBPE 20/6 & 6 & 20 & 13.091 & 10.225 & 13.862 & 5.99 & 19.99 & 4.665 \\
\hline TBPE 20/8 & 8 & 20 & 13.705 & 6.730 & 18.493 & 8.00 & 19.99 & 4.670 \\
\hline
\end{tabular}


Free acid analyses were used to measure the amount of nitric acid extracted into pure TBP following contact with a series of nitric acid solutions containing 5, 10, and $20 \mathrm{wt} \% \mathrm{Al}\left(\mathrm{NO}_{3}\right)_{3}$. The actual concentrations of nitric acid and $\mathrm{Al}\left(\mathrm{NO}_{3}\right)_{3}$ in the aqueous phase and the concentration of nitric acid extracted into the TBP are provided in Table E.2.

Table E.2 Concentration of Nitric Acid Extracted into Pure TBP Contacted with Nitric $\operatorname{Acid} / \mathrm{Al}\left(\mathrm{NO}_{3}\right)_{3}$ Solutions

\begin{tabular}{|c|c|c|c|}
\hline \multirow[t]{2}{*}{ Experiment No. } & \multicolumn{2}{|c|}{ Aqueous Phase } & \multirow{2}{*}{$\begin{array}{c}\text { Organic Phase } \\
\text { Nitric Acid } \\
\text { (moles } / \mathrm{L} \text { ) }\end{array}$} \\
\hline & $\begin{array}{l}\text { Nitric Acid } \\
(\text { moles } / \mathrm{L})\end{array}$ & $\begin{array}{c}\mathrm{Al}\left(\mathrm{NO}_{3}\right)_{3} \\
(\mathrm{wt} \%)\end{array}$ & \\
\hline TBE 5/4-1 & 4.00 & 5.03 & 2.3484 \\
\hline TBE 5/4-2 & 4.00 & 5.03 & 2.2658 \\
\hline TBE 5/4-3 & 4.00 & 5.03 & 2.2930 \\
\hline TBPE 5/6-1 & 6.00 & 5.01 & 2.6862 \\
\hline TBPE 5/6-2 & 6.00 & 5.01 & 2.9042 \\
\hline TBPE 5/6-3 & 6.00 & 5.01 & 2.9470 \\
\hline TBPE 5/8-1 & 8.00 & 5.01 & 3.3696 \\
\hline TBPE 5/8-2 & 8.00 & 5.01 & 3.3013 \\
\hline TBPE 5/8-3 & 8.00 & 5.01 & 3.2319 \\
\hline TBPE 5/10-1 & 9.99 & 5.02 & 3.7953 \\
\hline TBPE 5/10-2 & 9.99 & 5.02 & 3.5708 \\
\hline TBPE 5/10-3 & 9.99 & 5.02 & 3.7174 \\
\hline TBPE 5/12-1 & 12.00 & 5.01 & 4.2390 \\
\hline TBPE 5/12-2 & 12.00 & 5.01 & 4.1739 \\
\hline TBPE 5/12-3 & 12.00 & 5.01 & 4.1656 \\
\hline TBPE 10/4-1 & 4.00 & 10.01 & 2.3893 \\
\hline TBPE 10/4-2 & 4.00 & 10.01 & 2.3652 \\
\hline TBPE $10 / 4-3$ & 4.00 & 10.01 & 2.4177 \\
\hline TBPE 10/6-1 & 5.99 & 10.00 & 2.8213 \\
\hline TBPE 10/6-2 & 5.99 & 10.00 & 2.8391 \\
\hline TBPE 10/6-3 & 5.99 & 10.00 & 2.8346 \\
\hline TBPE 10/8-1 & 7.99 & 10.00 & 3.2527 \\
\hline TBPE 10/8-2 & 7.99 & 10.00 & 3.2578 \\
\hline TBPE 10/8-3 & 7.99 & 10.00 & 3.1182 \\
\hline TBPE $10 / 10-1$ & 10.00 & 10.00 & 3.8084 \\
\hline TBPE 10/10-2 & 10.00 & 10.00 & 3.6243 \\
\hline TBPE $10 / 10-3$ & 10.00 & 10.00 & 3.7924 \\
\hline
\end{tabular}


WSRC-TR-2000-00427

Revision 0

Table E.2 Continued

\begin{tabular}{|c|c|c|c|}
\hline \multirow[t]{2}{*}{ Experiment No. } & \multicolumn{2}{|c|}{ Aqueous Phase } & \multirow{2}{*}{$\begin{array}{c}\text { Organic Phase } \\
\text { Nitric Acid } \\
\text { (moles } / \mathrm{L} \text { ) }\end{array}$} \\
\hline & $\begin{array}{c}\text { Nitric Acid } \\
\text { (moles/L) }\end{array}$ & $\begin{array}{c}\mathrm{Al}\left(\mathrm{NO}_{3}\right)_{3} \\
(\mathrm{wt} \%)\end{array}$ & \\
\hline TBPE 20/4-1 & 4.00 & 19.98 & 2.7991 \\
\hline TBPE 20/4-2 & 4.00 & 19.98 & 2.8033 \\
\hline TBPE 20/4-3 & 4.00 & 19.98 & 2.6780 \\
\hline TBPE 20/6-1 & $5: 99$ & 19.99 & 3.0584 \\
\hline TBPE 20/6-2 & 5.99 & 19.99 & 3.1797 \\
\hline TBPE 20/6-3 & 5.99 & 19.99 & 3.1835 \\
\hline TBPE 20/8-1 & 8.00 & 19.99 & 3.7436 \\
\hline TBPE 20/8-2 & 8.00 & 19.99 & 3.5822 \\
\hline TBPE 20/8-3 & 8.00 & 19.99 & 3.7816 \\
\hline
\end{tabular}

The average values for the nitric acid concentration in the organic phase for TBP contacted with aqueous phases containing $4.00,5.99$, and $8.00 \mathrm{M}$ nitric acid are $2.7601,3.1405$, and 3.7025M, respectively. 